\title{
Szymon Marcińczak
}

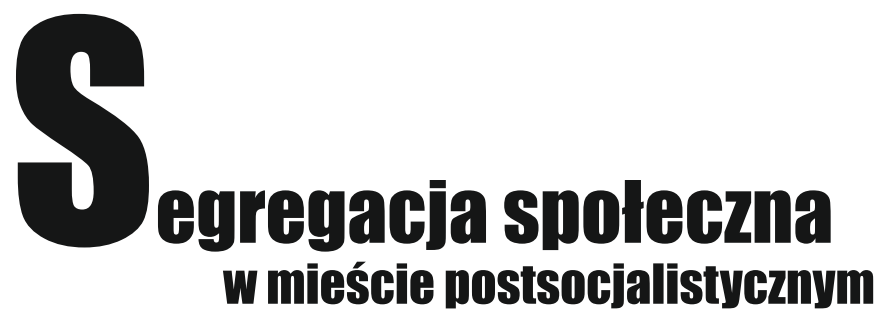

Bukareszt, Warszawa i Tallin na początku XXI wieku 
政 


\section{Szymon Marcińczak}

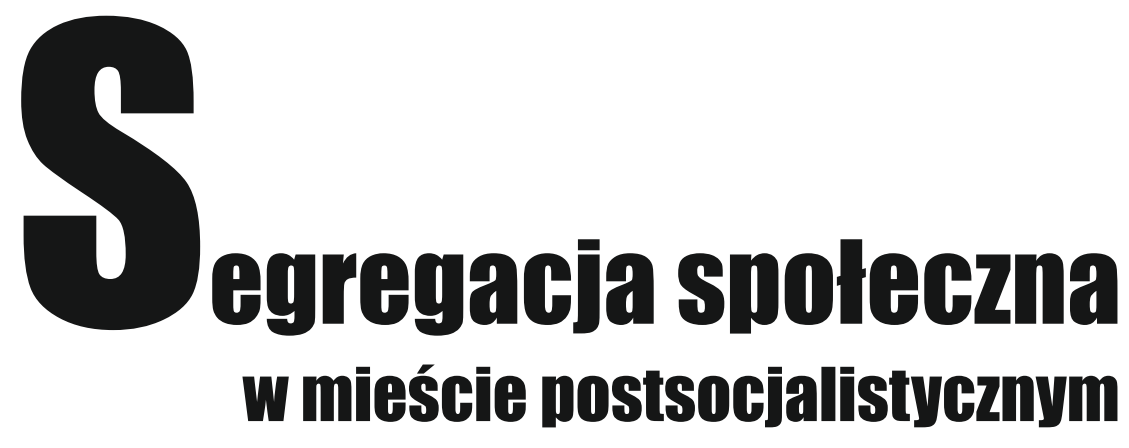

Bukareszt, Warszawa i Tallin na początku XXI wieku

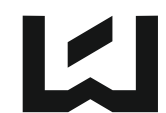

WYDAWNICTWO

UNIWERSYTETU

ŁÓDZKIEGO

ŁÓDŹ 2013 
Szymon Marcińczak - Zakład Urbanizacji Przestrzeni, Wydział Nauk Geograficznych Uniwersytet Łódzki, 90-232 Łódź, ul. Kopcińskiego 31

\author{
RECENZENT \\ Wiesław Maik \\ REDAKCJA TECHNICZNA, SKŁAD I ŁAMANIE \\ Agnieszka Ogrodowczyk \\ PROJEKT OKŁADKI \\ Agnieszka Ogrodowczyk
}

Wydrukowano z gotowych materiałów dostarczonych do Wydawnictwa UŁ

C Copyright by Uniwersytet Łódzki, Łódź 2013

Wydane przez Wydawnictwo Uniwersytetu Łódzkiego

Wydanie I. W.06258.13.0.H

ISBN (wersja drukowana) 978-83-7525-946-9

ISBN (ebook) 978-83-7969-254-5

Wydawnictwo Uniwersytetu Łódzkiego
90-131 Łódź, ul. Lindleya 8
www.wydawnictwo.uni.lodz.pl
e-mail: ksiegarnia@ uni.lodz.pl
tel. (42) 66558 63, faks (42) 6655862 


\section{Podziękowania}

Ksiażka ta nigdy by nie powstała, gdyby nie pomoc udzielona mi przez przyjaciót, z którymi miałem przyjemność i zaszczyt wspótpracować podczas badań nad przemianami spoleczno-przestrzennymi miast postsocjalistycznych. W tym miejscu chciatbym serdecznie podziękować dr Liviu Chelcea (Uniwersytet $w$ Bukareszcie), prof. Tiitowi Tammaru (Uniwersytet w Tartu) oraz dr Marcinowi Stepniakowi (Instytut Geografii i Przestrzennego Zagospodarowania, Polska Akademia Nauk), którzy udostepnili mi dane statystyczne wykorzystane w niniejszej pracy. Podziękowania należa się także prof. Michaelowi Gentile (Uniwersytet $w$ Umeå), za wspótprace $w$ badaniach nad segregacja $w$ miastach Europy Środkowo-Wschodniej przed i po upadku socjalizmu, ale także za to, że towarzyszyt mi w eksplorowaniu ,,dobrych" $i$,ztych” dzielnic miast postsocjalistycznych. Wspólne dyskusje „w terenie”, polegające na konfrontacji obecnego stanu wiedzy o segregacji społecznej z rzeczywistym obrazem podziałów społeczno-przestrzennych miast Poludnia, Centrum i Pótnocy bytego Bloku Wschodniego, pozwolity mi lepiej zrozumieć naturę nierówności społecznych i przestrzennych miast tej części Europy. Na zakończenie chciatbym podziękować mojej żonie, dr Agnieszce Ogrodowczyk (Uniwersytet Łódzki), za wsparcie i tolerowanie moich licznych wyjazdów w trakcie pracy nad ksiązką. 



\section{Rozdział 1}

\section{Wprowadzenie}

Trzy ostatnie dekady przyniosły zasadnicze zmiany w poglądach dotyczących roli i zakresu ingerencji państwa w redystrybucję dochodów, rozmiar świadczeń społecznych, a także w stymulację i kontrolę nad gospodarką. Zmiany te, obecnie o charakterze globalnym, swój początek miały w Stanach Zjednoczonych i Wielkiej Brytanii. Reformy gospodarcze zainicjowane i przeprowadzone przez Ronalda Reagana (Reaganomics) i Margaret Thatcher (Thatcherism) wyznaczyły nowy rozdział w rozwoju globalnego kapitalizmu. Cechami szczególnymi tych procesów w skali krajowej były znaczne ograniczenia wydatków publicznych w ramach państwa opiekuńczego, zmniejszenie podatków i deregulacja gospodarki. Odbyło się to przy akompaniamencie zmian w skali globalnej, które w głównej mierze polegały na wprowadzeniu ułatwień w międzynarodowym przepływie kapitału oraz otwarciu krajów rozwijających się na inwestycje zagraniczne. O ile efekty tych działań dotknęly w zasadzie każdej sfery życia społeczno-gospodarczego, w naukach społecznych przypuszczalnie najszerzej komentowanym tematem był, i nadal jest, gwałtowny wzrost nierówności społecznych i ekonomicznych w różnych skalach przestrzennych. Na poziomie międzynarodowym przejawia się on we wzroście zamożności państw bogatych i jeszcze większym ubożeniu państw biednych. Jednakże narastające rozwarstwienie $^{1}$ dotknęło także społeczeństwa wewnątrz granic państwowych (Sachs 2012, Stiglitz 2013).

Szczególną rolę, zarówno, jako kreator, jak i tworzywo, w procesie kształtowania nowego modelu gospodarki i społeczeństwa, pełnią wielkie miasta i regiony miejskie (Florida 2004). Dotyczy to przede wszystkim miast globalnych (Nowego Jorku, Londynu i Tokio), które stały się centrami kontroli i zarządzania międzynarodowym przepływem kapitału. Znajdując się w awangardzie przemian, ośrodki tego typu znakomicie oddają charakter nowych zróżnicowań społecznych - w szczególności polaryzacji społecznej wywołanej na skutek gwałtownego wzrostu nierówności w dochodach ludności (Sassen 1991). Stopniowa dualizacja dochodów mieszkańców prowadzi z kolei nieuchronnie do wzrostu segregacji społecznej i etnicznej (Mollenkopf i Castells 1992). Nowo powstałe

1 Podczas gdy w roku 1970 w Stanach Zjednoczonych stu najlepiej uposażonych dyrektorów zarabiało średnio 40 razy więcej niż przeciętny pracownik, w roku 2000 stosunek ten wzrósł do 1000 (Sachs 2012, 20-21). 
przeobrażenia struktur społecznych oraz ich materialny zapis w przestrzeni miasta wskazują zatem na silny związek pomiędzy skalą nierówności społecznych a poziomem segregacji społecznej (van Kempen 2007).

W dobie swobodnego przepływu ludności i kapitału los wielkich miast (a zatem także charakter i forma ich przemian społeczno-ekonomicznych i przestrzennych) równie silnie kształtowany jest przez unifikujący wpływ globalizacji, jak i przez szereg czynników lokalnych - począwszy od klimatu, a skończywszy na historycznie ukształtowanym profilu gospodarczym (Glaeser 2011).

Ponad dwadzieścia lat temu upadła żelazna kurtyna oddzielająca w Europie dawne kraje socjalistyczne od społecznych i ekonomicznych wpływów gospodarki kapitalistycznej. Tym samym te upadające i odcięte od reszty kapitalistycznego świata ostoje 'totalitarnego' państwa opiekuńczego (Sennett 2010) na dobre otworzyły się na nowe idee dotyczące roli sektora publicznego w kształtowaniu procesów społeczno-gospodarczych, jak również na napływ kapitału zagranicznego. W tym miejscu zaznaczyć należy, że natychmiastowe poddanie się 'terapii szokowej' - procesowi polegającemu na przyjęciu zasad demokracji parlamentarnej i wolnego rynku poprzez gwałtowną liberalizację i deregulację gospodarki oraz drastyczne ograniczenie osłon socjalnych - stanowiło niejednokrotnie kluczowy warunek otrzymania pomocy od międzynarodowych instytucji finansowych (Berend 2007).

Skala i tempo przemian nie były jednak wszędzie takie same. Przebieg i charakter procesu transformacji ustrojowej w dużej mierze odzwierciedla krajowe, regionalne i lokalne różnice, wynikające ze specyfiki długotrwale formowanego kontekstu społecznego, gospodarczego i przestrzennego (Pickles i Smith 1998, Carter i Maik 1999). Innymi słowy, wymiar i forma postsocjalistycznych przeobrażeń w krajach Europy Środkowej i Wschodniej zależne są nie tylko od skali działań rozpoczętych po 1989/1990 roku (w tym przede wszystkim od tempa liberalizacji gospodarki), ale też od dziedzictwa okresów presocjalistycznego i socjalistycznego.

Pomimo wszechobecnej dominacji państwa we wszystkich sferach życia codziennego oraz praktycznie całkowitej likwidacji sektora prywatnego, socjalistyczne kraje Europy Środkowej i Wschodniej wykazywały pewne różnice w naturze i funkcjonowaniu systemu społeczno-gospodarczego. Różnice te uległy dalszemu pogłębieniu w latach 1980., gdy w regionie występowały jakże odmienne oblicza socjalizmu, sytuujące się pomiędzy stalinowskimi reżimami Nicolae Ceauşescu w Rumuni, czy Envera Hodży w Albanii, a gulaszowym socjalizmem na Węgrzech, gdzie gospodarka przestała być centralnie sterowana już w 1986 roku. Na zróżnicowania te nałożyły się dramatyczne zmiany, zainicjowane we wczesnych latach 1990. Odrębne trajektorie rozwoju przed, ale 
przede wszystkim po 1989 roku, dały podstawę dla nowego podziału krajów położonych na wschód od byłej żelaznej kurtyny, które w okresie socjalistycznym określano ogólnie, jako „Europa Wschodnia” (French i Hamilton 1979). Według Hamiltona i innych (2005, s. 7-11) obszar postsocjalistycznej Europy podzielić można na cztery regiony:

1) Europę Środkową (Czechy, Polska, Słowacja, Słowenia i Węgry);

2) kraje Bałtyckie (Estonia, Litwa i Łotwa);

3) Europę Południowo-Wschodnią (republiki byłej Jugosławii oprócz Słowenii, Albania, Bułgaria i Rumunia);

4) Europę Wschodnią: (europejska część Rosji, Białoruś, Mołdawia i Ukraina).

Pomimo generalnego charakteru, klasyfikacja ta jest spójna przestrzennie i dobrze oddaje tempo przemian po upadku socjalizmu. W skrócie, w pierwszej dekadzie po 1990 roku, najwyższy stopień zaawansowania transformacji ustrojowej cechował kraje grupy pierwszej (Europa Środkowa) i zasadniczo malał wraz z kolejnością wyróżnionych grup, aż do praktycznie zupełnego braku jakichkolwiek zmian w niektórych krajach Europy Wschodniej (Deacon 2000).

Bez względu na położenie w ramach byłego bloku wschodniego, okres zmian systemowych przyniósł nagły wzrost nierówności społeczno-ekonomicznych w skali regionalnej i lokalnej. Podział na „zwycięzców” i „przegranych” w procesie transformacji ustrojowej odnosi się nie tylko do określonych grup społecznych, których znaczenie wzrosło lub zmalało po 1990 roku, ale także do poszczególnych regionów w ramach państw postsocjalistycznych, których tempo rozwoju przyspieszyło lub zwolniło (Bhalla i Lapeyre 2004, Węcławowicz 2004). Chociaż różnice w poziomie rozwoju regionalnego były czytelne w krajach socjalistycznych (Fuchs i Demko 1978), upadek socjalizmu tylko je uwypuklił (Dunford i Smith 2000).

Od wczesnych lat 1990. najszybsze zmiany społeczne i gospodarcze cechowały wielkie miasta dawnej Europy Wschodniej. Wśród tej grupy miast w awangardzie procesu transformacji ustrojowej bezsprzecznie znajdowały się stolice europejskich krajów postsocjalistycznych (Stenning 2004). Zaznaczyć jednak należy, że i w tym zbiorze miast poziom zaawansowania ewolucji struktur społeczno-ekonomicznych i przestrzennych nie jest jednakowy. Za liderów uważane są zazwyczaj Budapeszt, Praga i Warszawa (Węcławowicz 1998, Tasan-Kok 2007). Nieco później na ścieżkę szybkiego rozwoju weszły Ryga, Wilno i Tallin (Tosics 2005). W Europie Południowo-Wschodniej głębsze zmiany systemowe nastąpiły dopiero w drugiej połowie lat 1990., lokując tamtejsze miasta w głównym nurcie transformacji ustrojowej z prawie dziesięcioletnim opóźnieniem (Tsenkova 2007). 
Mimo czytelnej segmentacji na rynku pracy, która pociągała za sobą zróżnicowany dostęp do ograniczonych przywilejów i dóbr materialnych (Szelényi 1978), w byłych krajach socjalistycznych poziom nierówności w dochodach ludności był niższy niż w innych systemach politycznych i gospodarczych na podobnym poziomie rozwoju przemysłowego (Heyns 2005). Bardzo niskie rozwarstwienie $\mathrm{w}$ dochodach społeczeństwa socjalistyczne zawdzięczały ścisłej kontroli wynagrodzeń w zasadzie we wszystkich działach gospodarki oraz ekstensywnemu, całkowicie kontrolowanemu przez państwo i bazującemu na miejscu pracy systemowi świadczeń społecznych (Cerami 2010), w tym również mieszkań (Domański 1997, Gentile i Sjöberg 2010).

Pierwsza dekada transformacji ustrojowej zakończyła się w zupełnie innych realiach społeczno-ekonomicznych, gdyż rozwój wolnego rynku wymusił uwolnienie cen i wynagrodzeń. Pomimo początkowego zachowania status quo w pierwszych latach po upadku socjalizmu, głównie w celu zapobieżenia rozruchom społecznym, w drugiej połowie lat 1990. zakres świadczeń społecznych skurczył się gwałtownie (Rashid i inni 2005). Nieskrępowany rozwój wolnego rynku, szybka globalizacja społeczeństw i gospodarek oraz nieuchronny upadek rozdętego państwa opiekuńczego uwypukliły społeczną cenę zmiany systemu. Następstwem szybkiego rozwoju gospodarczego było pojawienie się długotrwałego bezrobocia, często o charakterze strukturalnym, zmniejszanie się partycypacji na rynku pracy, a także wzrost tymczasowości zatrudnienia oraz wycofywanie się państwa z roli gwaranta wielu zabezpieczeń społecznych (Hörschelmann 2004, Smith i inni 2008, Stenning i inni 2010). Na zmiany te nałożyła się gwałtowna tertiaryzacja (serwicyzacja) gospodarki, co w połączeniu z innymi aspektami zmian doprowadziło najpierw do nowej segmentacji na rynku pracy, a w rezultacie do raptownego wzrostu nierówności społecznych mierzonych uzyskiwanym dochodem (Bandelj i Mahutga 2010) oraz nowej stratyfikacji społeczno-zawodowej (Rashid i inni 2005). W Polsce (Domański 2004, Węcławowicz 2004) i w innych krajach regionu (Cerami 2010) główne przetasowania w hierarchii społecznej dopełniły się do roku 2000. Wyłoniła się z nich niezbyt liczna elita oraz znacznie większa grupa kategorii społeczno-zawodowych, które musiały pogodzić się z utratą przywilejów i zmniejszeniem realnych dochodów.

Tempo i skala zmian społecznych, wywołanych radykalnym wzrostem nierówności w dochodach mieszkańców państw postsocjalistycznych, wskazują na silny związek nie tylko z zakresem zaaplikowanej „terapii szokowej”, ale też z dynamiką wzrostu gospodarczego w skali regionalnej (Carter i Maik 1999). W wielkich miastach, a przede wszystkim w metropoliach, poziom rozwarstwienia społecznego był najwyższy i rósł najszybciej (Brzeziński i Kostro 2010, Marek 2011). Zakładając, że metropolie są specyficznym miejscem, w którym 
dochodzi do „spotkania” pomiędzy jednostkami a instytucjami społecznymi (Maik 2003), przyjąć można, że w miastach, w których procesy globalizacji i neoliberalnych zmian w funkcjonowaniu społeczeństwa i gospodarki sięgnęły najgłębiej, przemiany struktury społecznej trwały najkrócej.

Biorąc pod uwagę rozmach zmian i towarzyszący im szereg negatywnych efektów w sferze społecznej i gospodarczej, już w połowie lat 1990. zaczęto w literaturze przedmiotu stosować do opisu wyłaniających się wzorów i konsekwencji nowych nierówności następujące terminy: „wykluczenie społeczne”, „gettoizacja” czy „polaryzacja społeczna” (Węcławowicz 1998, Kovács 1998, Sýkora 1999). Pomimo wzrastającego zainteresowania tematem, zaskakującym, ale niestety prawdziwym wydaje się być stwierdzenie, że wielkie europejskie miasta postsocjalistyczne, a zwłaszcza dotyczące ich problemy przestrzennej manifestacji nowych podziałów na tle społeczno-ekonomicznym, wciąż znajdują się poza głównym nurtem systematycznych badań empirycznych (Stanilov 2007). Równolegle głoszony jest pogląd, że z uwagi na szczególną rolę w procesie transformacji ustrojowej, wielkie miasta postsocjalistyczne stanowią znakomite „laboratorium” do studiowania związków pomiędzy nowo powstającym porządkiem społecznym a wytwarzaną przezeń przestrzenią (Stenning 2004).

Pomimo upływu ponad 20 lat od upadku poprzedniego systemu wciąż brakuje prac, które prezentowałyby systematyczne ujęcie zjawiska segregacji społecznej w mieście postsocjalistycznym. Innymi słowy, o ile w literaturze dostępne są liczne prace o miastach Europy Północnej, Południowej i Zachodniej (Wessel 2000, Malheiros 2002, Musterd 2005, Andersson 2006, Arapoglou i Sayas 2009, Musterd i Van Kempen 2009, Van Kempen i Murie 2009), obszar dawnych państw socjalistycznych nadal w znacznej mierze pozostaje białą plamą na mapie segregacji społecznej na starym kontynencie (Musterd 2005, Sýkora 2009, Marcińczak 2012). Oprócz odpowiedzi na pytania dotyczące skali i natury zjawiska segregacji w mieście postsocjalistycznym, prace na ten temat pozwoliłyby także na nawiązanie do badań nad wpływem neoliberalnych zmian w globalnym kapitalizmie na materialny zapis rosnących nierówności w przestrzeniach miast po obu stronach Atlantyku. Co ważniejsze, wyniki pochodzące z miast reprezentujących państwa o odmiennym stopniu zaawansowania i specyfice transformacji minionego ustroju, umożliwiłyby lepsze zrozumienie związków pomiędzy tempem i charakterem przemian systemowych a rozmiarem nierówności społecznych i poziomem segregacji.

W pracy postawiono hipotezę badawczą, że wyższy poziom nierówności społecznych, szybsza globalizacja gospodarki i społeczeństwa oraz większe zaawansowanie i charakter zmian społecznych, politycznych i gospodarczych po upadku socjalizmu oznaczać także będą wyższy poziom segregacji społecznej. 
Podstawowym celem rozprawy jest zatem analiza skali i wzorów przestrzennych segregacji społecznej w mieście postsocjalistycznym. Według Stownika wspótczesnego języka polskiego (1996), termin ,segregacja” posiada dwa znaczenia: 1) potoczne, które oznacza podział na jednorodne grupy, kategorie według określonych kryteriów, klasyfikacje, segregowania lub porządkowanie; 2) naukowe, socjologiczne oznaczające izolowanie jednych grup ludzkich od drugich w ramach jednego społeczeństwa na podstawie wcześniej ustalonych kryteriów (np. etnicznych, rasowych), często wynikające z irracjonalnych przesłanek (np. segregacja rasowa, religijna itp.). W literaturze przedmiotu termin „segregacja społeczna" w sposób ogólny definiowany bywa jako nierównomierność w rozmieszczeniu przestrzennym grup ludności o różnym statusie społeczno-materialnym (Musterd 2005). Biorąc pod uwagę, że wzrost nierówności społecznych po 1990 roku jest niepodważalnym faktem ${ }^{2}$, precyzyjne ustalenie rozmiaru segregacji i lokalnych form koncentracji społeczno-przestrzennej pozwoli na dokładniejsze poznanie relacji pomiędzy nowymi podziałami społecznymi i ich manifestacją w przestrzeni. Ponadto, zastosowany w pracy zestaw narzędzi badawczych pozwala na bezpośrednie nawiązanie dialogu ze studiami prowadzonymi w innych częściach Europy, a stąd też na ustalenie odpowiedzi na pytanie dotyczące stopnia „polaryzacji” społecznej i przestrzennej w wielkim mieście dawnego bloku wschodniego.

Wyniki empiryczne ilustrują poziom i wzory przestrzenne segregacji społecznej w trzech stolicach krajów postsocjalistycznych: Bukareszcie, Tallinie i Warszawie. O ile dobór miast nie wyczerpuje całej palety barw i odcieni transformacji ustrojowej w byłych państwach socjalistycznych, miasta te reprezentują najważniejsze ośrodki trzech głównych subregionów dawnej Europy Wschodniej, w których proces zmiany systemu politycznego, społecznego i gospodarczego rozpoczął się w odmiennych warunkach oraz przebiegał w różnym tempie. Cechą wspólną tych krajów jest natomiast symboliczny fakt zakończenia transformacji ustrojowej, którego zwieńczeniem było wstąpienie do Unii Europejskiej w pierwszej dekadzie XXI wieku. Analiza zjawiska segregacji społecz-

${ }^{2}$ Dostępne dane wskazują na wyraźny wzrost nierówności społecznych, mierzonych nierównomiernością w rozkładzie dochodów. Standardowa miara nierówności społecznych (indeks Giniego) wskazywała na szybki wzrost we wszystkich byłych krajach socjalistycznych. Jednak tempo wzrostu i skala nierówności nie wszędzie były takie same. W okresie od 1989 do 2002 roku, w Polsce miara ta wzrosła od 26 do 35, w Rumunii od 23 do 32, w Estonii od 23 do 37, a w Czechach od 18 do 26 (Index Mundi 2013). Dla przykładu, na początku XXI wieku, poziom nierówności społecznych w Stanach Zjednoczonych wynosił 45, w Wielkiej Brytanii 34, a w Szwecji, kraju znanym z silnego państwa opiekuńczego, jedynie 23 (ibid.). 
nej w miastach, które cechują odmienne profile rozwoju społeczno-gospodarczego przed, w trakcie i po okresie socjalistycznym, pozwoli na poszerzenie zakresu wiedzy o wpływie transformacji ustrojowej na poziom i geografię segregacji społecznej po socjalizmie.

Podstawowy materiał badawczy stanowią wyniki spisów powszechnych, przeprowadzonych w 2000 roku w Estonii oraz w 2002 roku w Polsce i Rumunii. Zakres czasowy wykorzystanych danych statystycznych, obejmujący początek lat 2000., związany jest z faktem, iż zasadniczy etap przejścia od socjalizmu do gospodarki rynkowej funkcjonującej w warunkach demokracji parlamentarnej dopełnił się w pierwszej dekadzie transformacji (Smith i Timar 2010, Stenning 2004). W okresie 10 lat od upadku socjalizmu uformował się zatem nie tylko nowy system społeczno-gospodarczy (Deacon 2000, Bhalla, Lapeyre 2004), ale także rynek pracy oraz związana z nim segmentacja i nierówności (Rashid i inni 2005).

Zmienne wykorzystane w analizie odnosiły się do podziału ludności aktywnej zawodowo na główne kategorie społeczno-zawodowe ${ }^{3}$ oraz bezrobotnych. W każdym z badanych krajów taki podział wprost odzwierciedlał zróżnicowania na tle społeczno-materialnym, czytelnie wskazując ,wygranych” i ,przegranych" w procesie zmiany systemu. Przyjęta klasyfikacja ludności wprost nawiązuje do klasyfikacji wykorzystywanych w badaniach międzynarodowych (por. Duncan i Duncan 1955, Morgan 1975, Scott 1988, Musterd 2005, Butler i inni 2008).

Informacje dotyczące struktury społeczno-zawodowej ludności dostępne były w dużej dezagregacji przestrzennej. Podstawowymi jednostkami przestrzennymi, dla których zgromadzono analizowany materiał, były małe, relatywnie homogeniczne obszary o średniej liczbie mieszkańców poniżej 4000 osób $^{4}$. Tym

${ }^{3}$ Podziału ludności na kategorie społeczno-zawodowe w 3 badanych miastach dokonano zgodnie z „Międzynarodową Standardową Klasyfikacją Zawodów” (International Standard Classification of Occuaptions) (ISCO) (http://epp.eurostat.ec.europa.eu/portal/ page/portal/income_social_inclusion_living_conditions/documents/tab/Tab/ISCO\%2020 11.pdf).

${ }^{4}$ Niestety w przypadku Bukaresztu wyniki spisu powszechnego z 2002 roku dostępne były jedynie dla większych jednostek podziału administracyjnego, które, stosując nomenklaturę przyjętą w Polsce, nazwać można ,jednostkami osiedlowymi” (por. Marcińczak 2009, Węcławowicz 2003). W przypadku Bukaresztu w 2002 roku, średnia liczba mieszkańców w jednostkach tego typu wynosiła około 10000 osób. Podstawową jednostką przestrzenną dla Tallina był kwadrat (element siatki) o wymiarach 500x500 metrów. Średnia liczba ludności w takiej jednostce wynosiła około 1000 osób. Podobne 
samym jednostki te, odnosząc się do terminologii stosowanej w Polsce, zwane będą w pracy jako ,jednostki statystyczne”. Warto w tym miejscu podkreślić, że zarówno przeciętna liczba ludności w tych mikro-obszarach oraz ich cechy przestrzenne mieściły się w ogólnie przyjętej definicji ,jednostki spisowej” (census tract), standardowo stosowanej w badaniach nad segregacją w Europie i Ameryce Północnej (por. van Kempen 2007).

Ze względu na postawiony cel badawczy praca, oprócz wprowadzenia, dzieli się na siedem rozdziałów. Rozdział drugi dokonuje przeglądu koncepcji teoretycznych, dotyczących powstawania i ewolucji wzorów segregacji społecznej we współczesnym kapitalizmie, a także poddaje analizie znaczenie samego terminu „segregacja społeczna” i prezentuje zastosowane metody badawcze. Rozdział trzeci podsumowuje stan wiedzy o procesach, wymiarze i geografii segregacji społecznej w mieście epoki socjalizmu i po jej zakończeniu. Kolejna część pracy ilustruje generalny obraz rozwoju struktur społeczno-przestrzennych w Bukareszcie, Tallinnie i Warszawie, a także ich sytuację społeczno-gospodarczą na początku XXI wieku. W rozdziale piątym przedstawione zostały wyniki analizy poziomu segregacji społecznej. Rozdział szósty poświęcony został zróżnicowaniu przestrzennemu lokalnych wzorów segregacji społecznej w trzech miastach. Ostatni rozdział podsumowuje wyniki pracy i prezentuje odpowiedź na pytanie dotyczące kwestii segregacji społecznej w okresie transformacji ustrojowej, a przede wszystkim absolutnego i relatywnego, w odniesieniu do miast po obu stronach Atlantyku, wymiaru tego zjawiska w mieście postsocjalistycznym.

rozmiarowo były jednostki statystyczne, dla których agregowane były dane spisowe w Warszawie. 


\section{Rozdział 2}

\section{Segregacja spoteczna jako przedmiot badań}

\section{Podstawy teoretyczne}

Segregacja przestrzenna ludności ze względu na status społeczny, wyznanie czy pochodzenie etniczne/rasowe, towarzyszy od wieków zjawisku urbanizacji bez względu na krąg kulturowy (Nightingale 2012). Przestrzenny podział ludności według różnych cech personalnych i grupowych wydaje się być immanentną cechą zbiorowisk miejskich. Biorąc pod uwagę historię cywilizacji, badania nad zjawiskiem segregacji społecznej w przestrzeni wielkiego miasta trwają nieprzerwanie jedynie od ponad stu lat. Pierwsze prace nad zróżnicowaniem społecznym i przestrzennym ludności wybranych dzielnic wielkiego miasta, w postaci dokładnych map i ich analizy, pojawiły się w literaturze już pod koniec XIX wieku (Węcławowicz 2003). Spośród garstki opracowań, jakie wtedy powstały, chyba najlepiej znane są te autorstwa angielskiego przedsiębiorcy, filantropa i badacza społecznego - Charlesa Bootha. Jako pierwszy dokonał on szczegółowej analizy zróżnicowania przestrzennego struktury społeczno-zawodowej wybranych dzielnic Londynu (Booth 1887, 1888).

Jednakże bez porównania większe znaczenie dla rozwoju badań nad ewolucją struktury społeczno-przestrzennej ośrodków miejskich miała szkoła chicagowska socjologii miasta. Dzięki pracy badaczy skupionych w Chicago na początku XX wieku powstała pierwsza zwarta koncepcja teoretyczna, wyjaśniająca naturę i powstawanie obszarów zamieszkanych przez grupy ludności o różnym statusie społecznym oraz odmiennym pochodzeniu etnicznym i rasowym (Park, Burgess i McKenzie 1925). Główne tezy tej szkoły, a także opracowane modele struktury przestrzennej miasta, nazywane obecnie klasycznymi (koncentryczny, sektorowy i wieloośrodkowy), na stałe trafiły do podręczników z zakresu geografii urbanistycznej (Liszewski 2012) i geografii społecznej miasta (Węcławowicz 2003). Z uwagi na fakt, iż prace testujące adekwatność modeli klasycznych do opisu różnic w rozmieszczeniu grup społecznych, demograficznych i etnicznych/rasowych oraz towarzyszących im warunków mieszkaniowych w miastach, bazujące przy tym na metodzie analizy czynnikowej, także zostały szeroko omówione w literaturze przedmiotu (Węcławowicz 1988, 2003, Zborowski 2005, Marcińczak 2009), w niniejszym opracowaniu opis udziału ekologii społecznej w rozwoju badań nad segregacją ograniczony zostanie do elementów kluczowych. 
Najistotniejszym wkładem szkoły chicagowskiej w studia nad segregacją wydaje się być odkrycie regularności przestrzennej $\mathrm{w}$ działaniu procesów inwazji i sukcesji, które odpowiedzialne są za zmiany w rozmieszczeniu poszczególnych grup społecznych i etnicznych/rasowych w wielkim mieście. Fakt istnienia i ewolucji stref, sektorów i mniejszych części miasta o odmiennym standardzie i charakterze zabudowy, ale przede wszystkim o zasadniczo różnym składzie społecznym mieszkańców, stanowi fundament badań nad zjawiskiem segregacji. Równie istotnym osiągnięciem szkoły chicagowskiej jest wprowadzenie i popularyzacja indeksów segregacji. Miary te pojawiły się w literaturze przedmiotu już w późnych latach 1940. (Jahn, Schmid i Schrag 1948), ale status standardowych narzędzi badawczych zawdzięczają badaczom z Chicago (Duncan i Duncan 1955). Upowszechnienie indeksów segregacji w efekcie zoperacjonalizowało rozwój koncepcji teoretycznych w drugiej połowie XX wieku (Grannis 2002). Dzięki szkole chicagowskiej do zakresu pojęciowego badań nad segregacją na stałe wchodzi termin ,getto” (Philpott 1978).

O ile krytyka ekologii społecznej skupiała się zazwyczaj na zbyt silnym przywiązaniu jej twórców do analogii ze świata przyrody i ignorowaniu indywidualnych wyborów oraz preferencji pojedynczych mieszkańców (Walmsley i Lewis 1997), w kontekście współczesnych zmian w funkcjonowaniu kapitalizmu wskazać można jeszcze dwa elementy wymagające recenzji. Pierwszym z nich jest rozwój koncepcji teoretycznej w oparciu o miasto, które ówcześnie zajmowało unikalną pozycję w skali globalnej (Amin i Graham 1997). W początku $\mathrm{XX}$ wieku, po wielkim pożarze, który zniszczył znaczną część miasta, Chicago zostało szybko odbudowane i dzięki położeniu w pobliżu wielkich jezior i linii kolejowej, szybko stało się jednym z najważniejszych ośrodków przemysłowych Stanów Zjednoczonych. Mechanizacja uprawy bawełny na południu USA oznaczała nieprzebraną rzeszę migrantów (głównie afro-amerykanie), szukających pracy w nowopowstających fabrykach. W tym samym okresie, gwałtowny rozwój przemysłu ściągnął do miasta także tysiące emigrantów z Europy (Niemcy, Polacy, Szwedzi, Włosi, Żydzi). Szybko rosnąca liczba mieszkańców odmiennych etnicznie, rasowo i religijnie doprowadziła do powstania widocznych i bardzo silnych podziałów społeczno-przestrzennych.

W nieco szerszym ujęciu ten sam problem dotyczy bazowania na systemie społeczno-gospodarczym, w którym dominował praktycznie nieograniczony wolny rynek. Ignorując zatem wpływ państwa oraz wytworzonych przez nie instytucji, mających na celu przeciwdziałanie nierównościom społecznym, tezy szkoły chicagowskiej, a przynajmniej część wyjaśniająca powstawanie zróżnicowań, może okazać się nieadekwatna w innych miastach i krajach (Van Kempen i Özüekren 1998). Drugim elementem wymagającym odniesienia jest post- 
rzeganie miasta w oderwaniu od procesów globalizacji, które we współczesnych realiach stanowią istotne czynniki kształtujące zjawisko segregacji w mieście (Van Kempen 2007). Podobna krytyka dotyczy także koncepcji kontynuujących tradycje ekologii społecznej, a rozwiniętych w ramach analizy obszarów społecznych (Shevky i Bell 1955) oraz ekologii czynnikowej (Węcławowicz 1988).

Odpowiedzią na całkowity brak w badaniach nad procesami i wzorami segregacji społecznej odniesienia do preferencji i wyborów dokonywanych przez jednostki, było włączenie się w nie podejścia behawioralnego (Walmsley i Lewis 1997). Tym samym wzory przestrzenne segregacji zaczęto odczytywać także jako wynik indywidualnych upodobań i podejmowanych decyzji (Van Kempen i Özüekren 1998). Studia prowadzone w ramach tego podejścia koncentrowały się przede wszystkim na poziomie satysfakcji, bądź jej braku, z zajmowanego miejsca w przestrzeni rezydencjonalnej miasta (Brown i Moore 1970). Rozbieżności pomiędzy aspiracjami a standardem miejsca zamieszkania prowadzić mogą zatem do jego zmiany. W kontekście wpływu indywidualnych wyborów na poziom segregacji należy także wspomnieć prace Thomasa Schellinga (2006), który za pomocą teorii gier w sposób klarowny zademonstrował, jak decyzje mieszkaniowe pojedynczych gospodarstw domowych, a w szczególności te, nie mające na celu znacznej separacji od innych grup społecznych, prowadzić mogą do silnej segregacji w przestrzeni miasta.

Pamiętać także należy, że poziom braku satysfakcji, który przyczynia się do podjęcia decyzji o migracji mieszkaniowej, zależy od statusu społecznego i przynależności etnicznej/rasowej poszczególnych osób. Preferencje i decyzje dotyczące wyboru miejsca zamieszkania zależą także od fazy w cyklu życia rodziny (gospodarstwa domowego), wieku członków rodziny oraz jej wielkości i składu (Rossi 1955, Clark i Dieleman 1996). Powyższe różnice oraz nakładające się na nie zróżnicowanie w statusie materialnym manifestowane są poprzez wybór mieszkań o określonej powierzchni, typie, lokalizacji i cenie. Skoro zasoby mieszkaniowe o różnym standardzie i charakterze rozmieszczone są nierównomiernie w przestrzeni miasta (regionu miejskiego), to wybór pojedynczych gospodarstw domowych prowadzi do segregacji. Główna krytyka takiej konceptualizacji powstawania wzorów przestrzennych segregacji dotyczy przede wszystkim braku uwzględnienia czynników natury instytucjonalnej, takich jak utrudnienia lub ułatwienia w dostępie do zasobów mieszkaniowych (Van Kempen i Murie 2009).

Początków podejścia instytucjonalnego w studiach nad zjawiskiem segregacji społecznej doszukiwać się można w końcu lat 1960. Za umowną datę przyjmuje się rok 1967, gdy drukiem ukazała się książka J. Rexa i R. Moora Race, Community and Conflict (Van Kempen i Özüekren 1998). Centralnym punktem tej kon- 
cepcji jest przeświadczenie, że zasoby mieszkaniowe, a zwłaszcza te pożądane przez ogół społeczeństwa, są dobrem ograniczonym, a mieszkańców podzielić można na grupy/klasy (housing classes) ze względu na zróżnicowany dostęp do tych zasobów. Aktywna rola państwa w regulowaniu dostępu do zasobów mieszkaniowych ma mediujący wpływ na związek pomiędzy dochodami a warunkami mieszkaniowymi. Przyczynia się ona do segmentacji rynku mieszkaniowego, gdzie oprócz znacznego udziału własności prywatnej, istotną rolę przypisać można zasobom publicznym o różnym standardzie i odmiennych kryteriach alokacji mieszkańców. Między innymi to właśnie zakres zaangażowania państwa w dystrybucję zasobów mieszkaniowych stanowi jeden z kluczowych elementów, który w różnym stopniu kształtuje zjawisko segregacji w miastach Stanów Zjednoczonych i w miastach europejskich (Van Kemepen i Murie 2009).

W latach 1970. i 1980. uwaga podejścia instytucjonalnego skupiona została na praktykach poszczególnych aktorów działających na szeroko pojętym rynku mieszkaniowym, a w szczególności na ich celach oraz systemie wartości, które mogły faworyzować jedne grupy społeczne kosztem innych (Pahl 1975). Nurt ten rozwinięty został także $\mathrm{w}$ ramach szerszego podejścia, jakim jest geografia dobrobytu (Kaczmarek 2004). Szczególnego znaczenia nabrała w tym kontekście praca D. Harveya Social Justice and the City z 1973 roku, w której autor zaproponował rozpatrywanie nierówności społecznych i segregacji w kontekście funkcjonowania systemu kapitalistycznego. Na podkreślenie zasługuje przede wszystkim naświetlenie roli rozwiązań instytucjonalnych, planów zagospodarowania przestrzennego czy mechanizmów przyznawania kredytów hipotecznych, w produkcji i reprodukcji zróżnicowań przestrzennych na tle statusu (klasy) społecznego i przynależności rasowej.

Gwałtowny rozwój podejścia instytucjonalnego w studiach nad nierównościami społecznymi i segregacją przypada na lata 1990. i trwa do dzisiaj. Wzrost zainteresowania rolą szeroko rozumianych instytucji (zarówno tych formalnych, jak i nieformalnych, jak kultura i zwyczaje) w geografii miasta, powiązać można z szerszym trendem w naukach społecznych, do powstania którego przyczyniły się przede wszystkim prace D. Northa (1990) oraz G. Esping-Andersena (1990). Pierwszy z badaczy zwrócił uwagę, że zarówno możliwość zmiany utartego schematu działania, a w rezultacie większa efektywność i rozwój gospodarczy, jak również utknięcie na ścieżce rozwoju nie gwarantującej oczekiwanych zmian, zależą od lokalnego kontekstu instytucjonalnego, który odzwierciedla długotrwale formowany profil społeczno-gospodarczy państwa czy regionu. Wyniki studiów G. Esping-Andersena (1990) wskazały na czytelne różnice pomiędzy krajami Europy Zachodniej i Stanami Zjednoczonymi w charakterze i skali redystrybucji dochodów oraz rozmiarze świadczeń i osłon socjalnych 
w ramach państwa dobrobytu, które bezpośrednio kształtują poziom rozwarstwienia społecznego.

W badaniach nad zjawiskami nierówności społecznych i segregacji wpływ szeroko rozumianego podejścia instytucjonalnego zbiegł się w czasie z ożywioną debatą dotyczącą wzrostu podziałów społecznych w miastach, w rezultacie zmian wywołanych funkcjonowaniem globalnego i neoliberalnego kapitalizmu oraz transformacją w gospodarce wchodzącej w fazę postindustrialną.

Obecnie przyjmuje się, że skala i intensywność nierówności społecznych oraz ich materialny zapis w przestrzeni miasta, jakim jest segregacja społeczna, zależą od profilu funkcjonalnego, historii, kontekstu instytucjonalnego oraz położenia ośrodka w hierarchii osadniczej (Glaeser 2011, Van Kemepen i Murie 2009). Innymi słowy kontekst lokalny (genius loci), będący odzwierciedleniem interakcji zachodzących pomiędzy przestrzenią i społeczeństwem w bliższej i dalszej przeszłości, warunkuje możliwości rozwoju gospodarczego i społecznego w chwili obecnej. Ścieżka rozwoju miasta zatem współdeterminuje wpływ procesów, takich jak globalizacja, umiędzynarodowienie handlu i produkcji oraz restrukturyzacja gospodarki, na charakter zmian lokalnych. Unifikujące działanie procesu globalizacji nie wszędzie oznacza identyczne rezultaty, a jego ostateczny efekt w wybranej lokalizacji zależy od zastanej tam struktury społecznoekonomicznej i obecności oraz zakresu państwa dobrobytu (państwa opiekuńczego) (Marcińczak i inni 2012).

Globalizacja oraz związany z nią nowy, międzynarodowy podział pracy zmieniły relacje gospodarcze na całym świecie. Wielkie miasta, centra przemysłowe Europy Zachodniej oraz Ameryki Północnej, odczuły zasadnicze zmiany, gdy część produkcji, przede wszystkim działy tradycyjne wymagające dużych nakładów słabo lub średnio wykwalifikowanej siły roboczej, zostały stopniowo przeniesione najpierw na przedmieścia, a następnie do krajów rozwijających się (Scott i Storper 1986). W krajach wysoko rozwiniętych pozostały zwłaszcza dziedziny przemysłu oparte na wysokiej technologii, wykwalifikowanej sile roboczej oraz sektorze usług wyższego rzędu. Związany z nimi rozwój funkcji metropolitalnych (por. Maik 2003) przyczynił się z kolei do powstawania nowych lokalnych i regionalnych klastrów przemysłu kreatywnego oraz centrów usług finansowych o międzynarodowym zasięgu oddziaływania (Musterd i Murie 2010). Zmiany wywołane przez proces globalizacji stworzyły zatem nowe warunki dla przebiegu zjawiska segregacji społecznej.

Opinie dotyczące natury podziałów społecznych wyłaniających się z nowego, globalnego kapitalizmu nie są jednomyślne. Zdaniem S. Sassen (1991), nierówności wynikające $\mathrm{z}$ nowego podziału pracy i przemian w gospodarce fazy postindustrialnej mają kluczowe znaczenie dla przebiegu procesów społecznych 
w miastach, które autorka nazywa globalnymi. W ośrodkach należących do tego wąskiego grona (ikonami są Nowy Jork, Londyn i Tokio) dochodzi do swoistej segmentacji rynku pracy. Wielkie, szybko rozwijające się gospodarczo miasta o liberalnym charakterze, stają się miejscem docelowym migracji pracowników zaliczanych do nowej elity, zwanej klasą kreatywną (Florida 2003). Gwałtowny rozwój gospodarki opartej na wiedzy oznacza równie gwałtowny wzrost liczby wysoko wykwalifikowanych pracowników o ponadprzeciętnych dochodach. Miasta globalne stanowią także docelową destynację rzeszy migrantów o niskich lub bardzo niskich kwalifikacjach, którzy znajdują pracę w nisko płatnych usługach, na stanowiskach, które zazwyczaj nie gwarantują jakiegokolwiek awansu i kariery (Glaeser 2011). Tym samym szybko rozrasta się także dół hierarchii dochodów. Upadek tradycyjnego przemysłu wytwórczego oznacza szybki ubytek miejsc pracy dla szeroko rozumianej klasy średniej. Taki charakter zmian na rynku pracy prowadzi niechybnie do polaryzacji społecznej, gdzie główna linia podziału oddziela pracujących bogatych od pracujących biednych (Sassen 1991). Efekt wywołany przez proces polaryzacji społecznej w miastach globalnych nazywany także bywa „nowym miejskim dualizmem”, a sam typ ośrodka zwany jest „miastem dualnym” (Castells 1989). O ile praca S. Sassen (1991) jest bardzo oszczędna w kwestii przestrzennej formy polaryzacji społecznej, koncepcja „miasta dualnego" M. Castellsa (1989) zakłada proporcjonalny wzrost poziomu segregacji społecznej lub też istnienie miasta „podwójnie dualnego” (Lisowski 2000, s. 239).

Jednak nie każde wielkie miasto osiągnęło status i rangę Nowego Jorku czy Londynu. Według W. J. Wilsona (1987), polaryzacja społeczna nie zawsze musi powielać schemat naszkicowany przez koncepcję miasta globalnego. W miastach, w których nie udało się zrestrukturyzować gospodarki tak, aby odpowiadała wymogom globalnego kapitalizmu, pojawia się niedopasowanie pomiędzy kwalifikacjami mieszkańców a nowymi miejscami pracy. Tym samym linia podziałów społecznych oddziela tych mających pracę od bezrobotnych. Należy także podkreślić przestrzenny aspekt koncepcji W. J. Wilsona (1987). Otóż wyniki badań z wielkiego miasta przemysłowego Stanów Zjednoczonych z początków epoki Ronalda Reagana wskazywały na strefę wewnętrzną, jako główny obszar koncentracji ludności ubogiej i wykluczonych społecznie. Przyczynił się do tego exodus przemysłu na przedmieścia, a wraz z nim miejsc pracy dla ludności o niższych kwalifikacjach oraz profesjonalizacja rynku pracy w centrum.

Dwie powyższe propozycje teoretyczne, naświetlające charakter nierówności społecznych we współczesnych miastach krajów wysoko rozwiniętych, stanowić mogą podstawę dla podziału miast ze względu na naturę procesów społecznych. Jeśli ewolucja struktury społeczno-zawodowej ludności wskazuje na trend typo- 
wy dla miasta globalnego, należy się spodziewać polaryzacji społecznej w kształcie naszkicowanym przez S. Sassen (1991). Jeżeli natomiast ścieżka rozwoju miasta wskazuje na tradycyjny region przemysłowy w stadium deindustrializacji, wtedy zmiany w strukturze społecznej przypominać mogą model W. J. Wilsona (1987). Zdaniem niektórych badaczy, taki model nierówności społecznych cechować może także szerszą grupę miast, które ze względu na położenie czy rangę w hierarchii osadniczej, nie zdołały się na dobre zakotwiczyć w globalnym przepływie pracy i kapitału (Burgers i Musterd 2002).

Wymowa powyższych koncepcji wskazuje na niebagatelne znaczenie kontekstu lokalnego w kształtowaniu wzorów nierówności społecznej i segregacji. W tym miejscu raz jeszcze podkreślić należy, że kontekst lokalny rozumiany jest jako efekt działania różnych reżimów w ramach szeroko pojętego państwa dobrobytu oraz społecznej, gospodarczej i przestrzennej ścieżki rozwoju miasta lub regionu (Marcińczak i inni 2012).

W zasadzie zaraz po pojawieniu się $\mathrm{w}$ literaturze przedmiotu modeli polaryzacji społecznej $\mathrm{w}$ mieście dualnym/globalnym, zostały one poddane w wątpliwość. Uwagę zwracano na zbyt daleko posunięte uproszczenia odnośnie zachodzących zmian (Marcuse 1989). Badania testujące hipotezę miasta globalnego, potwierdzając wzrost nierówności społecznych, wskazywały raczej na profesjonalizację struktury społeczno-zawodowej niż na polaryzację: absolutnemu i relatywnemu wzrostowi podlegała głównie góra hierarchii społecznej (Hamnett 1996, Butler i inni 2008). Gwałtowny wzrost podziałów społecznych jest jednak faktem, ale zarówno w aspekcie społeczno-materialnym, jak i przestrzennym, naturę nowych nierówności lepiej oddaje termin „fragmentacja”, który zakłada rozpad społeczeństwa nie na dwie/trzy główne kategorie, lecz na wiele słabo połączonych ze sobą elementów (Musterd i Ostendorf 2012a).

Sygnałów, że silna polaryzacja/dualizacja społeczna i bliżej niesprecyzowane, wynikające z niej wzory segregacji, występować mogą jedynie w warunkach niczym nieograniczonego wolnego rynku, doszukać się można już w pracy autorów terminu ,miasto dualne”. Jednakże wyraźne wskazanie roli państwa dobrobytu w kształtowaniu form nierówności społecznej oraz segregacji należy do badaczy europejskich (Van Kemepen i Murie 2009).

Koncepcja „państwa dobrobytu” jest dosyć pojemna i obejmuje takie dziedziny działalności państwa, jak redystrybucja dochodów i związany z nią system podatkowy, system ubezpieczeń zdrowotnych, system rent i emerytur, różnego rodzaju osłony socjalne i ich zakres, ale także politykę mieszkaniową prowadzoną w danym kraju/regionie (Palier 2010). Stopień i charakter zaangażowania państwa w powyższe działy polityki społecznej i gospodarczej jest różny w różnych krajach. Największy wpływ na badania nad segregacją i nierównościami 
społecznymi wywarła praca G. Esping-Andersena (1990), która przedstawia spójną typologię odmiennych wersji państwa dobrobytu. Wyróżnione zostały trzy podstawowe modele:

1) liberalny (liberal) - w którym rola państwa ograniczona jest do minimum zapewniającego sprawne funkcjonowanie gospodarki (Stany Zjednoczone, Australia);

2) korporacyjny (corporatist) - rola państwa jest bardziej istotna niż w modelu liberalnym, jednak ograniczona w kontekście redystrybucji dochodów. Reżim ma na celu podtrzymanie różnic w statusie społecznym oraz tradycyjnych instytucji, jak kościół czy rodzina (Austria, Francja, Niemcy);

3) socjaldemokratyczny (social democratic) - redystrybucja dochodów ma na celu jak największe zniwelowanie różnic - promocja równości szans wszystkich obywateli, bardzo silny i rozległy system osłon socjalnych (państwa skandynawskie) (ibid.).

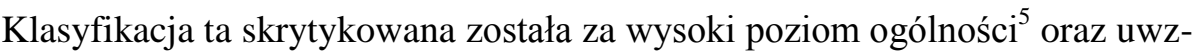
ględnienie zbyt małej liczby elementów, wchodzących w zakres państwa dobrobytu - nie wzięto pod uwagę $\mathrm{m}$. in. polityki mieszkaniowej (Murie 1998). Zdaniem J. Allen i innych (2008), do wymienionych trzech idealnych modeli dodać należy także typ południowo-europejski (Grecja, Portugalia oraz do pewnego stopnia Włochy i Hiszpania), który umiejscowić można pomiędzy modelem korporacyjnym a liberalnym.

Podobną typologię, już z uwzględnieniem modelu południowo-europejskiego, odnaleźć można także w odniesieniu do składowej „państwa dobrobytu”, jaką jest system mieszkaniowy, jeden z brakujących elementów w typologii G. Esping-Andersena (1990). W odniesieniu do kwestii mieszkaniowej wyróżnić zatem można (Arbaci 2007, s. 412):

1) model liberalny, zakładający dominację własności prywatnej, różne formy pomocy państwa w zakupie mieszkań, bardzo ograniczoną rolę zasobów publicznych, które często są segregowane w przestrzeni i przeznaczone dla osób najbiedniejszych;

\footnotetext{
${ }^{5}$ Zmiany wywołane w Europie po 1990 roku, które zapoczątkowały okres transformacji ustrojowej w byłych krajach socjalistycznych, wskazują na wyłonienie się kolejnej 'mutacji', zwanej modelem postsocjalistycznym (Aidukaite 2009, 2011). Charakter i różnice w przemianach dawnego, „totalitarnego” państwa dobrobytu w krajach byłego Bloku Wschodniego omówione zostaną w części poświęconej nierównościom i segregacji w mieście postsocjalistycznym.
} 
2) model południowo-europejski, gdzie rola państwa jest niemal równie ograniczona, a głównym aspektem odróżniającym ten typ od modelu liberalnego jest rozwój nieformalnego rynku mieszkaniowego (budowa bez jakichkolwiek pozwoleń przez osoby prywatne);

3) model korporacyjny, gdzie rynek prywatnych i publicznych mieszkań na wynajem jest zintegrowany w jeden system. Struktura rynku mieszkaniowego w odniesieniu do form własności (publiczna, prywatna i spółdzielcza) jest wyrównana;

4) model socjaldemokratyczny, gdzie podobnie do modelu korporacyjnego system mieszkaniowy jest zintegrowany, a struktura własności zasobów mieszkaniowych jest wyrównana. Typ ten z kolei wyróżnia się w tym, że państwo promuje mieszkania na dhugotrwały wynajem w sektorze publicznym i spółdzielczym. Sektor publiczny konkuruje z sektorem prywatnym na rynku mieszkań na wynajem. W odróżnieniu od modeli liberalnego i południowo-europejskiego, zasoby komunalne nie są separowane w przestrzeni i nie towarzyszy im stygmatyzacja.

Różne modele państwa dobrobytu stwarzają zatem odmienne warunki dla rozwoju i rozmiaru nierówności społecznych. W przypadku reżimów socjaldemokratycznego i korporacyjnego, które oznaczają istotny udział zatrudnienia w sektorze publicznym oraz rozbudowany system ochrony pracowników i zasiłków dla bezrobotnych, negatywne skutki restrukturyzacji gospodarki oraz związane z nią procesy społeczne mogą zostać złagodzone (Musterd i Ostendorf 1998). Znajduje to potwierdzenie w generalnie niższym poziomie nierówności społecznych w krajach Europy Północnej, Zachodniej i Południowej niż w znanych z modelu liberalnego i dominacji wolnego rynku Stanach Zjednoczonych (Marcuse i Van Kempen 2009).

Zmiany w obrębie regulacji związanych z państwem dobrobytu mogą oznaczać przekształcenia w charakterze redystrybucji dochodów, a w rezultacie obniżenie dochodów grup, polegających na różnego rodzaju zasiłkach i innych formach pomocy społecznej. Jednak to system mieszkaniowy odpowiada za dostęp poszczególnych grup społecznych do zróżnicowanych zasobów mieszkaniowych, a także wpływa na ich formę i lokalizację w przestrzeni miasta (Musterd i Ostendorf 2012a, Murie 2009). Prawidłowości zaobserwowane w przypadku różnych poziomów nierówności społecznych po obu stronach Atlantyku sprawdzają się także w przypadku poziomów segregacji. Wielkie miasta Stanów Zjednoczonych odznaczają się silniejszą segregacją etniczną/rasową i społeczną niż miasta europejskie (Musterd 2005, Musterd i Van Kempen 2009).

Negatywne efekty społeczne wynikające ze zmian zapoczątkowanych w globalnym kapitalizmie ponad trzy dekady temu nie ominęly starego kontynentu. 
W Europie polaryzujące efekty restrukturyzacji gospodarczej i globalnego podziału pracy zbiegły się z postępującym urynkowieniem ideałów państwa dobrobytu, redukcją osłon socjalnych, promocją własności prywatnej w odniesieniu do zasobów mieszkaniowych, a także obniżaniem statusu społecznego osiedli komunalnych (Musterd i Ostendorf 1998). Obraz nowego państwa opiekuńczego, który wyłania się z tych przemian, mieści w sobie coraz mniej sektora publicznego. Nowa forma oznacza silniejszą stratyfikację społeczną oraz bardziej czytelny związek pomiędzy pozycją społeczną i dochodem a formą własności i miejscem zamieszkania (Van Kemepen i Murie 2009). Innymi słowy, nawet jeśli od końca lat 1970. na kontynencie europejskim mamy raczej do czynienia z profesjonalizacją społeczeństwa, niż jego polaryzacją (Hamnett 1994), poziom nierówności społecznych i segregacji wykazywał trend zwyżkowy.

Przegląd koncepcji teoretycznych dotyczących nierówności społecznych i segregacji społecznej odsłania szereg czynników, determinujących skalę i rozwój tych zjawisk, a także wskazuje na związki pomiędzy profilem miasta a formą przemian społecznych. Odwołując się zatem do argumentów głoszących zalety metodologii środka, czyli eklektycznego podejścia teoretycznego, które łączy na zasadzie krytycznej oceny różne koncepcje wyjaśniające to samo zjawisko (Maik 1998, 2007), z pewną dozą ogólności przyjąć można, że wzory zróżnicowań społecznych i ich manifestacja w przestrzeni miasta zależy od motywów i decyzji pojedynczych ludzi, które podejmowane są w określonym kontekście historycznym, społecznym, gospodarczym i przestrzennym. W obecnej fazie rozwoju społeczno-gospodarczego krajów wysokorozwiniętych, do grona których kraje postsocjalistyczne dołączyły w ostatniej dekadzie XX wieku, wzrost nierówności społecznych i segregacji wydaje się być nieuniknionym kosztem społecznym globalizacji pracy i kapitału oraz bolesnego przejścia od etapu industrialnego do stadium postindustrialnego. W miastach, w których proces ten przebiegał sprawnie i zaowocował rozwojem przemysłu kreatywnego oraz sektora finansowo-bankowego, spodziewać się można silniejszych nierówności społecznych i wyższego poziomu segregacji. Obszary, którym z uwagi na brak dostosowania odziedziczonej z epoki industrialnej struktury przestrzennej i funkcjonalnej nie udało się dopasować do nowych trendów, w teorii powinny odznaczać się słabszym rozwarstwieniem społecznym i segregacją. Dalsza część pracy pozwoli odpowiedzieć na pytanie, jak głoszone w literaturze zależności pomiędzy charakterem miasta i formą nierówności społecznych przystają do obrazu zmian zachodzących na naszych oczach w miastach europejskich, położonych na wschód od dawnej żelaznej kurtyny. 


\section{Znaczenie i pomiar}

Segregacja jest zjawiskiem, które dotyczy każdej domeny życia codziennego: miejsc zamieszkania, pracy czy też korzystania $z$ rozrywki i innych usług (Schnell i Yoav 2001). Jednakże z uwagi na dostępność danych, badania nad podziałami społecznymi najczęściej ograniczone są do przestrzeni mieszkaniowych. W związku z trwaniem ożywionej dyskusji dotyczącej wzrostu nierówności społecznych w ostatnich trzech dekadach, termin „segregacja” powtarzany był niemal jak mantra. Niestety, pomimo wciąż rosnącej liczby prac drążących temat segregacji społecznej i etnicznej, zjawisko to często było definiowane w różny sposób. Pamiętając o tym, że pomiar operacjonalizuje zjawisko segregacji, a w literaturze funkcjonuje około 30 mierników segregacji będących funkcją od dwóch do jedenastu zmiennych (Grannis 2002), można stwierdzić, że dalszych komplikacji nastręcza fakt stosowania odmiennych metod badawczych, towarzyszących różnemu pojmowaniu segregacji. W skrajnych przypadkach oznaczać to może sprzeczne rezultaty badań nad tą samą populacją. Konflikt ten bardzo dobrze oddaje debata nad zjawiskiem segregacji w Bradford (Wielka Brytania) pomiędzy L. Simpsonem (2004) oraz R. J. Johnstonem i innymi (2005).

Przytoczona już w tej pracy definicja słownikowa terminu „segregacja” okazuje się zbyt ogólna w porównaniu z tym, jak zjawisko to rozumiane jest obecnie w literaturze przedmiotu. W związku $\mathrm{z}$ tym, w celu uniknięcia zamieszania terminologicznego, fundamentalnym wydaje się być podkreślenie przestrzennego aspektu segregacji. Innymi słowy, termin ten odnosi się do podzialu na kategorie spoleczne (etniczne, rasowe, religijne, etc.), który manifestowany jest $\boldsymbol{w}$ przestrzeni oraz mierzony na podstawie danych agregowanych dla zazwyczaj niewielkich jednostek podziału administracyjnego lub statystycznego miasta, czy regionu. Tym samym zjawisko segregacji, a przede wszystkim metody jego pomiaru i związana $\mathrm{z}$ nimi konceptualizacja problemu, wprost wpisują się w obecnie szeroki zakres przedmiotowy dyscypliny, jaką jest geografia miasta (Maik 2012). Ta immanentna cecha segregacji odróżnia ją zatem od terminów pokrewnych, takich jak: nierówności społeczne, czy segmentacja społecznomieszkaniowa (Murdie i Borgegård 1998), które nie oznaczają konkretnych efektów przestrzennych. W celu operacjonalizacji badań zjawisko segregacji rozumiane jest jako:

- wzory przestrzenne (skala, poziom i geografia podzialów spolecznoprzestrzennych)

- proces (ogól czynników natury personalnej, grupowej, i instytucjonalnej), który ksztaltuje wzory przestrzenne (Reardon 2006, Johnston i inni 2009). 
Przed przystąpieniem do przeglądu koncepcji na temat istoty i pomiaru wzorów segregacji, jeszcze jeden kluczowy element wymaga naświetlenia. Jeżeli w przypadku analizy wzorów segregacji etnicznej/rasowej powszechnie stosowane są takie pojęcia, jak mniejszość, społeczność gospodarzy, getto i asymilacja (Węcławowicz 2003, s. 79), nie znajdują one zastosowania (z wyjątkiem terminu ,getto") do opisu wzorów segregacji społecznej (podziału ludności na kategorie społeczno-ekonomiczne). W konceptualizacji rozwoju segregacji etnicznej/rasowej stosuje się także odmienne propozycje teoretyczne, które mają wyjaśniać zróżnicowania przestrzenne (Van Kempen i Özüekren 1998, Boal 1999, Musterd i Ostendorf 2012b). Jednak bez względu na aspekt podziałów społecznych (pozycja społeczna, pochodzenie etniczne/rasowe), znaczenie terminu i paleta stosowanych metod badawczych pozostają takie same.

Rozwój badań nad wzorami segregacji rasowej i społecznej, a przede wszystkim wzrastająca liczba nowych indeksów, mierzących różne aspekty przestrzennych podziałów społecznych, przyczyniły się do pojmowania segregacji jako zjawiska wielowymiarowego. Pierwsi na ten fakt zwrócili uwagę D. S. Massey i N. A. Denton (1988). Stosując zestaw kilkudziesięciu indeksów segregacji do pomiaru skali i poziomu przestrzennych podziałów rasowych w obszarach metropolitalnych Stanów Zjednoczonych, autorzy ci zaproponowali pięć podstawowych wymiarów segregacji (Massey i Denton 1988):

1) nierównomierność (unevenness) - odnosi się do stopnia nierównomierności w rozmieszczeniu danej grupy społecznej w porównaniu od innej grupy lub reszty populacji;

2) otwartość/izolacja (exposure/isolation) - określa prawdopodobieństwo spotkania się w tym samym sąsiedztwie (jednostce przestrzennej) przedstawicieli dwóch różnych grup społecznych/etnicznych (otwartość) lub członków tej samej grupy (izolacja);

3) koncentracja (concentration) - oddaje skalę obecności danej kategorii ludności w mieście w odniesieniu do innej grupy społecznej lub etnicznej, a mierzona jest jako stosunek proporcji powierzchni zajmowanych przez te grupy w mieście/regionie;

4) centralizacja (centralization) - opisuje stopień koncentracji przestrzennej danej grupy mieszkańców miasta w centrum oraz jego pobliżu (strefie wewnętrznej);

5) skupienie (clustering) - określa stopień skupienia w przestrzeni (dodatniej korelacji przestrzennej) jednostek przestrzennych zamieszkanych przez określoną kategorię ludności.

Każdemu z wyznaczonych wymiarów towarzyszy zestaw mierzących je wskaźników (Węcławowicz 2003). W ostatnich latach powyższa konceptuali- 
zacja wzorów segregacji została jednak zakwestionowana. Podział na pięć wymiarów segregacji, który zaproponowali D. S. Massey i N. A. Denton (1988), poddany został ostrej krytyce zarówno na gruncie empirycznym, jak i teoretycznym. Analizy oryginalnych danych, wykorzystanych w badaniu z 1988 roku oraz informacji pochodzących z nowszych spisów powszechnych, wskazały na istnienie jedynie dwóch wyraźnych wymiarów segregacji w obszarach metropolitalnych Stanów Zjednoczonych (Johnston i inni 2007a). Do podobnych wniosków, ale na podstawie analizy hipotetycznych przykładów wzorów segregacji (rys. 1), doszli Reardon i O'Sullivan (2004).

Obecnie przyjmuje się zatem, że na wzory przestrzenne segregacji skladaja się dwa zasadnicze wymiary (Brown i Chung 2006):

- separacja - odnosi się do nierównomierności w rozmieszczeniu ludności, której przeciwieństwem jest skupienie przestrzenne;

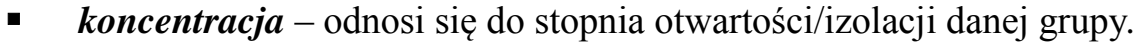

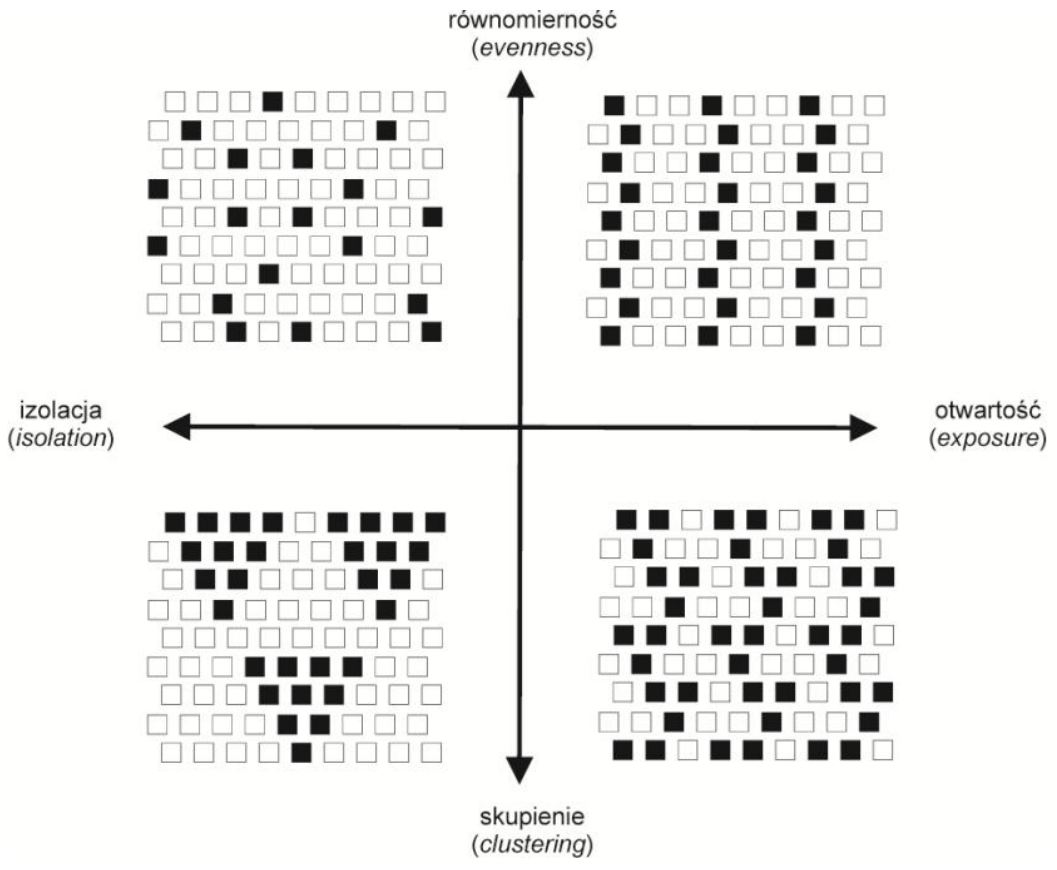

Rysunek 1: Podstawowe wymiary wzorów przestrzennych segregacji Źródło: Opracowanie własne na podstawie: Reardon i O'Sullivan (2004) 
Pierwszy z wymienionych powyżej terminów określa zatem stopień separacji grupy społecznej lub etnicznej $\mathrm{w}$ ramach większej populacji (miasto, region) i określany bywa stopniem nierównomierności w rozmieszczeniu danej grupy. Drugi termin odnosi się do koncentracji danej grupy społecznej lub etnicznej w określonych jednostkach przestrzennych (sąsiedztwach) (van Kempen i Özüekren 1998). Podobnie zjawisko definiuje S. F. Reardon (2006), który zamiast określenia „separacja” proponuje użycie terminu „segregacja”. Biorąc zatem pod uwagę, że znaczenie tych dwóch pojęć nie wykazuje większych różnic, w dalszej części rozprawy termin „separacja” stosowany będzie w odniesieniu do poziomu segregacji w skali całego miasta. W przypadku analizy zjawiska w skali lokalnej, używany będzie termin „koncentracja”.

Podział na dwa wymiary we wzorach przestrzennych segregacji odzierciedlany jest także $\mathrm{w}$ dwóch głównych podejściach badawczych $\mathrm{w}$ analizie podziałów społeczno-przestrzennych. Pierwsze z podejść bazuje na indeksach segregacji i sięga tradycjami do początków szkoły chicagowskiej (Peach 2009). Szczególną cechą indeksów segregacji, których wyniki odczytywać można jako swoiste statystyki opisowe wzorów segregacji, jest ich globalny charakter odnoszą się one do poziomu segregacji w skali miasta lub regionu.

W tym miejscu podkreślić należy bardzo istotną kwestię, jaką jest stale rosnąca liczba globalnych wskaźników segregacji. Ponad dziesięć lat temu R. Grannis (2002) stwierdził, że w studiach nad segregacją stosowano ponad 30 różnych, mniej lub bardziej złożonych mierników. Od tego czasu w literaturze przedmiotu pojawiło się kilka nowych mutacji, jak choćby indeksy zwane „przestrzennymi” (Wong 2009), które biorą pod uwagę stopień interakcji przestrzennej pomiędzy sąsiedztwami. Jednak miary te albo nie spełniły pokładanych w nich nadziei, jak w przypadku indeksów przestrzennych, które nie okazały się wystarczająco wrażliwe na geografię podziałów społecznych (Brown i Chung 2006), albo, jak wiele innych miar, nigdy nie zostały użyte na szerszą skalę w studiach porównawczych. Stąd też poniżej przedstawione zostaną te indeksy oraz inne metody stosowane $\mathrm{w}$ analizie wzorów separacji i koncentracji, które wykorzystywane są standardowo w badaniach nad wzorami segregacji oraz pozwalają na merytoryczne porównania w czasie i przestrzeni.

Z uwagi na kolosalny wpływ pracy O. D. Duncana i B. Duncan (1955) na dalszy rozwój badań, najczęściej stosownym indeksem globalnym stał się indeks braku podobieństwa (index of dissimilarity - ID) (1) oraz jego wariant, jakim jest indeks segregacji (index of segregation $-I S$ ).

Oba indeksy mierzą stopień (nie)równomierności w rozmieszczeniu poszczególnych grup społecznych lub etnicznych i przyjmują wartości od 0 do 1 (lub od 0 do 100 po prostym przekształceniu). Zasadnicza różnica pomiędzy indek- 
sem braku podobieństwa a indeksem segregacji polega na tym, że pierwsza z miar określa stopień separacji przestrzennej pomiędzy dwoma grupami społecznymi lub etnicznymi (biali i czarni, biali i Latynosi, itp.), podczas gdy druga mierzy poziom separacji przestrzennej pomiędzy daną grupą a resztą ludności (biali i pozostałe grupy etniczne/rasowe). Wartości poniżej 0.30 wskazują na niski poziom separacji lub dużą równomierność w rozmieszczeniu danej kategorii ludności. Wartości powyżej 0.60 oznaczają natomiast silną separację przestrzenną (Massey i Denton 1993).

$$
I D=\frac{1}{2} \sum_{n}\left|\left(\frac{x i}{X}\right)-\left(\frac{y i}{Y}\right)\right|
$$

$$
\begin{aligned}
& \text { gdzie: } \\
& x i \text { - liczba ludności w grupie } x \mathrm{w} \text { jednostce przestrzennej } i \text {; } \\
& y i \text { - liczba ludności w grupie } y \text { w jednostce przestrzennej } i \text {; } \\
& X \text { - ogólna liczba ludności w grupie } x \text { w mieście; } \\
& Y \text { - ogólna liczba ludności w grupie } y \text { w mieście }
\end{aligned}
$$

Jedyna różnica pomiędzy tymi miarami polega na tym, że indeks segregacji porównuje daną kategorię ludności do pozostałego ogółu populacji. Wskaźniki te w zasadzie zdominowały dziedzinę na prawie pół wieku, a okres ich „dominacji" określany bywa ironicznie jako Pax Duncana.

Już w latach 1950. pojawiły się indeksy opisujące poziom otwartości (exposure index) oraz izolacji (isolation index - II) poszczególnych kategorii społecznych lub etnicznych w mieście (Bell 1954), jednakże wskutek dominacji indeksu braku podobieństwa uległy one zapomnieniu aż do lat 1980. Badaczom segregacji przypomniał o nich S. Liberson (1980). Obydwa indeksy przyjmują wartości od 0 do 100, a ich interpretacja jest tak sama, jak w przypadku indeksu segregacji. Indeks otwartości wyraża prawdopodobieństwo interakcji pomiędzy członkami dwóch różnych grup społecznych lub etnicznych w mieście. Indeks izolacji oznacza natomiast prawdopodobieństwo interakcji pomiędzy członkami tej samej grupy. Zatem, im większa wartość tego miernika, tym dana grupa społeczna lub etniczna jest bardziej izolowana w swoich sąsiedztwach - ma mniejszą szansę na wejście $\mathrm{w}$ interakcje $\mathrm{z}$ przedstawicielami innych grup społecznych lub etnicznych. W badaniach nad segregacją społeczną najczęściej stosowany 
jest indeks izolacji (Marcińczak i inni 2012) (2) lub jego zmodyfikowana wersja $(M I I)$, która bierze pod uwagę relatywny udział danej grupy społecznej w mieście (Sin 2003) (3).

$$
I I=\sum_{n}\left(\frac{x i}{X} * \frac{x i}{t i}\right)
$$

gdzie:

$x i$ - liczba ludności w grupie $x \mathrm{w}$ jednostce przestrzennej $i$;

$t i$ - ogólna liczba ludności w jednostce przestrzennej $i$;

$X$ - ogólna liczba ludności w grupie $x$ w mieście;

$$
M I I=\sum_{n}\left(\left(\frac{x i}{X} * \frac{x i}{t i}\right)-\frac{X}{T}\right)
$$

gdzie:

$x i$ - liczba ludności w grupie $x \mathrm{w}$ jednostce przestrzennej $i$;

$t i$ - ogólna liczba ludności w jednostce przestrzennej $i$;

$X$ - ogólna liczba ludności w grupie $x$ w mieście;

$T$ - ogólna liczba ludności w mieście;

Od lat 1980. (Johnston i Jones 2010) indeksy te na stałe weszły do arsenału metod analizy przestrzennej wzorów segregacji, jako standardowe wskaźniki globalne wymiaru koncentracji (Johnston i inni 2005). Chociaż globalne indeksy segregacji skrytykowane zostały za zbyt dużą ogólność dostarczanej informacji oraz brak czułości na odmienne konfiguracje przestrzenne (Johnston i inni 2011), miary te mają nadal wiele do zaoferowania badaczom zjawiska (Simpson 2007). Standardowe mierniki globalne nie tylko są dobrze znane w literaturze przedmiotu, a ich interpretacja nie nastręcza trudności, ale przede wszystkim w sposób syntetyczny opisują silę i poziom segregacji na danym obszarze (Peach 2009). 
Drugie z podejść badawczych, szerzej rozwinięte w ostatniej dekadzie, skupia się na kwestii otwartości/izolacji poszczególnych grup społecznych, a zwłaszcza na aspekcie lokalnych wzorów koncentracji przestrzennej (Johnston i inni 2010). W ramach tej orientacji badawczej do opisu wzorów koncentracji etnicznej lub społecznej w skali całego miasta zaproponowano prostą metodę graficzną zwaną krzywą/profilem koncentracji (concentration profile), która stanowi rozwinięcie indeksu izolacji (Poulsen i inni 2002). Istotą tej metody jest ustalenie, do jakiego stopnia dana grupa społeczna lub etniczna jest skoncentrowana lub dominuje na wybranych obszarach. Zasadniczo przebieg krzywej wskazuje udział procentowy ogółu populacji w sąsiedztwach, w których dana

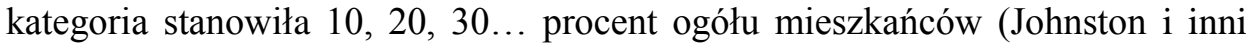
2002). Należy przypomnieć, że za wartość progową lokalnej koncentracji przestrzennej danej grupy społecznej przyjmuje się udział wynoszący ponad $30 \%$ ogółu ludności danej jednostki przestrzennej (Philpott 1978).

Najnowszym etapem w rozwoju tej prostej metody, ale jak do tej pory ograniczonym w wykorzystaniu jedynie do badania zróżnicowań etnicznych/rasowych w społeczeństwach wielokulturowych, są różne typologie, oddające stopień wymieszania etnicznego/rasowego w mieście lub regionie miejskim (Johnston i inni 2007b, Bråma 2008, Halloway i inni 2012). Zastosowanie znajdują w nich takie terminy, jak: sąsiedztwa gospodarzy (w przypadku zróżnicowań rasowych zwane „białymi”), enklawa etniczna, getto, czy sąsiedztwa wymieszane etnicznie.

Oprócz dalszego rozwoju metod analitycznych w badaniach wzorów koncentracji w skali miasta, wykraczających poza jednoliczbowe indeksy segregacji, istotnej wagi nabrała orientacja rozwinięta przez R. J. Johnstona wraz z zaspołem, która wskazała na kluczowe znaczenie badań w skali lokalnej. Niezbędne są zatem takie metody, które wprost ilustrowałyby geografię podziałów społecznych i etnicznych (Johnston i inni 2009). Tym samym miary koncentracji przestrzennej na stałe weszły do kanonu badań nad lokalnymi wzorami segregacji. Najczęściej stosowaną spośród nich miarą jest prosty wskaźnik lokalizacji (location quotient) (Musterd i Deurloo 1997, Ellis i inni 2004, Chung i Brown 2007), który odnosi udział badanej grupy ludności do populacji danego miasta i odchylenia tego udziału od spodziewanych wartości (Węcławowicz 2003, s. 86) (4).

Wartości wskaźnika lokalizacji większe niż 1 oznaczają, że udział danej grupy społecznej lub etnicznej w określonej jednostce przestrzennej jest większy niż wartość średnia dla miasta. W badaniach przyjmuje się (chociaż zdania nie są jednomyślne), że wartość tego wskaźnika powyżej dwóch odchyleń standar- 
dowych oznacza koncentrację, a wartości większe niż trzy odchylenia standardowe oznaczają silną koncentrację (por. Marcińczak 2012).

$$
L Q=\frac{k X i / Y i}{k X / Y}
$$

gdzie:

$k X i$ - liczba ludności w grupie $k \mathrm{w}$ jednostce przestrzennej $i$;

$Y i$ - liczba ludności ogółem w jednostce przestrzennej $i$;

$k X$ - liczba ludności ogółem w grupie $k$ w mieście;

$Y$ - liczba ludności ogółem w mieście

W przypadku prowadzenia analiz z uwzględnieniem bardzo dużej liczby małych jednostek przestrzennych (dane agregowane do jednostek spisowych lub bloków urbanistycznych, których ogólna liczba wynosić może ponad 10 000) coraz częściej stosowne są lokalne wskaźniki autokorelacji przestrzennej (Johnston i inni 2011). Metody należące do tej grupy zaczerpnięte zostały z ekonometrii przestrzennej, a stosowane są do wyznaczania statystycznie istotnych skupień/klastrów (clusters) podobnych wartości zmiennej w sąsiadujących lokalizacjach (Suchecki i Olejnik 2010). Rodzina tych metod, chociaż zazwyczaj stosowana do analizy lokalnych wzorów koncentracji etnicznej (Brown i Chung 2006), w ostatnich latach $\mathrm{z}$ powodzeniem wykorzystywana była także w badaniach nad segregacją społeczną (Marcińczak i inni 2013a).

Na zakończenie rozważań dotyczących znaczenia i pomiaru segregacji raz jeszcze należy przypomnieć złożony charakter zjawiska. $Z$ tego też powodu, dla pełnego zrozumienia segregacji nieodzownym wydaje się być zidentyfikowanie procesów warunkujących rozwój i formę podziałów społeczno-przestrzennych. W równej mierze liczy się także analiza wzorów przestrzennych. Innymi słowy, w celu pełnej konceptualizacji problemu segregacji musimy poznać procesy, które są opisane wzorami, ale też i wzory, które ilustrują przebieg procesów. Kwestia pomiaru i opisu wzorów przestrzennych, które powinno odnosić się do dwóch podstawowych wymiarów (separacji i koncentracji), także wymaga szczególnej uwagi i szerokiego ujęcia. Ponadto warto podkreślić, że studia porównawcze wymagają stosowania jednostek przestrzennych możliwie jak najbardziej zbliżonych pod względem wielkości i liczby mieszkańców, gdyż wyniki 
miar segregacji uzależnione są od przyjętej delimitacji i podziału obszaru badań (Wong 2009). Analizy wykonywane dla mniejszych, a zatem bardziej homogenicznych jednostek przestrzennych, dostarczają wyższych wartości indeksów niż takie same obliczenia, prowadzone w bardziej ogólnym podziale przestrzennym (Wong 2009). Jeśli dostęp do podobnej przestrzennej agregacji danych nie jest możliwy, wnioski nasuwające się z badań porównawczych powinny być formułowane ostrożnie. Same badania empiryczne należy prowadzić w skali miasta (globalnej) i w skali sąsiedztw (lokalnej). 



\section{Rozdział 3}

\section{Segregacja społeczna w miastach epoki socjalizmu i po jej zakończeniu}

\section{Nierówności społeczne i segregacja przestrzenna w mieście socjalistycznym}

Proces urbanizacji socjalistycznej objął swoim zasięgiem obszar od Magdeburga do Władywostoku, a jego efekty zależne były od kontekstu społecznego, etnicznego, historycznego i gospodarczego (French i Hamilton 1979). Zasadniczym celem procesu urbanizacji $\mathrm{w}$ tym okresie było stworzenie społeczeństwa socjalistycznego (Miliutin 1974, Bater 1980), a miało to nastąpić na drodze forsownej industrializacji (Demko i Regulska 1987, Węcławowicz 1988). Zgodnie z założeniami ideologicznymi miasto socjalistyczne miało być egalitarne, jednakże okazało się być miejscem, w którym zróżnicowania społeczno-przestrzenne były wyjątkowo czytelne (Smith 1989, Węcławowicz 2002, Zborowski 2005, Marcińczak 2009). Nierówności społeczne manifestowane były nie tylko w przestrzeni ówczesnego miasta (Hamilton i Burnett 1979, Bater 1989, Dangschat 1987a, Szelényi 1987, Węcławowicz 1988) czy też w skali ośrodka i jego zaplecza (Szelényi 1983, Sjöberg 1991), ale także pomiędzy różnymi miastami (Fuchs i Demko 1979, French 1995). Podziałom na tle społeczno-zawodowym towarzyszyły również podziały na tle etnicznym (Rukavishnikov 1989, Ruble 1989, Kulu 2003, Ruoppila i Kährik 2003, Gentile i Tammaru 2006).

W pierwszych fazach okresu socjalistycznego istnienie czytelnych podziałów społeczno-przestrzennych, chociaż łagodniejszych niż przed 1945 rokiem, próbowano tłumaczyć dziedzictwem okresu presocjalistycznego (Pióro 1962, Piotrowski 1966, Węcławowicz 1975, Matejů i Večerník 1981). Jednak już na początku lat 1980. stało się oczywiste, że za nowymi wzorami podziałów społeczno-przestrzennych stoją procesy mające swoje źródło w funkcjonowaniu systemu socjalistycznego. Eliminacja własności prywatnej i zastąpienie jej przez całkowitą kontrolę państwa nad redystrybucją wszelkiego rodzaju dóbr (przede wszystkim mieszkań) oraz przywilejów, doprowadziła do znacznych nierówności społecznych już we wczesnych latach funkcjonowania systemu w dawnej ojczyźnie światowego proletariatu (Fitzpatrick 2012).

Jakie czynniki oddziaływały zatem na rozwój zjawiska segregacji społecznej przed 1989 rokiem? Wydaje się, że w początkowym okresie, ale także na późniejszych etapach rozwoju poprzedniego systemu, na formę podziałów społecznych i ich przestrzennej manifestacji, oprócz dominującej ideologii i towarzyszących jej instytucji wpłynęła gwałtowna industrializacja i związany z nią roz- 
wój miast. Bardzo szybko zostały one objęte ścisłą kontrolą meldunkową (Rykiel 1984, Morton 1984, Bater 1989), co w pewnym sensie pozbawiło społeczeństwo dostępu do tych ośrodków (Sjöberg 1994, Buckley 1995). Ciągłe niedobory gospodarki socjalistycznej (Kornai 1992) oraz priorytet nadany rozwojowi przemysłu (zwłaszcza ciężkiego) (Demko i Regulska 1987, Gaddy 1996) zaowocowały niedorozwojem innych sektorów, które uważano za mniej priorytetowe. W kontekście rozwoju struktury społeczno-przestrzennej miasta socjalistycznego najistotniejsze okazały się być ustawiczne braki mieszkaniowe oraz zastąpienie rynku mieszkaniowego przez politykę mieszkaniową (Szelényi 1983, Andrusz 1984, Węcławowicz 1998, Pásztor i Péter 2009).

W początkowych latach budowy socjalizmu warunki mieszkaniowe większości społeczeństw krajów socjalistycznych były tragiczne (French 1995). Najgorsze warunki oraz najsilniejsze podziały społeczne panowały w nowych miastach przemysłowych o czysto socjalistycznej genezie, w których do bardzo ograniczonych zasobów o relatywnie dobrych warunkach dostęp miała tylko garstka aparatczyków (nowej uprzywilejowanej kategorii społecznej). Dla przykładu, w Magnitogorsku w 1938 roku 47\% pomieszczeń mieszkalnych znajdowało się w barakach, a dalsze $18 \%$ stanowiły lepianki, sklecone przez samych mieszkańców z gliny, słomy i kawałków metalu (Fitzpatrick 2012, s. 70). W Dniepropietrowsku, mieście przemysłowym na Ukrainie, liczącym 400000 mieszkańców, do 1933 roku nie było kanalizacji (ibid.). W wielkich miastach o przedrewolucyjnej genezie zmorą stały się komunałki - mieszkania powstałe w wyniku nacjonalizacji istniejących zasobów mieszkaniowych, w których cała rodzina otrzymywała zazwyczaj jeden pokój, a reszta pomieszczeń, czyli kuchnia, łazienka i toaleta, były współużytkowane przez kilka rodzin. Ten typ mieszkania, barwnie i humorystycznie opisany w znanej powieści M. Bułhakowa (2012) Mistrz i Matgorzata, na stałe wszedł w krajobraz wielkich miast Rosji, również po upadku socjalizmu. Pomimo implementacji w zasadzie identycznych rozwiązań instytucjonalnych po 1945 roku, sytuacja wyglądała nieco lepiej w miastach poza dawnym Związkiem Radzieckim. W takich warunkach dostęp do zasobów mieszkaniowych o lepszym standardzie, biorąc pod uwagę formę i stopień zagęszczenia, stał się najistotniejszą kwestią dla większości gospodarstw domowych w mieście socjalistycznym.

Mechanizmy powstawania nierówności społeczno-przestrzennych w pierwszych dekadach socjalizmu poddane zostały wnikliwej analizie przez I. Szelényiego (1983). Stwierdził on, iż na Węgrzech w okresie funkcjonowania stalinowskich reżimów Mátyása Rákosiego i Ernő Gerő, wymuszona i szybka industrializacja doprowadziła do znacznych braków mieszkaniowych. Ograniczone zasoby poddane zostały ścisłej kontroli państwa, a ich racjonowanie ba- 
zowało na „ideologicznej” wartości siły roboczej (por. Węcławowicz 2003). Wyniki badań I. Szelényiego (1983), ale także analizy G. Węcławowicza (1975) prowadzone w Polsce wskazują, że dla ówczesnego systemu największe znaczenie miały dobrze wykształcone młode rodziny oraz członkowie nomenklatury (pracownicy aparatu partyjnego oraz służb bezpieczeństwa), co przekładało się na ich ułatwiony dostęp do najlepszych zasobów mieszkaniowych, oferowanych praktycznie wyłącznie przez sektor państwowy. Znacznie mniejsze szanse na zdobycie nowych mieszkań miała ludność starsza oraz gorzej wykształcona. W skali miasta doprowadziło to do zjawiska „niedourbanizowania” (underurbanization) (Murray and Szelényi 1984, Szelényi 1996), co w praktyce oznaczało niedobór zasobów mieszkaniowych $\mathrm{w}$ mieście $\mathrm{w}$ stosunku do zatrudnionej w nim siły roboczej (Tammaru 2001). Pamiętać także należy, że przy wprowadzonej kontroli meldunkowej sam dostęp do miast miał charakter selektywny (Morton 1984).

Podkreślenia wymaga także fakt, że ówczesny model „totalitarnego” państwa opiekuńczego, stanowiący pewien wariant typu „korporacyjnego” (Cerami 2010), bazował na miejscu pracy. Innymi słowy, dostęp do różnego rodzaju świadczeń społecznych uzależniony był nie tylko od samego faktu posiadania pracy, ale także jej charakteru i stopnia priorytetowości. Chociaż bezrobocie w zasadzie nie istniało, dostęp nielicznych grup społecznych (ludność starsza, osoby niepełnosprawne) do „zdobyczy” socjalistycznego państwa dobrobytu był ograniczony (Cerami 2006).

Sytuacja uległa niewielkiej poprawie w większości krajów socjalistycznych po 1968 roku, kiedy zakres państwa dobrobytu został rozszerzony. Miało to w głównej mierze na celu zapobieżenie niezadowoleniu społeczeństwa $\mathrm{z}$ warunków życia i sytuacji społeczno-politycznej po burzliwej końcówce lat 1960. (Cerami 2010). Szeroko zakrojony zakres państwa dobrobytu, między innymi bardzo mocno dotowany czynsz w zasobach komunalnych i spółdzielczych oraz kontrola płac, spowodował niski poziom rozwarstwienia w sferze dochodów ludności (Heyns 2005). Jednakże miejsce pracy i zawód nadal determinowały zakres, charakter i formę otrzymywanych świadczeń społecznych. W przypadku dostępu do zasobów mieszkaniowych miejsce zatrudnienia miało niebagatelne znacznie, gdyż zakłady pracy niejednokrotnie zapewniały mieszkania dla swoich pracowników (Gentile i Sjöberg 2010a). Pamiętając o tym, że różnym działom gospodarki oraz gałęziom przemysłu nadano różny priorytet, lepsze warunki mieszkaniowe (metraż, standard wykończenia mieszkania) przysługiwał pracownikom sektorów priorytetowych: przede wszystkim przemysłu ciężkiego i zbrojeniowego, ale także inteligencji technicznej i nie-technicznej oraz przedstawicielom nomenklatury (Smith 1996, Gentile i Sjöberg 2010b). Ludność pracująca 
poza sektorami uprzywilejowanymi była zdana na ograniczone zasoby komunalne o zdecydowanie niższym standardzie (Domański 1997).

W drugiej połowie okresu socjalistycznego, mniej więcej od połowy lat 1970., wciąż głoszone ideały społeczeństwa egalitarnego uległy daleko posuniętej erozji (Węcławowicz 1988). Jednak po trudnym okresie forsownej industrializacji warunki życia ludności znacznie się poprawiły (Cerami 2010). Wpływ miały na to dwa podstawowe czynniki związane z mieszkalnictwem. Pierwszym z nich było odejście od architektury socrealizmu, potępionej wraz $\mathrm{z}$,kultem jednostki” $\mathrm{w}$ tajnym referacie Nikity Chruszczowa na XX zjeździe KPZR w 1956 roku, a więc masywnych gmachów wznoszonych z cegły, w bardzo ograniczonych ilościach. Nowe mieszkania miały powstawać szybko, aby poprawić tragiczne warunki życia znacznej części mieszkańców wielkich miast, a tym samym zapewnić dalszą reprodukcję siły roboczej dla rozwijającego się przemysłu (French 1995). Odpowiedzią była typizacja i uprzemysłowienie architektury, a więc budowa wielkich, nieraz mających ponad 100000 mieszkańców, prefabrykowanych osiedli mieszkaniowych, zlokalizowanych poza centrami miast socjalistycznych (Basista 2001). Skupienie funduszy i siły roboczej na wznoszeniu prefabrykowanych osiedli przyczyniły się także do stopniowego upadku zabudowy śródmiejskiej, zwłaszcza przedwojennej tkanki mieszkaniowej, która poza nielicznymi wyjątkami pozbawiona była jakiejkolwiek odnowy.

Drugim czynnikiem związanym z ciągłymi i zwiększającymi się niedoborami w gospodarce centralnie sterowanej było zakończenie całkowitego monopolu państwa na finansowanie i przydział mieszkań. Chociaż budynki wciąż były wznoszone przez wielkie firmy państwowe, forma dostępu do zasobów uległa zasadniczej zmianie wraz z początkiem działania „pół-prywatnych” spółdzielni mieszkaniowych (Andrusz 1984, Bater 1989, French 1995), które wymagały partycypacji finansowej przyszłych mieszkańców (Ciechocińska 1987). W niektórych krajach (dobry przykład stanowią tu Bułgaria i Węgry) pod koniec okresu socjalistycznego większość nowo powstających zasobów stanowiły mieszkania prywatne w budynkach wielorodzinnych (Hegedüs i Tosics 1996, Tsenkova 2008). Z jednej strony można stwierdzić, że zwiększenie produkcji mieszkaniowej oraz wprowadzenie nowych form dostępu do zasobów przyczyniło się do częściowej poprawy sytuacji mieszkaniowej, cechującej się ciągłymi niedoborami. Niestety działania te nie wpłynęły na zasadnicze zmniejszenie nierówności w dostępie do nowych lokali mieszkalnych.

Na zakończenie rozważań na temat procesów segregacji w okresie socjalizmu należy silnie zaakcentować fakt, że system alokacji mieszkań w byłym Bloku Wschodnim był eksploatowany lub manipulowany przez osoby, które miały odpowiednie wpływy oraz koneksje (Morton 1984). Do podobnych wniosków 
doszli J. Bodnár i J. Böröcz (1998) opisując segmentację mieszkaniową na Węgrzech w okresie późnego socjalizmu. Ludność nie posiadająca takich wpływów musiała w celu realizacji swoich potrzeb mieszkaniowych próbować szczęścia w inny sposób, włącznie z korupcją (Morton 1984).

Podziały społeczno-przestrzenne w mieście socjalistycznym można zatem rozpatrywać, jako wynik działania w przestrzeni miasta różnych przedsiębiorstw i organizacji, zajmujących się przydziałem i produkcją mieszkań. Choć, według Batera (1989), w wyniku rozwoju tkanki mieszkaniowej w formie wielkich osiedli blokowych celem socjalistycznej klasy średniej stała się raczej sama przestrzeń mieszkaniowa, a nie jej lokalizacja w mieście, to jednak segregacja społeczna mieszkańców była obecna. W tym miejscu należy przypomnieć, że większość prac na temat wzorów przestrzennych nierówności społecznych w mieście socjalistycznym traktuje o strukturze społeczno-przestrzennej, która rozumiana jest jako zróżnicowania przestrzenne w rozmieszczeniu ludności o określonych cechach społecznych i danych warunkach zamieszkania (Węcławowicz 1988, s. 12). Tym samym opracowania te oddają ogólny obraz podziałów społecznych i warunków zamieszkania w przestrzeni miasta, ale nie dostarczają informacji o poziomie separacji i koncentracji różnych kategorii społecznych w mieście. Jednakże studia analizujące wzory segregacji społecznej per se także są obecne w literaturze przedmiotu.

W pierwszych dekadach okresu socjalistycznego wzory przestrzenne nierówności społecznych w znacznej mierze powielały obraz zróżnicowań społecznoprzestrzennych sprzed socjalizmu. Różnica polegała na tym, że w zasadzie poza byłym Związkiem Radzieckim zniknął aspekt etniczny wzorów przestrzennych (Pióro 1962, Piotrowski 1966) - wyjątkiem pozostali Romowie, zwłaszcza w miastach Węgier i Rumunii (drugi z wymienionych krajów cechował się także obecnością mniejszości węgierskiej i niemieckiej) (Turnock 2007). Innymi słowy, w zasadzie do początku lat 1960., przede wszystkim w miastach nieznacznie zniszczonych w wyniku działań II wojny światowej status społeczny mieszkańców malał wraz z oddalaniem się od centrum miasta. Wyjątek stanowiła tutaj strefa przejściowa, położona zaraz za centrum, która już przed wojną skupiała niższe kategorie społeczne (Szelényi 1983, Zborowski 2005). Sytuacja ta uległa jednak wyraźnej zmianie już na początku lat 1970., gdy kategorie wyższe i średnie zaczęły zajmować nowo powstające bloki, wznoszone albo w miejscach po zniszczonej zabudowie, albo na wolnych obszarach zaraz za strefą przejściową (Węcławowicz 1975, Matejů i Večerník 1981). Do ogólnego wzoru zróżnicowań społeczno-przestrzennych, układających się $\mathrm{w}$ formie koncentrycznych stref (Piotrowski 1966, Szelényi 1983, Zborowski 2005), dołączyły sektory tworzone przez nowe osiedla mieszkaniowe w strefie zewnętrznej, które zazwyczaj sku- 
piały wyższe i średnie kategorie społeczne (Sailer-Fliege 1999, Hamilton i Burnett 1979). Jednak już pod koniec lat 1970., oprócz pewnych regularności w postaci stref i sektorów, obraz struktury społeczno-przestrzennej wielkiego miasta socjalistycznego przypominał mozaikę (Węcławowicz 1988, Marcińczak i inni 2013a). Ponadto miasto socjalistyczne pozbawione było klasycznie rozumianej strefy podmiejskiej (French i Hamilton 1979, Tammaru 2001).

Model nierówności społeczno-przestrzennych zaproponowany przez I. Szelényiego (1983) do opisu zróżnicowań w pierwszych dekadach funkcjonowania byłego systemu nie do końca przystawał do faktycznych wzorów podziałów społeczno-przestrzennych tuż przed jego upadkiem. Główna jego modyfikacja dotyczyć powinna strefy zewnętrznej, gdzie osiedla nowych bloków (zwłaszcza te $z$ lat 1970. i 1980.) zasiedlone zostały przez lepiej sytuowanych mieszkańców i wyraźnie kontrastowały w przestrzeni z nierzadko substandardową zabudową o charakterze wiejskim, pochodzącą z okresu przedsocjalistycznego. Tym samym zaburzona została regularność strefy niskiego statusu społecznego.

Studia prezentujące wyniki analizy wzorów segregacji przestrzennej w mieście socjalistycznym pojawiły się w literaturze dopiero w końcu lat 1980. (i później) - odnosiły się do sytuacji w wielkich miastach na Węgrzech oraz w Polsce. $\mathrm{Z}$ uwagi na charakter stosowanych zmiennych (podział na główne kategorie społeczno-zawodowe) do porównań z krajami kapitalistycznymi najlepiej nadają się wyniki prac nad poziomem separacji społecznej w Budapeszcie w drugiej połowie okresu socjalistycznego. Badania nad wzorami segregacji społecznej w latach socjalizmu w największych miastach Polski prowadzone były przy użyciu tradycyjnych indeksów, ale stosowano inne zmienne w celu określenia statusu społecznego mieszkańców - najczęściej wykorzystywana była cecha „poziom wykształcenia” (Dangschat 1987a, Dangschat 1987b, Węcławowicz 1992, Marcińczak 2012, Marcińczak i inni 2013a). Pomimo różnych zestawów zmiennych oraz ograniczonej liczby prac, w których do opisu skali i poziomu podziałów społeczno-przestrzennych stosowano mierniki segregacji, dostępne rezultaty badań (przy założeniu pewnej uniwersalności procesów działających za byłą ,żelazną kurtyną”) pozwalają na wskazanie prawidłowości dotyczących natury wzorów segregacji społecznej w mieście socjalistycznym.

Porównując zatem poziom segregacji społecznej w wielkim mieście socjalistycznym z poziomem nierówności społeczno-zawodowych w wielkich miastach Europy Zachodniej i Stanów Zjednoczonych drugiej połowy XX wieku, stwierdzić można zasadnicze podobieństwa i różnice (rys. 2). Bez względu na panujący system społeczno-gospodarczy (socjalizm bądź kapitalizm), globalne wzory segregacji społecznej przyjmują uniwersalny kształt litery „U” - przy 
czym wyższe kategorie społeczno-zawodowe bywają bardziej odseparowane przestrzennie od reszty mieszkańców niż kategorie niższe.

Podstawowa różnica dotyczy natomiast poziomu separacji społecznej: podobnie jak i w przypadku skali nierówności społecznych (Heyns 2005), poziom segregacji (separacji) spolecznej ludności w mieście socjalistycznym byt niższy niż w mieście kapitalistycznym na podobnym etapie rozwoju przemyslowego (rys. 3).

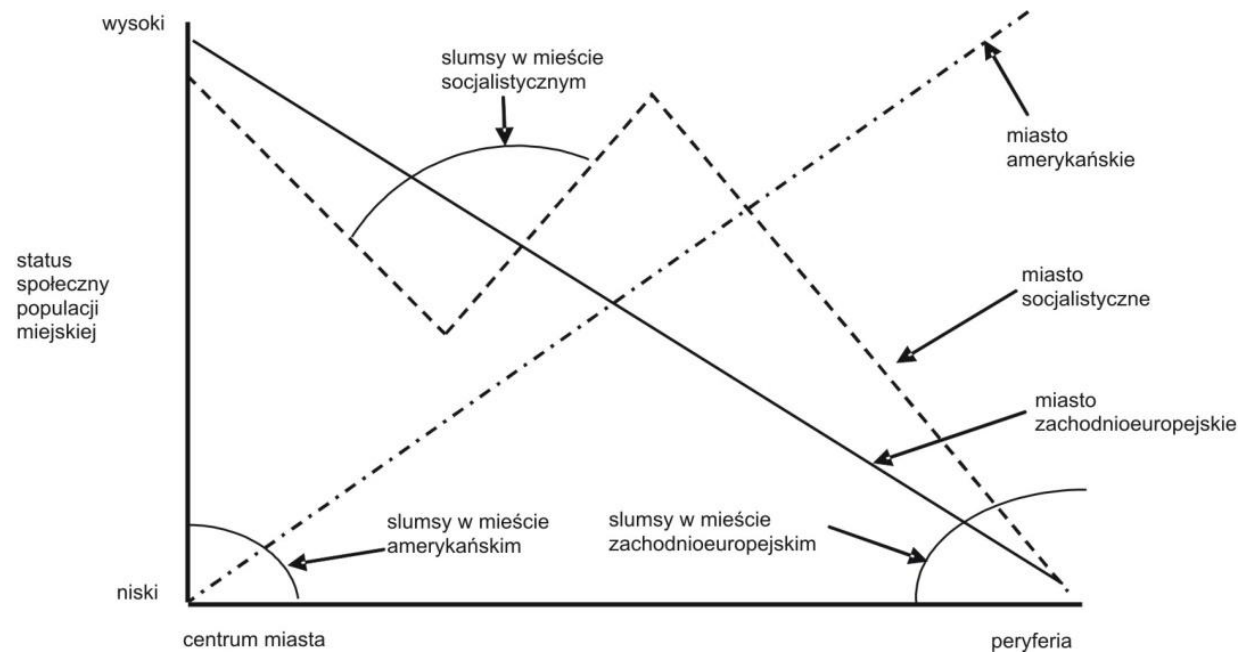

Rysunek 2: Schemat zróżnicowania społeczno-przestrzennego w mieście socjalistycznym i w miastach zachodnich Źródto: Szelényi 1983.

Pomimo wyraźnych różnic $\mathrm{w}$ poziomie separacji przestrzennej poszczególnych kategorii społeczno-zawodowych, ludność miasta socjalistycznego była także podzielona ze względu na poziom wykształcenia. Poziom separacji ludności z wykształceniem wyższym $(32,9)$ był większy niż w przypadku osób zatrudnionych jako specjaliści i kierownicy $(23,3)$. Co ciekawe, w zasadzie identyczne wartości poziomu separacji przestrzennej cechowały ludność z wykształceniem wyższym mieszkającą w Warszawie w 1970 roku (Dangschat 1987a).

Zakładając zatem, że zmienne dotyczące poziomu wykształcenia oraz/lub pozycji społeczno-zawodowej mieszkańców adekwatnie ilustrują podział ludności 
na główne grupy/kategorie społeczne, $\mathrm{z}$ dostępnych wyników badań wyłania się także określony trend zmian w poziomie segregacji społecznej w mieście socjalistycznym. Bez względu na to, w jaki sposób dokonano podziału na kategorie społeczne, poziom separacji przestrzennej poszczególnych grup spolecznych malat wraz z trwaniem systemu socjalistycznego. Wskazują na to zarówno wyniki badań nad zmianami we wzorach segregacji społeczno-zawodowej w Budapeszcie w latach 1970-1980 (Ladányi 1989), jak i analizy prowadzone w podobnym okresie (lata 1970 i 1978) w Warszawie, gdzie ludność klasyfikowano na grupy społeczne ze względu na poziom wykształcenia (Dangschat 1987a).

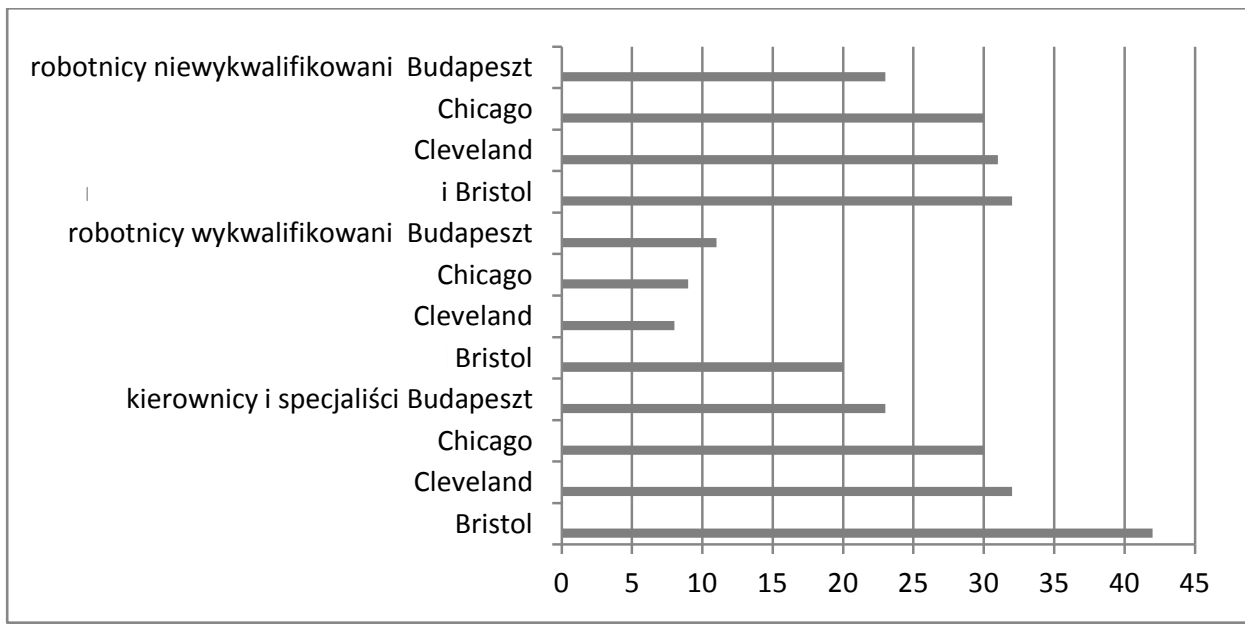

Rysunek 3: Indeksy segregacji dla wybranych kategorii społeczno-zawodowych w Bristolu (1966 rok), Budapeszcie (1970 rok), Chicago (1950 rok) i Cleveland (1950). Źródto: Opracowanie własne na podstawie: Morgan (1975), Ladányi (1989)

Identyczny trend cechował trzy największe miasta Polski (Warszawę, Łódź i Kraków) w ostatniej dekadzie systemu socjalistycznego (Marcińczak i inni 2013a). Innymi słowy, przynamniej od początku lat 1970. sąsiedztwa w wielkich miastach socjalistycznych stawały się coraz bardziej heterogeniczne społecznie, nawet w mikro-skali jednostek statystycznych (spisowych). Biorąc jednak pod uwagę, że miasta w tej części Europy odznaczały się znacznie silniejszymi podziałami społeczno-przestrzennymi przed II wojną światową (Węcławowicz 1975) oraz że w początkowym etapie funkcjonowania socjalizmu wzory spo- 
łeczne w znacznej mierze nawiązywały do tych sprzed wojny (Piotrowski 1966, Pióro 1962), trend cechujący dwie ostatnie dekady minionego systemu mógł mieć swoje początki znacznie wcześniej niż w 1970 roku.

Ostatnia z prawidłowości, jaką cechowały się wzory segregacji społecznej w mieście socjalistycznym, dotyczy różnic w poziomie separacji przestrzennej poszczególnych kategorii społecznych pomiędzy miastami o różnym profilu historyczno-funkcjonalnym. Niestety ten aspekt podziałów społeczno-przestrzennych w miastach byłego Bloku Wschodniego szczegółowo badany był jedynie w Polsce (Węcławowicz 1992, Marcińczak i inni 2013a). Dostępne opracowania sugerują złożoną naturę tego zjawiska. Wyniki otrzymane na podstawie pomiaru poziomu separacji przestrzennej ludności według poziomu wykształcenia w 1988 roku w trzech największych miastach Polski (Warszawa, Łódź, Kraków) w dwóch skalach przestrzennych (w jednostkach statystycznych i znacznie większych obszarowo, a zatem bardziej heterogenicznych społecznie jednostkach urbanistycznych) wskazują na bardzo intrygującą zależność pomiędzy typem miasta a formą podziałów społeczno-przestrzennych u schyłku okresu socjalistycznego. O ile w mikro-skali przestrzennej jednostek statystycznych różnice w poziomie separacji przestrzennej pomiędzy tymi miastami nie były w zasadzie widoczne, zmiana skali je uwypukliła (tab. 1).

Tabela 1: Indeksy segregacji dla ludności w podziale na grupy według poziomu wykształcenia w Warszawie, Łodzi i Krakowie, 1988 rok

\begin{tabular}{|l|c|c|c|c|c|c|c|c|}
\hline \multirow{3}{*}{ Miasto } & \multicolumn{8}{|c|}{ Ludność według poziomu wykształcenia } \\
\cline { 2 - 9 } & \multicolumn{2}{|c|}{ Wyższe } & \multicolumn{2}{c|}{ Średnie } & \multicolumn{2}{c|}{ zawodowe } & \multicolumn{2}{c|}{ Podstawowe } \\
\cline { 2 - 9 } & JS & JU & JS & JU & JS & JU & JS & JU \\
\hline Warszawa & 27,35 & 20,25 & 10,12 & 5,21 & 20,34 & 14,86 & 18,11 & 12,87 \\
\hline Łódź & 26,28 & 14,23 & 12,34 & 8,31 & 13,49 & 6,33 & 16,47 & 8,28 \\
\hline Kraków & 31,02 & 23,15 & 14,48 & 11,60 & 14,29 & 19,62 & 18,46 & 13,98 \\
\hline
\end{tabular}

JS - jednostki statystyczne; JU - jednostki urbanistyczne

Źródto: Opracowanie własne na podstawie G. Węctawowicz (1992) oraz Sz. Marcińczak i inni (2013a).

W związku z powyższym nasuwa się wniosek, że w bardziej zróżnicowanych funkcjonalnie miastach socjalistycznych podziały społeczne manifestowały się w większej skali przestrzennej niż w miastach typowo przemysłowych - nie w skali bloku urbanistycznego, ale raczej osiedla. 
Także w drugim z podstawowych wymiarów segregacji, jakim jest koncentracja, czytelne były różnice wynikające z profilu społeczno-gospodarczego miasta socjalistycznego (Marcińczak i inni 2013a). Zarówno w 1978, jak i w 1988 roku, poziom izolacji przestrzennej ludności z wykształceniem wyższym był najsilniejszy w Warszawie, a najsłabszy w Łodzi. Odwrotna zależność cechowała wzory koncentracji przestrzennej ludności z wykształceniem podstawowym.

Podobnie, jak i w przypadku poziomu separacji społeczno-przestrzennej, poziom koncentracji (izolacji poszczególnych grup społecznych) także malał w końcowej fazie funkcjonowania systemu socjalistycznego. Jednakże, pomimo generalnego trendu wskazującego na desegregację społeczno-przestrzenną, w Warszawie, Łodzi i Krakowie systematycznie wzrastał udział ludności z wykształceniem wyższym, zamieszkującej obszary, w których kategoria ta stanowiła ponad 30\% ogółu populacji (Marcińczak i inni 2013a). Na zakończenie z pewnym uogólnieniem można stwierdzić, że miasto socjalistyczne było relatywnie heterogeniczne społeczno-przestrzennie. Jednak segregacja poszczególnych kategorii ludności, przede wszystkim wyższych grup społecznych, była czytelna (chociaż niezbyt silna), a w wybranych aspektach wzrastała.

\section{Podziały społeczne i przestrzenne w miastach postsocjalistycznych}

Prawie pół wieku trwania systemu socjalistycznego wywarło trwałe piętno na społeczeństwach i przestrzeni krajów znajdujących się za byłą żelazną kurtyną. Raz jeszcze podkreślić należy, że w porównaniu z państwami kapitalistycznymi poziom nierówności społecznych w krajach socjalistycznych był znacznie niższy. Jednak $\mathrm{w}$ poprzednim systemie, przy prawie całkowitym braku działania mechanizmów wolnego rynku, nie dochód, ale dostęp do ograniczonych i kontrolowanych przez państwo zasobów był znacznie bardziej istotny w różnicowaniu społeczeństwa. W kontekście rozwoju zjawiska segregacji, egalitarny w teorii system socjalistyczny przyczynił się do powstania nieegalitarnego systemu alokacji mieszkań, który z kolei stał za produkcją i reprodukcją wzorów segregacji społeczno-zawodowej (Szelényi 1987, s. 7).

Pomimo czytelnych zróżnicowań społeczno-przestrzennych w mieście socjalistycznym, odznaczało się ono jednak niższym poziomem segregacji niż miasto kapitalistyczne. Początek lat 1990. oznaczał wejście miast byłego Bloku Wschodniego w radykalnie odmienny okres rozwoju, który oznaczał dogłębną zmianę zasad funkcjonowania społeczeństwa i rozwoju przestrzennego. Podstawy dla nowego porządku stworzył powrót wolnego rynku, własności prywatnej, samorządu terytorialnego, ale także szybkie objęcie byłych krajów socja- 
listycznych zasięgiem działania globalizacji oraz europeizacji. Innym ważnym czynnikiem była gwałtowna deindustrializacja, która także wywarła wpływ na nowe podziały społeczne (Węcławowicz 2003). Społeczno-gospodarcze i polityczne zmiany systemowe, zwłaszcza w krajach bałtyckich oraz Europie Środkowo-Wschodniej, zostały w zasadzie zakończone u schyłku lat 1990. (Deacon 2000). Dla większości byłych europejskich krajów socjalistycznych zwieńczeniem okresu trudów transformacji ustrojowej było wstąpienie do Unii Europejskiej w pierwszej dekadzie XXI wieku.

Jednak jeden kluczowy aspekt transformacji wymaga podkreślenia. Podczas gdy zmiana ustroju politycznego i wprowadzenie związanych z tym nowych rozwiązań instytucjonalnych zajęło stosunkowo niewiele czasu, zmiany w układzie osadniczym i przestrzeni miejskiej zajmą dekady (Sýkora 1999). Wynika to między innymi z faktu, iż ogół zmian społecznych w okresie transformacji ustrojowej w dużej części zachodził w strukturach przestrzennych odziedziczonych z poprzedniej epoki. Z kolei tempo adaptacji do zasad demokracji i wolnego rynku dyktowane było przez podejście każdego z byłych państw socjalistycznych do kwestii skali i charakteru transformacji systemowej (Åslund 2002). W skali regionalnej kontekst społeczno-gospodarczy miasta lub regionu miejskiego odgrywał zatem szczególną rolę $\mathrm{w}$ przebiegu, formie i charakterze zachodzących zmian (Gentile i inni 2012, Marcińczak i Sagan 2011, Sýkora i Bouzarovski 2012). Profil funkcjonalny miasta decydował o warunkach, na jakich dany ośrodek wszedł w globalną przestrzeń przepływów kapitału, inwestycji i ludzi (Marcińczak i inni 2012).

Podobnie jak w okresie socjalistycznym, rozwój regionalny w krajach postsocjalistycznych nie jest homogeniczny przestrzennie. Miastom stołecznym i innym wielkim ośrodkom miejskim o zróżnicowanej strukturze funkcjonalnej udało się skoncentrować większość nowych inwestycji zagranicznych oraz wzrostu gospodarczego (Enyédi 1994, Dunford i Smith 2000, Stenning 2004, Stanilov 2007, Smith i Swain 2010). Natomiast miasta przemysłowe, zwłaszcza te zdominowane przez jeden rodzaj przemysłu, z przestarzałą i zdegradowaną infrastrukturą, zanotowały załamanie gospodarcze, często związane z depopulacją (Węcławowicz 2004). W związku z kluczowym znaczeniem w hierarchii osadniczej oraz najszybszym tempem zmian, jak i największą ekspozycją na wpływy globalizacji, stolice państw postsocjalistycznych od samego początku były w awangardzie przemian (Węcławowicz 1998, Stenning 2004, Hamilton i inni 2005). W takich miastach duża dynamika zmian społecznych powinna szybko znaleźć swoje odbicie we wzorach przestrzennych.

Przyjmując, że poziom, skala, charakter i wzory segregacji społeczno-przestrzennej miasta/regionu są wyrazem dominującej struktury zatrudnienia lub sze- 
rzej rynku pracy (Scott 1988), podziały społeczno-przestrzenne po socjalizmie biorą się z jego nowej segmentacji. Sama segmentacja natomiast jest wynikiem restrukturyzacji gospodarki w warunkach globalizacji i związanego z nią nowego globalnego podziału pracy, jak również gwałtownej deindustrializacji i równoczesnej tertiaryzacji. W większości krajów postsocjalistycz-nych rynek pracy uformował się na nowo już w połowie lat 1990., a jego cechą szczególną był ogólny spadek aktywności ekonomicznej ludności (Bhalla i Lapeyre 2004, Rashid i inni 2005). Wzrastający udział osób wykluczonych z rynku pracy, a także wyraźne rozwarstwienie wynagrodzeń wśród pracujących, przyczyniły się do szybkiego wzrostu nierówności społecznych (Bandelj i Mahutga 2010, Stenning i inni 2010). Skalę nowych podziałów społecznych pogłębiło stopniowe kurczenie się zasięgu osłon socjalnych, dosyć rozległych w pierwszych latach transformacji (Cerami 2010), a także zasadnicze zmiany, polegające głównie na liberalizacji i urynkowieniu elementów dawnego państwa dobrobytu (Aidukaite 2011). Chociaż tempo i skala zmian bywają odmienne w poszczególnych państwach regionu (Rosati 2009), dotychczasowy kierunek ewolucji instytucjonalnej nie wskazuje, aby któryś z dawnych krajów socjalistycznych można było zakwalifikować do jednego z idealnych modeli państwa dobrobytu, znanych z krajów Europy Zachodniej (Aidukaite 2009).

Jak zatem wygląda wyłaniający się obraz nowych podziałów społecznych? Społeczeństwa postsocjalistyczne, biorąc pod uwagę charakter zmian na rynku pracy, można podzielić na dwie zasadnicze grupy: „wygranych” i „przegranych” procesu transformacji ustrojowej. Przy czym pamiętać należy, że podział ten nie jest symetryczny i oddziela wąską elitę od znacznie szerszej rzeszy tych, którzy na przemianach stracili (Węcławowicz 2004). Do grupy „wygranych”, a więc tych grup społecznych, których dochody oraz pozycja społeczna wzrosły, zalicza się wspomnianą elitę oraz nowo formującą się klasę średnią (Harloe 1996, Domański 2004). Kategoria ta jest jednak złożona - obok członków dawnej elity socjalistycznej i nomenklatury wyższego i średniego szczebla, w jej skład wchodzą także przedstawiciele inteligencji oraz opozycji antykomunistycznej (Węcławowicz 2002). Do grona „wygranych” należy także odmienna „demograficznie”, nowa wielkomiejska kategoria społeczna zwana „klasą metropolitalną” młodzi, dobrze wykształceni pracownicy, zatrudnieni w przemysłach wysokich technologii i kreatywnych (Jałowiecki 2000).

Na drugim końcu hierarchii społecznej wśród ludności pracującej znaleźli się robotnicy wykwalifikowani i niewykwalifikowani (Domański 2004, Węcławowicz 2002) oraz nisko opłacani pracownicy sektora usług, często zaliczani do kategorii „pracujących biednych” (working poor) (Smith i inni 2008). Jednak znaczna część „przegranych” pozostaje długotrwale bezrobotna lub została na 
stałe wykluczona z rynku pracy. Do powstania tej grupy przyczynił się upadek wielkich zakładów przemysłowych oraz niskie kwalifikacje zawodowe, a często także niski kapitał społeczny byłych pracowników, którzy okazali się „niedopasowani” do nowych wymogów globalnego kapitalizmu. Ludność ta, zmuszona do korzystania z zapomóg z uwagi na bardzo niski status materialny (ale także inne problemy społeczne), określana bywa mianem miejskiej underclass. Zjawisko to, zwłaszcza w wielkich miastach postsocjalistycznych doprowadziło do powstania wyraźnych enklaw biedy (Warzywoda-Kruszyńska i GrotowskaLeder 1996, Grotowska-Leder 2000). Jeszcze inną kategorią ,przegranych”, z uwagi na wysokość otrzymywanych świadczeń, pozostaje znaczna część ludności starszej (emeryci i renciści) (Węcławowicz 1998, Zborowski 2005).

Prezentowany obraz postsocjalistycznej transformacji w obrębie struktury społecznej ukazuje intrygującą formę nowych nierówności. O ile ogólny spadek aktywności ekonomicznej ludności, wzrost liczby osób pozostających czasowo lub trwale poza rynkiem pracy i pojawienie się wąskiej elity sugerować mogą charakter podziałów społecznych (polaryzacji społecznej) charakterystyczny dla koncepcji W. J. Wilsona (1987), o tyle przetasowania w obrębie społeczeństwa aktywnego zawodowo wskazują na bardziej skomplikowaną naturę zmian. Szybkie, a w większości krajów postsocjalistycznych wciąż rosnące rozwarstwienie wynagrodzeń, czyli charakterystyczna cecha globalnego kapitalizmu, wydaje się być odbiciem nierówności społeczno-materialnych w stylu tez S. Sassen (1991). Profil nowej hierarchii społecznej wymyka się zatem klasycznym modelom polaryzacji społecznej we współczesnym mieście kapitalistycznym. Wciąż jednak brakuje prac, które wprost zilustrowałyby kierunek zmian społeczno-zawodowych w wielkim mieście postsocjalistycznym, a zatem pozwoliły na porównanie konturów hierarchii społeczno-zawodowych w miastach krajów postsocjalistycznych z tymi, które znane są z miast Europy Zachodniej. Nieliczne prace, poruszające tę jakże istotną $\mathrm{w}$ kontekście rozwoju zjawiska segregacji kwestię (Hamnett 2001), wskazują raczej na proces profesjonalizacji struktury zatrudnionych, a więc trend podobny do stwierdzonego w wielkich metropoliach Europy Zachodniej (por. Hamnett 1994, 1998), a nie na polaryzację społeczną. Świadczy o tym chociażby kierunek zmian w strukturze społeczno-zawodowej Bukaresztu w latach 1992-2002, gdzie absolutny i relatywny wzrost liczby pracowników zaliczonych do wyższych kategorii („białe kołnierzyki”) nie wiązał się z równoległym wzrostem liczby zatrudnionych na stanowiskach niskopłatnych (Marcińczak i inni 2013b). Dół hierarchii społeczno-zawodowej, na skutek dramatycznego spadku zatrudnienia w przemyśle, skurczył się znacznie (ibid.). Kontur hierarchii społecznej w żaden sposób nie przypominał klepsydry - modelowego kształtu dla polaryzacji społecznej. Jak wskazują wyniki studiów prowadzonych 
w trzech największych miastach Polski, zróżnicowany profil funkcjonalny miasta i szybki rozwój po 1990 roku oznaczał większy udział wyższych kategorii społecznych w ogóle zatrudnionych oraz niższe bezrobocie. Odwrotna zależność cechowała miasto typowo przemysłowe, w którym baza ekonomiczna uległa załamaniu w początkowym okresie transformacji (Marcińczak i inni 2012).

Kolejnym ważnym czynnikiem, który wpłynął na rozwój zjawiska segregacji, były zasadnicze zmiany instytucjonalne $\mathrm{w}$ planowaniu przestrzennym oraz systemie mieszkaniowym. Nowe regulacje dotyczące zagospodarowania przestrzeni wprost wskazują na koniec ścisłej kontroli państwa nad rozwojem miasta. Do głosu doszła, często niczym nieograniczona, własność prywatna (Altrock i inni 2007, Marcińczak 2011). Efektem tych przekształceń, zwłaszcza w porównaniu z krajami Europy Zachodniej, był żywiołowy i chaotyczny proces urbanizacji, w większości kontrolowany przez rynek i prywatne prawa własności (Zanon i Marcińczak 2011). Kraje postsocjalistyczne zaczęły się zatem szybko upodabniać, a niekiedy nawet prześcignęły w kwestii deregulacji bardziej liberalnych w kwestiach planowania starych członków Unii Europejskiej (Halleux i inni 2012). Spośród wielu konsekwencji nowych rozwiązań instytucjonalnych w zakresie planowania przestrzennego, najistotniejsze w kwestii zmian we wzorach segregacji jest pojawienie się łatwo dostępnych działek budowlanych w strefie peryferyjnej i podmiejskiej miasta postsocjalistycznego.

Równie głębokie przekształcenia zaszły w formie, strukturze i funkcjonowaniu systemów mieszkaniowych w krajach byłego Bloku Wschodniego. Jak dobitnie ujął to M. Ball (2006), zmiany w zakresie mieszkalnictwa w krajach postsocjalistycznych zaliczyć należy do najbardziej dramatycznych na kontynencie europejskim w przeciągu kilku ostatnich dekad. Jednak pewne trendy, w tym rozwój prywatnych zasobów mieszkaniowych, rozpoczęły się już pod koniec okresu socjalistycznego (Węcławowicz 2003), a początek lat 1990. wielokrotnie je uwydatnit.

Wraz z krystalizacją samorządu lokalnego, na szczebel ten zepchniętych zostało wiele obowiązków, będących wcześniej domeną państwa. Jednym z największych ciężarów dla władz lokalnych były komunalne zasoby mieszkaniowe, które bardzo szybko zostały sprywatyzowane na rzecz zajmujących je mieszkańców, po cenach stanowiących jedynie cząstkę wartości rynkowej (Grime 1999, Ruoppila 2005). W tym miejscu warto zaznaczyć, iż w literaturze przeważały opinie głoszące, że szeroko zakrojona prywatyzacja zasobów mieszkaniowych okazała się najbardziej korzystna dla osób zamożnych oraz uprzywilejowanych w poprzednim systemie, które małym kosztem zdobyły znaczny kapitał (Bodnár 1994). Stąd też można wywnioskować, że zmiany własnościowe w zakresie zasobów mieszkaniowych przyczyniły się do nowych podziałów społecznych. 
W wyniku upadku socjalizmu oraz związanych z nim zmian w zakresie funkcjonowania państwa i gospodarki, odwróceniu uległ porządek w strukturze zasobów mieszkaniowych, które do początku XXI wieku, w przeważającej części krajów postsocjalistycznych znalazły się przede wszystkim w rękach prywatnych. Udział mieszkań prywatnych już na początku lat 2000. przewyższał w nich średnią dla Unii Europejskiej, jednakże nie wszędzie był taki sam. Krajami, w których rezydualizacja zasobów komunalnych była najmniejsza, a zasoby gminne nadal stanowią wyraźny udział ogółu mieszkań w miastach, są Polska i Republika Czeska (Lux i Sunega 2010). W krajach Europy PołudniowoWschodniej, gdzie już w okresie socjalistycznym dominowały „kontrolowane” zasoby prywatne (Bułgaria), doszło do sytuacji, gdzie własność prywatna stanowi ponad 90\% wszystkich mieszkań (Rumunia i Bułgaria) (Tsenkova 2008). Udział prywatnych zasobów mieszkaniowych wyraźnie dominuje też w krajach bałtyckich (Ball 2006). Oprócz prywatyzacji, do zmiany w strukturze własności zasobów przyczyniła się także we wszystkich krajach regionu restytucja mienia na rzecz dawnych właścicieli lub ich spadkobierców (Sýkora 1994, Blacksell i Born 2002, Dawidson 2004). Można także powiedzieć, że w przypadku kwestii mieszkaniowej nastąpiła radykalna liberalizacja tej sfery państwa opiekuńczego. W większości krajów postsocjalistycznych, przynajmniej w pierwszej dekadzie po upadku systemu, czynsze pozostały regulowane również w mieszkaniach odzyskanych przez dawnych właścicieli. Co ciekawe, liberalizacja systemu mieszkaniowego nie w każdym państwie postsocjalistycznym równała się z urynkowieniem innych elementów państwa opiekuńczego (Lis 2012).

Innym istotnym aspektem kwestii mieszkaniowej w mieście postsocjalistycznym są zmiany w strukturze inwestorów na rynku mieszkaniowym oraz produkcji nowych mieszkań. O ile w byłych krajach demokracji ludowej szczyt w budowie mieszkań przypadł na dwie ostatnie dekady trwania systemu, gdy inwestorem był jeszcze głównie sektor publiczny (w tym także zakłady przemysłowe), a za samą budowę odpowiedzialne były wielkie przedsiębiorstwa państwowe, o tyle rok 1990 wyznacza datę całkowitego odwrotu od tych prawidłowości. Innymi słowy liczba nowych mieszkań drastycznie spadła, udział sektora publicznego zmalał do nieistotnych rozmiarów, a nowe budynki wznoszone przez prywatne firmy deweloperskie oraz spółdzielnie mieszkaniowe sprzedawane są po cenach rynkowych tym, których na to stać (Pichler-Milanovic 1994, Węcławowicz 1998, Marszał 1999, Sagan 2000, Vesselinov 2004). Także globalizacja, zarówno prywatny kapitał, jak i imigranci (zwłaszcza menadżerowie międzynarodowych korporacji), wywierają coraz większy wpływ na produkcję i konsumpcję luksusowych mieszkań w szybko rozwijających się i atrakcyjnych miastach postsocjalistycznych (Cook 2010). Powyższe zmiany, a zwłaszcza 
szybki spadek zakresu dekomodyfikacji ${ }^{6}$ mieszkań, przyczyniły się zatem do pogłębienia podziałów społecznych.

Wzrost nierówności społecznych po upadku socjalizmu skłonił wielu badaczy do przyjęcia tezy o równoległym wzroście segregacji społecznej w przestrzeni wielkich miast w tej części Europy (Sailer-Fliege 1999, Węcławowicz 2002, Liszewski 2004, Brade i inni 2009, Polanska 2000). W przypadku Moskwy O. Vendina (1997, s. 362) stwierdziła, że „polaryzacja społeczna doprowadziła do silniejszych zróżnicowań społecznych”. Prawie dekadę później z podobną tezą wystąpili J. Temelova i inni (2011), badając zróżnicowania społeczno-przestrzenne osiedli mieszkaniowych w Republice Czeskiej. Jednak z drugiej strony wyniki badań z Bukaresztu w pierwszej dekadzie przemian wskazują na trend typowy dla profesjonalizacji (Marcińczak i inni 2013b). Polaryzacja społeczna nie powinna być zatem utożsamiana $\mathrm{z}$ relatywnie wysokim poziomem ubóstwa w byłych krajach postsocjalistycznych. Odmienne stanowisko reprezentują S. Ruopilla i A. Kährik (2003). W przypadku analizy struktury społeczno-przestrzennej Tallinna doszli oni do wniosku, że pomimo gwałtownych zmian społecznych miasto postsocjalistyczne jest nadal heterogeniczne przestrzennie, a mobilność mieszkaniowa była niska. Autorzy nie przewidywali także znacznych zmian w tym zakresie w nadchodzących latach.

Oprócz tez o wzroście segregacji społeczno przestrzennej oraz tych, które można by określić, jako głos przemawiający za brakiem zasadniczych zmian, w ostatnich latach pojawiły się argumenty przemawiające za spadkiem poziomu segregacji społecznej w wielkich miastach postsocjalistycznych po 1990 roku (Sýkora 2007, Marcińczak 2012), co jest zaskakujące w kontekście faktycznego wzrostu nierówności społecznych. Argumentację tą można określić mianem „ewolucyjnej”, gdyż zakłada, że procesy suburbanizacji oraz gentryfikacji w mieście postsocjalistycznym, podobnie jak miało to miejsce w miastach kapitalistycznych, gdzie działają one od dawna (por. Freeman 2009), czasowo niwelują poziom podziałów społecznych w skali sąsiedztw. Tezy o „ewolucyjnej” naturze segregacji społecznej po socjalizmie mają sens tak długo, jak przyjmujemy, że miasta w byłych krajach Bloku Wschodniego są w zasadzie podobne i zmierzają w kierunku modeli znanych z Europy Zachodniej.

${ }^{6}$ Dekomodyfikacja oznacza takie przekształcenie dóbr i usług świadczonych w ramach uprawnień socjalnych, że tracą one swoją wartość rynkową i jednocześnie zmieniają układ stratyfikacyjny społeczeństwa. Wysoki udział prywatnych zasobów mieszkaniowych oznacza niską dekomodyfikację oraz, z uwagi na fakt, że większość osób musi kupić mieszkanie, przyczynia się do silniejszych zróżnicowań społecznych (Lis 2012). 
Bez względu na powyższe propozycje dotyczące poziomu segregacji społecznej po 1990 roku (wzrost, brak zmian, czy spadek), wciąż bardzo mało wiadomo o wzorach segregacji społecznej w miastach byłych krajów socjalistycznych, a badania prowadzone $\mathrm{w}$ zgodzie $\mathrm{z}$ ogólnie przyjętymi metodami pomiaru zjawiska pojawiły się dopiero po 2000 roku (Sýkora 2007, 2009, Tátrai 2011, Marcińczak 2012, Marcińczak i inni 2012, Marcińczak i inni 2013a, Marcińczak i inni 2013b). Jednak nawet te prace powstałe w ostatnich dwóch dekadach, które nie stosują indeksów segregacji, dostarczają cennej wiedzy o procesach operujących w miastach po upadku socjalizmu oraz o zmianach w ogólnym obrazie struktury społeczno-przestrzennej miasta. Przed przystąpieniem do dokładniejszego przeglądu prac na temat podziałów społeczno-przestrzennych w miastach postsocjalistycznych należy podkreślić, że podobnie w przypadku ośrodków z okresu socjalistycznego, stan wiedzy jest selektywny geograficznie - znacznie więcej wiadomo o miastach, przede wszystkim stołecznych, Polski, Czech i Węgier niż o ośrodkach Europy Południowo-Wschodniej, zwłaszcza położonych niżej w hierarchii osadniczej (Marcińczak i Sagan 2011, Gentile i inni 2012, Sýkora i Bouzarovski 2012).

Badania nad przemianami społeczno-przestrzennymi w mieście postsocjalistycznym pozwalają wyróżnić sześć głównych zjawisk, które w znacznej mierze kształtują zmieniające się wzory segregacji społecznej w miastach i regionach miejskich w byłym Bloku Wschodnim. Według Sz. Marcińczaka i innych (2013a), do podstawowych procesów kształtujących wzory segregacji społecznej należą:

1. Gentryfikacja i wynikające z niej zmiany społeczno-przestrzenne,

2. Deindustrializacja oraz związane $\mathrm{z}$ nią odnowa/rewitalizacja terenów poprzemysłowych oraz komercjalizacja strefy wewnętrznej,

3. Suburbanizacja oraz przemiany społeczne na obszarach peryferyjnych w granicach administracyjnych,

4. Powstawanie osiedli grodzonych oraz inne elementy separacji przestrzennej wyższych kategorii społecznych,

5. Obniżanie się statusu społecznego wielkich osiedli mieszkaniowych,

6. Zmiany społeczne wywołane „drugim przejściem demograficznym”.

Zakres działania tych procesów jest odmienny przestrzennie, niektóre obejmują swoim zasięgiem całe miasto/region, inne ograniczają się jedynie do wybranych stref. $\mathrm{W}$ tym miejscu raz jeszcze należy podkreślić wybiórczość wiedzy o przeobrażeniach społeczno-przestrzennych w granicach miast/regionów byłych krajów demokracji ludowej. Otóż znacznie więcej wiemy o procesach suburbanizacji oraz o zmianach w centrach (strefach wewnętrznych) wielkich miast postsocjalistycznych, niż o tym, co wydarzyło się z sektorami wielkich osiedli 
blokowych, a także socjalistyczną strefą przejściową (Borén i Gentile 2007, Marcińczak 2009).

Centra miast postsocjalistycznych oraz otaczająca je strefa wewnętrzna były miejscem, gdzie zmiany związane $\mathrm{z}$ wprowadzeniem kapitalizmu pojawiły się najszybciej. Jak celnie podsumowuje to Danta (1993), w Bukareszcie, gdy nie do końca opadł jeszcze kurz po rewolucji związanej z obaleniem N. Ceauşescu, na niedokończonych monumentalnych budynkach w centrum miasta, które miały unieśmiertelnić dyktatora, zawisły reklamy firmy „Kodak”. Oprócz czysto kosmetycznych zmian związanych z pierwszymi latami okresu transformacji ustrojowej, w centrach miast, a także strefach wewnętrznych, czytelne było działanie procesów gentryfikacji oraz rewitalizacji. O ile rewitalizacja oznacza głównie odnowę zabudowy (Kaczmarek 2004), gentryfikacja wiąże się, przynajmniej w tradycyjnym rozumieniu (por. Glass 1964), z wymianą składu mieszkańców i wzrostem statusu społecznego danego miejsca. Obszary centralne miast, niedoinwestowane w okresie socjalizmu, popadały w ruinę oraz stopniowo obniżał się ich status społeczny. Było to szczególnie wyraźne w tych miastach, w których zabudowa śródmiejska o przedsocjalistycznej genezie nie uległa zniszczeniom w okresie II wojny światowej. Po roku 1990 tereny te na nowo stały się obszarem prestiżowym i wizytówką miasta. Jednak skala i zakres procesów gentryfikacji i rewitalizacji w mieście postsocjalistycznym wciąż wydają się być ograniczone, a o samych zjawiskach nadal nie wiemy zbyt wiele (Grzeszczak 2010).

Efekty procesów gentryfikacji najbardziej widoczne są w stolicach państw postsocjalistycznych (Węcławowicz 1998, Sýkora 2005). Jednak zarówno tam, jak i w miastach położonych niżej w hierarchii osadniczej (por. Zborowski 2005, Murzyn 2006, Marcińczak 2009, Liszewski i Marcińczak 2012), efekty działania procesów gentryfikacji manifestują się w skali pojedynczych budynków lub działek urbanistycznych i często wymieszane są z terenami zdegradowanymi lub zamieszkanymi przez niskie kategorie społeczne (Badyina i Golubchikov 2005, Kowalski i Śleszyński 2006, Jadach-Sepioło 2007, Brade i inni 2009, Kovács 2009). Ponadto gentryfikacja częściej oznacza wznoszenie nowych budynków kosztem starej tkanki, niż odnowę zabudowy istniejącej (Kovács i inni 2012). W kontekście czynników sprawczych, proces uszlachetniania społecznego i przestrzennego był inicjowany „od dołu”, przez pojedyncze osoby (gospodarstwa domowe) lub grupy osób (Chelcea 2006, Grabkowska 2011), ale też „od góry”, w ramach projektów odnowy, forsowanych przez samorządy lokalne przy wsparciu prywatnego kapitału (Feldman 2000, Sagan 2000, Bernt 2009).

Proces rewitalizacji dzielnic centralnych związany jest często z odnową zdegradowanych terenów przemysłowych oraz komercjalizacją (Kiss 2002, Kaczmarek 2004, Sýkora 1999, Zborowski 2009). Odnowa przestrzeni śródmiejskiej 
nierzadko wiąże się z realizacją tzw.: ,projektów flagowych”, czyli obiektów unikalnych architektonicznie lub ciekawych aranżacji na bazie zabudowy istniejącej (Temelová 2007). Działania te w przeważającej części finansowane są przez kapitał prywatny, jednak udział kapitału publicznego wzrósł znacznie po wstąpieniu wielu krajów do Unii Europejskiej. Rewitalizacja oraz szeroko pojęta odnowa często wiąże się z wymianą składu społecznego (uszlachetnieniem społecznym) i przyczynia do zajęcia danego obszaru (chociaż czasem może być to jedynie blok urbanistyczny) przez ludność lepiej sytuowaną (Kaczmarek i Marcińczak 2013). W przypadku nowych centrów handlowych lokowanych wśród zdegradowanej zabudowy dochodzi zazwyczaj do czaso-przestrzennej segregacji, gdy wyższe kategorie społeczne tylko w określonych porach przebywają na obszarach o niskim statusie społecznym (Marcińczak 2009).

Jeszcze inną cechą dzielnic śródmiejskich są enklawy biedy, będące efektem wykluczenia społecznego ,przegranych" w procesie transformacji ustrojowej. Wydaje się, że klasycznym przykładem są rezydualne, śródmiejskie komunalne zasoby mieszkaniowe. Zazwyczaj są to stare, substandardowe kamienice, które w okresie socjalistycznym zajęte były przez niższe kategorie społeczne (Warzywoda-Kruszyńska i Grotowska-Leder 1996, Grotowska-Leder 2000, Węcławowicz 2001, Zborowski 2005, Marcińczak 2009). W przypadku Tallinna była to stara, śródmiejska drewniana zabudowa o bardzo niskim standardzie, relatywnie odseparowana przestrzennie od reszty centrum (Ruopilla i Kährik 2003). Wyniki analiz z miast Europy Południowo-Wschodniej z kolei wskazują, że wykluczeni społecznie mogą także nielegalnie zajmować opuszczoną śródmiejską zabudowę, jak ma to miejsce w przypadku ludności romskiej w Bukareszcie (Chelcea 2006, Marcińczak i inni 2013b). Innymi enklawami biedy w tym mieście, przez miejscowych badaczy nazywane „gettami”, były opuszczone bloki oraz dawne hotele robotnicze o bardzo niskim standardzie, zajęte przez grupy zmarginalizowane społecznie (Mionel i Neguţ 2011).

Wielkie osiedla mieszkaniowe, wytwór epoki socjalizmu, realizowane były zazwyczaj w formie gęstej zabudowy wielorodzinnej, ciągnącej się wzdłuż głównych arterii komunikacyjnych i dzielnic przemysłowo-składowych. Rozmiary niektórych z nich przekraczały 100000 mieszkańców - osiedla takiej wielkości powstały przede wszystkim w drugiej dekadzie okresu socjalistycznego (French 1995). We wcześniejszym okresie mniejsze osiedla wznoszone były w obrębie strefy śródmiejskiej lub, w przypadku znacznych zniszczeń wojennych, także w pobliżu centrum. Należy pamiętać, że w socjalizmie ta forma zabudowy (zwłaszcza zasoby spółdzielcze) skupiała ówczesną klasę średnią (Szelényi 1983, Węcławowicz 1988, Zborowski 2005, Marcińczak 2009). Jednak niektórzy badacze przewidywali, że w miastach postsocjalistycznych osiedla 
z wielkiej płyty staną się slumsami XXI wieku (Szelényi 1996). Chociaż ta część miast postsocjalistycznych $\mathrm{z}$ reguły pozostawała poza głównym nurtem badań empirycznych (Marcińczak i Sagan 2011), dostępne wyniki, poza kilkoma wyjątkami, nie pozwalają na przyjęcie tezy o upadku społecznym wielkich kompleksów mieszkaniowych. Chociaż obszary te w skali pojedynczych mieszkań lub budynków pozostają heterogenicznie społecznie (Temelová i inni 2011), to mimo wszystko, jako jedna z głównych składowych struktury społeczno-przestrzennej miasta postsocjalistycznego, nadal pozostają w dużej mierze zajęte przez szeroko pojęte średnie, a także wyższe kategorie społeczne (zależnie od lokalizacji i standardu) (Ruopilla i Kährik 2003, Zborowski 2005, Marcińczak 2009, Kährik i Tammaru 2010).

O ile w poprawę standardu technicznego osiedli blokowych w miastach krajów Europy Środkowo-Wschodniej i państw bałtyckich aktywnie zaangażował się sektor publiczny i spółdzielnie mieszkaniowe, w krajach Europy Południowo-Wschodniej, gdzie prawie całość zasobów pozostaje w rękach prywatnych, ciężar ten spadł na pojedynczych mieszkańców i gospodarstwa domowe (Bouzarovski i inni 2011, Soaita 2012). Na obszarach tych dochodzi także do dogęszczania zabudowy przez nowe inwestycje deweloperskie, co oprócz ogólnie niskiej mobilności mieszkaniowej w miastach postsocjalistycznych pierwszej dekady zmian (Mandič 2001), przyczynia się do utrwalenia średniego/wyższego statusu osiedli blokowych.

Zjawisko suburbanizacji, nieznane w klasycznym znaczeniu w miastach socjalistycznych, wydaje się być najczęściej podejmowanym tematem studiów nad zmianami $w$ strukturze społeczno-przestrzennej miast i regionów miejskich. W kontekście badań nad segregacją K. Leetmaa i inni (2009) postuluje, że proces ten ma kluczowe znaczenie w formowaniu krajobrazu społecznego regionów miejskich w krajach postsocjalistycznych. Bez wątpienia rozrost stref podmiejskich wielkich miast stał się cechą charakterystyczną postsocjalistycznej urbanizacji (Jakóbczyk-Gryszkiewicz i inni 2010). Jednak migracja na tereny podmiejskie nie była ograniczona do wybranej kategorii społecznej, a związany z nią krajobraz nie zawsze przypominał ten znany z miast Europy Zachodniej. Chociaż w strukturze nowych mieszkańców postsocjalistycznych suburbiów przeważają średnie i wyższe kategorie społeczne (Leetmaa i Tammaru 2007, Hirt 2007, Novák i Sýkora 2007, Ouředníček 2007), to na obszary te, zwłaszcza w początkowej fazie transformacji, skierowały się także osoby gorzej sytuowane materialnie (Kok i Kovács 1999). Przemieszczenia te, występujące zwłaszcza w miastach Europy Południowo-Wschodniej, przejawiały się powstawaniem peryferyjnych slumsów (Deda i Tsenkova 2006). Z terenami podmiejskimi związane jest także powstawanie coraz liczniejszych osiedli grodzonych dla nowej 
elity (Marin 2005, Blinnikov i inni 2006, Stoyanov i Frants 2006, Kostreš i Reba 2010, Hirt 2012). Jednak projekty mieszkaniowe tego typu, zwłaszcza „nisze” dla zagranicznych menadżerów zatrudnionych czasowo (nierzadko jest to kilka lat) przy projektach $\mathrm{z}$ zaangażowaniem kapitału globalnego, powstają także w centrach stolic krajów postsocjalistycznych (Cook 2010).

Ostatnim z procesów, dotyczących przemian w obrębie struktury demograficznej mieszkańców wielkich miast postsocjalistycznych, ale mających także czytelne efekty w przestrzeni społecznej, jest drugie przejście demograficzne (van de Kaa 1987). Głębokie zmiany we współczesnych społeczeństwach krajów wysoko rozwiniętych prowadzą do przemian w strukturze gospodarstw domowych. W istocie rośnie liczba gospodarstw jednoosobowych, ale też gospodarstw niestandardowych (pary nie posiadające dzieci), a maleje liczba ludności. Proces ten wydaje się być dostrzegalny także w miastach postsocjalistycznych (Steinführer i Haase 2007), zwłaszcza pamiętając o tym, że w większości krajów regionu dominuje ujemny przyrost naturalny. Obszarami, w których zmiany są najbardziej widoczne, wydają się być tereny śródmiejskie, które postrzegane są jako coraz bardziej atrakcyjne, zwłaszcza przez ludność młodą i bezdzietną (Kabisch i Sagan 2011). Zjawisko to przyczynia się zatem do oddolnej gentryfikacji (Grabkowska 2012).

Studia poświęcone ewolucji struktury społeczno-przestrzennej miast postsocjalistycznych dostarczają cennego opisu ogólnego obrazu podziałów społecznych. W tym miejscu należy dodać, że oprócz nielicznych prac opisowych, dominowały studia utrzymane $\mathrm{w}$ duchu tradycji ekologii społecznej, co rzutowało na wykorzystanie różnych technik statystyki wielowymiarowej do poszukiwania „klasycznych” regularności w kształcie zróżnicowań społeczno-przestrzennych. Biorąc pod uwagę rozmiar byłego Bloku Wschodniego, wyniki badań nie pozwalają na inną generalizację niż ta, że centra miejskie często zamieszkane były przez ludność starszą oraz niższe kategorie społeczne (Marcińczak i inni 2013b). Tę prawidłowość zasadniczo potwierdzają wyniki z miast polskich (Zborowski 2005, Marcińczak 2009, Smętkowski 2009), ale także z Estonii (Ruopilla i Kährik 2003), Czech (Sýkora 1999) i Rumunii, chociaż w tym wypadku poziom zróżnicowań społeczno-przestrzennych uważany był za słaby (Petrovici 2012, Rufat 2012). W miastach tych obszary centralne posiadały ogólnie niski lub średni status społeczny, który rósł w obszarach wielkich osiedli mieszkaniowych, by drastycznie zmaleć w strefie peryferyjnej, choć w tej ostatniej spodziewano się szybkiego wzrostu udziału ludności zamożnej. Rezultaty analizy czynnikowej dla Zagrzebia na początku lat 2000. wskazują, że układ struktury społeczno-przestrzennej nawiązywał do modelu sektorowego (Prelogović 2009). Wyniki badań przeprowadzonych w tym mieście, ale dodatkowo 
także w Splicie, dowodzą spadku statusu społecznego (mierzonego poziomem wykształcenia $\mathrm{w}$ nieco mniej dokładnym podziale przestrzennym) wraz z oddalaniem się od centrum (Speveć i Klempić-Bogadi 2009). Zatem nie sposób oprzeć się stwierdzeniu, że klasyczny już model zróżnicowań społecznoprzestrzennych w tej części Europy (Szelényi 1983) oraz jego modyfikacje wywołane trendami w rozwoju zasobów mieszkaniowych późnej fazy socjalizmu (przede wszystkim zagospodarowanie strefy przejściowej wczesnego miasta socjalistycznego przez osiedla blokowe, przy jednoczesnym upadku centrum), należy poddać dalszej analizie, w celu wskazania możliwych kierunków zmian wywołanych transformacją ustrojową. Propozycję nowych tendencji w ogólnym rozwoju struktury społeczno-przestrzennej miasta postsocjalistycznego przedstawia rysunek 4.

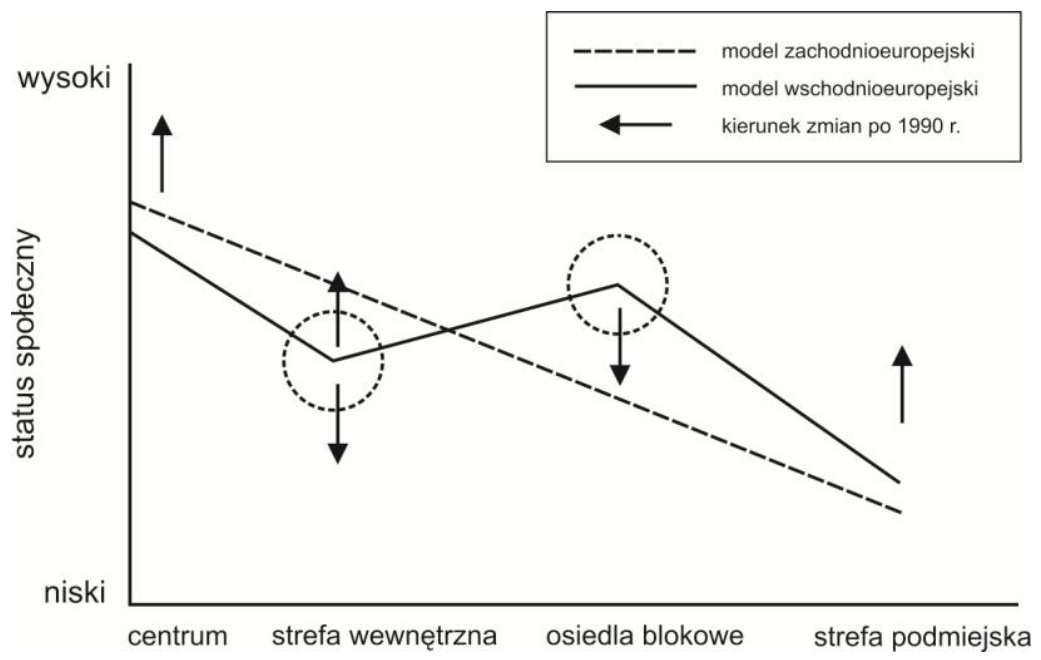

Rysunek 4: Zmiany statusu społecznego z odległością od centrum miasta Źródto: opracowanie własne na podstawie: Kovacs and Herfert (2012)

Jak już było to wspomniane powyżej, wciąż brakuje prac, które ilustrowałyby zmiany w poziomie i wzorach przestrzennych segregacji społecznej w miastach po socjalizmie. O ile same procesy zostały zidentyfikowane i opisane dosyć szybko, prace bazujące na solidnych danych empirycznych i adekwatnych metodach pomiaru pojawiły się dopiero pod koniec pierwszej dekady XXI wieku. Badania prowadzone $\mathrm{w}$ wielkich miastach i regionach miejskich Polski i Repub- 
liki Czeskiej w pierwszej dekadzie zmian systemowych wskazują na spadek poziomu separacji i izolacji społecznej w skali małych, relatywnie homogenicznych morfologicznie jednostek przestrzennych (Sýkora 2007, Marcińczak 2012). Innymi słowy zmiany w poziomie segregacji społecznej wskazują na coraz większą równomierność w rozmieszczeniu różnych grup społecznych. W strefie podmiejskiej tereny o niskim statusie społecznym poddawane są żywiołowej suburbanizacji, na czele której stoi nowa klasa średnia, co w efekcie prowadzi do (czasowego?) wzrostu heterogeniczności społecznej tych obszarów (Marcińczak 2012). Rosnące wymieszanie społeczne cechuje także miasta w granicach administracyjnych. Podobnych rezultatów, jednak przy znacznie niższym poziomie desegregacji, dostarcza praca nad nierównościami społecznoprzestrzennymi w Bukareszcie (Marcińczak i inni 2013b).

Badania nad wzorami segregacji społeczno-zawodowej $\mathrm{w}$ trzech największych miastach Polski w 2002 roku wskazały na istnienie drugiego paradoksu segregacji postsocjalistycznej (Marcińczak i inni 2012). Otóż pomimo zasadniczo odmiennych profili historyczno-gospodarczych oraz ścieżek rozwoju po upadku systemu, poziom separacji przestrzennej grup społeczno-zawodowych mierzony indeksem segregacji nie różnił się zasadniczo w Warszawie, Łodzi i Krakowie. Istotne różnice odnotowano zwłaszcza we wzorach koncentracji poszczególnych kategorii społecznych. Wyższe kategorie najczęściej zamieszkiwały w obszarach koncentracji przestrzennej w Warszawie, a najrzadziej w Łodzi. Odwrotna zależność cechowała kategorie niższe. Co ciekawe, lokalnym wzorom koncentracji przestrzennej towarzyszyła czytelna segmentacja mieszkaniowa. Biorąc pod uwagę strukturę własnościową oraz formę zabudowy można stwierdzić, że wyższe kategorie społeczne przede wszystkim zajmowały zasoby spółdzielcze oraz prywatne, które powstały w ostatnich dwóch dekadach socjalizmu oraz po 1990 roku. Ludność z niższych grup społecznych zamieszkiwała z kolei przede wszystkim w komunalnych lub sprywatyzowanych mieszkaniach w starej, przedwojennej tkance dzielnic śródmiejskich. Wyjątek od tej reguły stanowiły presocjalistyczne osiedla willowe oraz luksusowe kamienice w centrum.

Wyniki najnowszych i jak dotąd najpełniejszych badań, które uwzględniają także ostatnią dekadę epoki socjalistycznej, stawiają kwestię ,paradoksu” segregacji w miastach byłego Bloku Wschodniego w nowym świetle (Marcińczak i inni 2013a). Spadek poziomu separacji społecznej mierzony w podziale ludności według wykształcenia malał też w ostatniej dekadzie systemu socjalistycznego. W okresie tym, podobnie do trendu cechującego fazę postsocjalistyczną, poziom koncentracji wyższych grup społecznych systematycznie rósł, a niższych malał (tab. 2), przy czym zależności te były najbardziej wyraźne w najprężniej rozwijającym się mieście, czyli w Warszawie. 


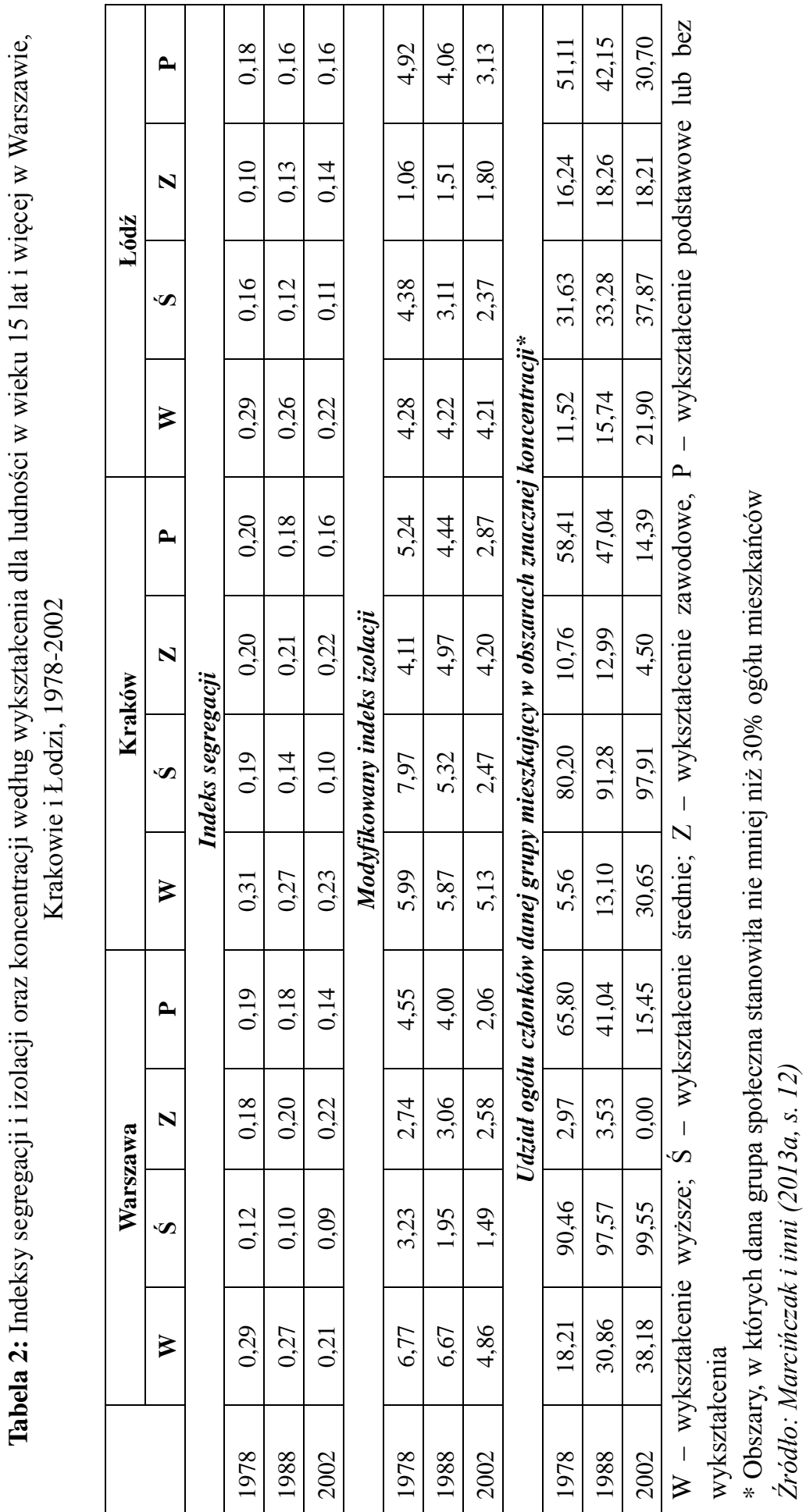


Rezultaty powyższej pracy oraz innych dostępnych studiów pozwalają na wskazanie pewnych prawidłowości, dotyczących ewolucji wzorów segregacji społecznej w miastach postsocjalistycznej Europy. Najważniejszym, oprócz wykrycia „paradoksu” lub „paradoksów” segregacji społecznej, jest fakt, że w pierwszej dekadzie transformacji ustrojowej nie nastąpiły zasadnicze zmiany w kierunku ewolucji podziałów społeczno-przestrzennych. Innymi słowy, pomimo względnej i rosnącej równomierności w rozlokowaniu kategorii społecznych, ludność lepiej uposażona coraz bardziej oddzielała się od reszty, zamieszkując we własnych enklawach. Ponadto, zarówno u schyłku poprzedniego systemu, ale też $\mathrm{w}$ okresie transformacji ustrojowej, obszary o wyższym statusie społecznym oddalały się od centrum. Trendy te były czytelne w miastach o różnym profilu funkcjonalnym i pozycji w hierarchii osadniczej.

Biorąc pod uwagę selektywność przestrzenną procesów kształtujących wzory segregacji społecznej, w literaturze wciąż brakuje opracowań, które, oprócz pomiaru poziomu segregacji w skali całego miasta, pozwoliłby także wejrzeć w skalę podziałów społecznych w trzech głównych strefach miast w byłych krajach socjalistycznych. Która z głównych stref/sektorów miasta jest zatem najbardziej, a która najmniej segregowana? Czy jest to centrum miasta, obszar o genezie presocjalistycznej, w którym obecnie działają procesy gentryfikacji i rewitalizacji? Czy może są to wielkie osiedla blokowe - wytwory epoki socjalistycznej, albo też strefa peryferyjna, która $\mathrm{z}$ uwagi na łatwo dostępne grunty stała się celem działań postsocjalistycznych deweloperów? Badania przekrojowe nad zjawiskiem segregacji społecznej prowadzone w różnych kontekstach instytucjonalnych i przestrzennych postsocjalistycznej Europy powinny udzielić odpowiedzi na powyższe pytania. 



\section{Rozdzial 4}

\section{Trzy stolice, trzy oblicza \\ Ewolucja zróżnicowań spoteczno-przestrzennych w Bukareszcie, Tallinie $i$ Warszawie}

Historia Bukaresztu, największego spośród analizowanych miast, sięga co najmniej XV wieku, jednak ranga tego miasta znacznie wzrosła po 1862 roku, kiedy stało się stolicą Rumunii. Pod koniec XIX wieku i na początku wieku XX Bukareszt, podobnie jak i inne wielkie miasta epoki, był miejscem silnych kontrastów społecznych i mieszkaniowych. Ludność uboga skupiona była w slumsach ówczesnej strefy peryferyjnej (w której budynki były często sklecone własnoręcznie z trzciny, gliny i innych materiałów), ale też w niskiej jakości kamienicach w strefie wewnętrznej (Turnock 1990). Ludność zamożna, burżuazja i inteligencja, zajmowała albo najlepsze kamienice w centrum, albo wille i luksusowe budynki wielorodzinne zlokalizowane wzdłuż zielonych bulwarów w północno-wschodnim sektorze miasta - np.: osiedla Kiseleff-Primăverii i Herăstrău oraz położone nad jeziorem osiedle Floreasca (rys. 5). Sytuacja ta utrzymała się do końca II wojny światowej, podczas której budynki mieszkalne nie zostały zbyt silnie zniszczone.

Pierwsze lata umacniania systemu socjalistycznego przyniosły nacjonalizację istniejących zasobów na cele mieszkaniowe oraz administracyjne (Chelcea 2012). Było to związane $z$ dobrze znanym $z$ innych państw socjalistycznych tego okresu dokwaterowywaniem nowych mieszkańców do dawnych właścicieli przestronnych mieszkań. Kolejnym wyzwaniem była pierwsza sztandarowa socjalistyczna przebudowa miasta. Za cel wybrano dzielnicę Grivița - dawny, bezkształtny robotniczy slums z okresu kapitalistycznego (Church 1979). Realizacja z przełomu lat 1950-1960 miała charakter modelowy - obok szerokiego bulwaru wzniesiono monumentalny budynek ówczesnego Ministerstwa Transportu i Telekomunikacji oraz dzielnicę prefabrykowanych budynków mieszkalnych i wielkie zakłady przemysłowe. Osiedla blokowe, zazwyczaj o niskim standardzie, towarzyszące pierwszej fali industrializacji socjalistycznej, powstały także w dzielnicach Rahova, Ferentari oraz Gara de Nord.

Proces forsownej industrializacji, który miał zmodernizować Rumunię, trwał nadal w latach 1960. i 1970. (Ronnås 1984), i zdecydowanie przerósł możliwości istniejących zasobów mieszkaniowych Bukaresztu. Nie sprostała mu pospieszna budowa nowych prefabrykowanych osiedli w pobliżu terenów przemysłowych - przede wszystkim kompleksów mieszkaniowych Obor (1966) i Mili- 
tari (1968) (rys. 5). Rzesza napływających do miasta robotników, podobnie jak i w wielu innych państwach socjalistycznych (Murray i Szelényi 1984), zaczęła nielegalnie lub półlegalnie zajmować strefę peryferyjną, wznosząc substandardowe budynki z drewna lub trzciny i gliny. Proces realizacji wielkich osiedli mieszkaniowych trwał nieprzerwanie w latach 1980. i 1990. Znakomitym tego przykładem są wielkie osiedla, takie jak Pantelimon, Balta Albă, Titan, czy też osiedle z końca lat 1970. - Drumul Taberei. Przyczyniło się to do sytuacji, w której prefabrykowany blok, często ponad dziesięciopiętrowy, stał się dominującą formą zabudowy w Bukareszcie. Jednak największa zmiana w przestrzeni miasta miała dopiero nadejść.

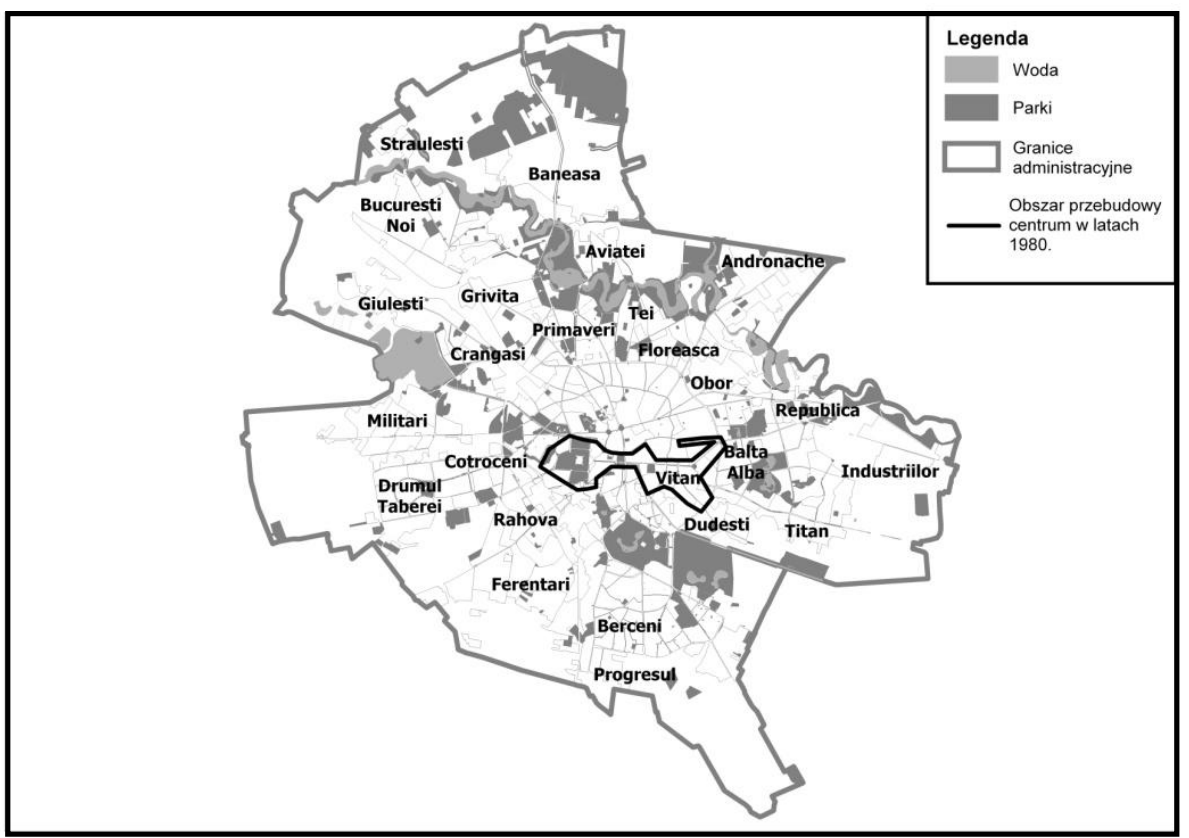

Rysunek 5: Główne obszary mieszkaniowe Bukaresztu Źródto: opracowanie własne

Współczesny Bukareszt nie byłby tym samym miastem bez Nicolae Ceaușescu i jego pomysłów, dotyczących przebudowy systemu socjalistycznego. Kulminacyjnym efektem procesu „systematyzacji” idei, która za pomocą przymusowej urbanizacji miała stworzyć nowe socjalistyczne społeczeństwo (Ronnås 
1984, Turnock 2007), była przebudowa centrum Bukaresztu. W efekcie jej działania w innych częściach Rumunii kilkanaście wsi i małych miasteczek przestało istnieć, jako nieefektywne, a ludność skupiona została w blokach towarzyszących szybko rosnącym miastom przemysłowym. W tym miejscu należy zaznaczyć, że obszary centralne innych wielkich miast socjalistycznych zostały w zasadzie przebudowane do połowy lat 1950., tak aby na stałe umieścić tam symbolikę nowego porządku (Bater 1980, Carter 1979, Smith 1996), zaś zakrojona na ogromną skalę przebudowa centrum Bukaresztu zaczęła się w końcu lat 1970. Chociaż zdaniem oficjalnej propagandy projekt ten był konieczny ze względu na zniszczenia wywołane trzęsieniem ziemi w 1977 roku, to jednak opinia publiczna przekonana była, że do szybkiej realizacji inwestycji przyczyniła się wizyta Nicolae Ceauşescu w Korei Północnej oraz jego zafascynowanie kultem jednostki w wydaniu stalinowskim i jego koreańską odmianą - ideą juche, wyrażoną m.in. przez układ przestrzenny Phenianu.

Skala, charakter i metody towarzyszące wdrażaniu projektu wydają się sugerować silny związek z inspiracją ze strony Korei Północnej. Sam projekt porównywany jest do planowanych lub zrealizowanych dzieł innych dyktatorów, jak np.: koncepcji przebudowy Berlina lansowanej przez Adolfa Hitlera, czy też zrealizowanej przez Józefa Stalina przebudowy Moskwy (Cavlacanti 1997). Dla przykładu warto dodać, że w momencie, gdy przebudowa centrum stolicy Rumunii wystartowała na dobre na początku lat 1980., systemy socjalistyczne w Polsce, czy na Węgrzech, zaczynały się chylić ku upadkowi, a w Związku Radzieckim niewiele później wprowadzona została pierestrojka.

Dla centrum Bukaresztu i jego mieszkańców, którzy zajmowali raczej heterogeniczny społecznie obszar o luźnej zabudowie, złożonej z domów jednorodzinnych i mniejszych kamienic, lata 1980. oznaczały dramatyczne zmiany. Zaplanowane wyburzenia w dużej mierze ułożyły się w pas o długości prawie czterech kilometrów i szerokości około trzystu metrów (rys. 5). Ponad 40000 ludzi zostało zmuszonych, często w bardzo krótkim czasie, do przesiedlenia (Turnock 1990). Miało to na celu stworzenie miejsca dla nowego wielkiego bulwaru o długości 3,5 kilometra i szerokości 92 metrów, wzdłuż którego, po obu stronach ciągną się wielopiętrowe budynki, a środkową oś, oprócz pasa zieleni, zdobi 17 fontann (Cavalcanti 1997). Kluczowym elementem inwestycji był Pałac Republiki, będący jednym z największych kubaturowo (jeśli nie największym) budynków świata. Luksusowe jak na tamte warunki mieszkania w budynkach zlokalizowanych wzdłuż nowo utworzonego bulwaru, miały być przeznaczone dla członków nomenklatury i wysokich urzędników tajnej policji (securitate) (Behr 1991). Wszystko to odbywało się w otoczeniu znacznego ubóstwa reszty społeczeństwa (O’Neill 2009). W kontekście zmian przestrzennych efekty wcielonych 
w życie planów najlepiej oddaje opinia D. Danta (1993, s. 170): „chyba żadne dzisiejsze miasto nie wyraża tak działania jednostki, jak Bukareszt ukazuje efekty działania Nicolae Ceauşescu".

Sam projekt, zwłaszcza monumentalny Pałac Republiki, został dokończony już po upadku systemu, we wczesnych latach 1990. Chociaż ustrój się zmienił, przy braku opozycji w stylu Solidarności w Polsce, władzę w dużej mierze przejęła dawna nomenklatura (Gabányi 2004). Do roku 1996, gdy władzę w kraju zdobyli liberałowie, tempo zmian było powolne, a zatrudnienie w wielkich zakładach przemysłowych w zasadzie utrzymane na typowo "socjalistycznym” poziomie. W tym miejscu należy podkreślić, że dzięki drakońskim planom oszczędnościowym Nicolae Ceauşescu, Rumunia w zasadzie nie miała długu międzynarodowego po zmianie systemu, w odróżnieniu od innych krajów postsocjalistycznych (Turnock 2007).

Jednak początkowa „oporna” transformacja pogrzebała dobre rokowania tego kraju. Pomimo jej powolnego tempa, w początku XXI wieku Rumunia cechowała się hiper-prywatną strukturą zasobów mieszkaniowych - ponad 90\% ogółu, podczas gdy średnia dla państw starej Unii Europejskiej to około 65\% (Ball 2006). Jednak dla Bukaresztu okres pierwszych dziesięciu lat od upadku systemu, chociaż wyróżniający się mniejszym tempem zmian niż procesy zachodzące w stolicach państw Europy Środkowo-Wschodniej (Tsenkova 2008), dzięki spolaryzowaniu wczesnego wzrostu gospodarczego na stolicy, oznaczał zmiany w jej przestrzeni. Można tu wskazywać na gentryfikację, komercjalizację, deindustrializację oraz rewitalizację, ale również na wykluczenie społeczne, które jest typowe dla innych miast postsocjalistycznych.

Kosmetyczne zmiany w przestrzeni miasta nabrały bardziej wyraźnego i trwałego charakteru w drugiej połowie lat 1990., a na dobre rozpoczęly się po 2003 roku (Nae i Turnock 2011). Zmiany społeczne odbywały się w warunkach masowej wówczas prywatyzacji zasobów mieszkaniowych oraz wolniejszej restytucji budynków i mieszkań. Podobnie, jak i w innych miastach postsocjalistycznych, również i w Bukareszcie uwagę deweloperów skupiły działki położone $\mathrm{w}$ centrum oraz jego sąsiedztwie. W omawianym mieście był to głównie jego północny sektor, stanowiący lokalizację luksusowych dzielnic willowych $\mathrm{z}$ początku XX wieku, jak również terenów rekreacyjnych i zieleni. Wolne przestrzenie wśród zabudowy o genezie socjalistycznej i presocjalistycznej zaczęły wypełniać nowe obiekty biurowe oraz atrakcyjne budynki mieszkaniowe o wysokim standardzie (ibid.). Przedwojenne wille oraz ekskluzywne kamienice odzyskane przez dawnych właścicieli także stanowiły obiekt zainteresowania lokalnego i zagranicznego kapitału. Szybkiemu rozwojowi przestrzennemu towarzyszyły również negatywne koszty społeczne, w tym wynikające poniekąd 
z socjalistycznej polityki demograficznej ${ }^{7}$ zjawisko bezdomności, zwłaszcza wśród młodzieży (O’Neill 2009), a także powstawanie enklaw biedy (Mionel i Neguţ 2011).

Tallin jest starym, sięgającym swą genezą XIII wieku, Hanzeatyckim miastem. Industrializacja i wzrost ludnościowy rozpoczęły się tu w 1860 roku pod rządami carskiej Rosji, które trwały do 1918 roku. Struktura społeczno-przestrzenna Tallina w zasadzie do odzyskania niepodległości wskazywała na istnienie burżuazyjnego centrum i terenów zajmowanych przez biedotę (zamieszkującą głównie drewniane domy), zlokalizowanych poza centralnym obszarem miasta (Ruoppila i Kährik 2003). Krótki okres niepodległości (1918-1940) nie doprowadził do większych zmian w tym zakresie, poza przeniesieniem się części wyższych i średnich kategorii społecznych do osiedli willowych, położonych w ówczesnej strefie podmiejskiej. Okres władzy radzieckiej, sprawowany z krótką przerwą od 1941 do 1991 roku, drastycznie zmienił oblicze miasta. W związku z szybką i szeroko zakrojoną industrializacją oraz napływem rzeszy imigrantów z innych części ZSRR, jego liczba ludności potroiła się i w 1989 roku wynosiła prawie 480000. Pamiętać należy, że Estonia była „priorytetową” i najbardziej „zachodnią" republiką byłego Związku Radzieckiego (Bater 1989).

W latach 1950. pierwsze socrealistyczne bloki oraz obiekty administracyjne wzniesiono $\mathrm{w}$ samym centrum Tallina lub $\mathrm{w}$ jego pobliżu, zwłaszcza $\mathrm{w}$ miejscach zniszczonych w wyniku działań II wojny światowej (Ruoppila i Kährik 2003). Szybsza budowa nowych mieszkań nastąpiła, podobnie jak i w innych miastach byłego Związku Radzieckiego, w latach 1960., wraz z upowszechnieniem prefabrykatów (French 1996). Począwszy od tego okresu, na wolnych terenach w strefie zewnętrznej powstawały wielkie osiedla mieszkaniowe: Mustamäe (inwestycję rozpoczęto w 1962 roku), Väikeõismäe (1974 rok) oraz licząca ponad 100000 mieszkańców Lasnamäe (1978 rok) (Ruoppila i Kährik 2003) (rys. 6). W celu przezwyciężenia znaczących braków mieszkaniowych, w strefie peryferyjnej miasta kontynuowano także budowę domów jednorodzinnych, zazwyczaj o nienajlepszej jakości. Jednak, zwłaszcza w latach 1980., do zabudowy tej dołączyły także budynki o wyższym standardzie, przeznaczone przede wszystkim dla ówczesnej elity. Wznoszono je głównie w dawnym mieścieogrodzie Nõmme, obecnie dzielnicy Tallina (rys. 6).

\footnotetext{
${ }^{7} \mathrm{~W}$ tym miejscu przypomnieć należy bardzo restrykcyjną i skrajnie pronatalistyczną politykę rządów reżimu Nicolae Ceauşescu, która zabraniała aborcji i antykoncepcji. Doprowadziło to do gwałtownej liczby urodzeń, a w warunkach ciągle pogarszających się warunków ekonomicznych, gdy plan dyktatora zakładał szybką spłatę długu zagranicznego, także do porzucania dzieci.
} 


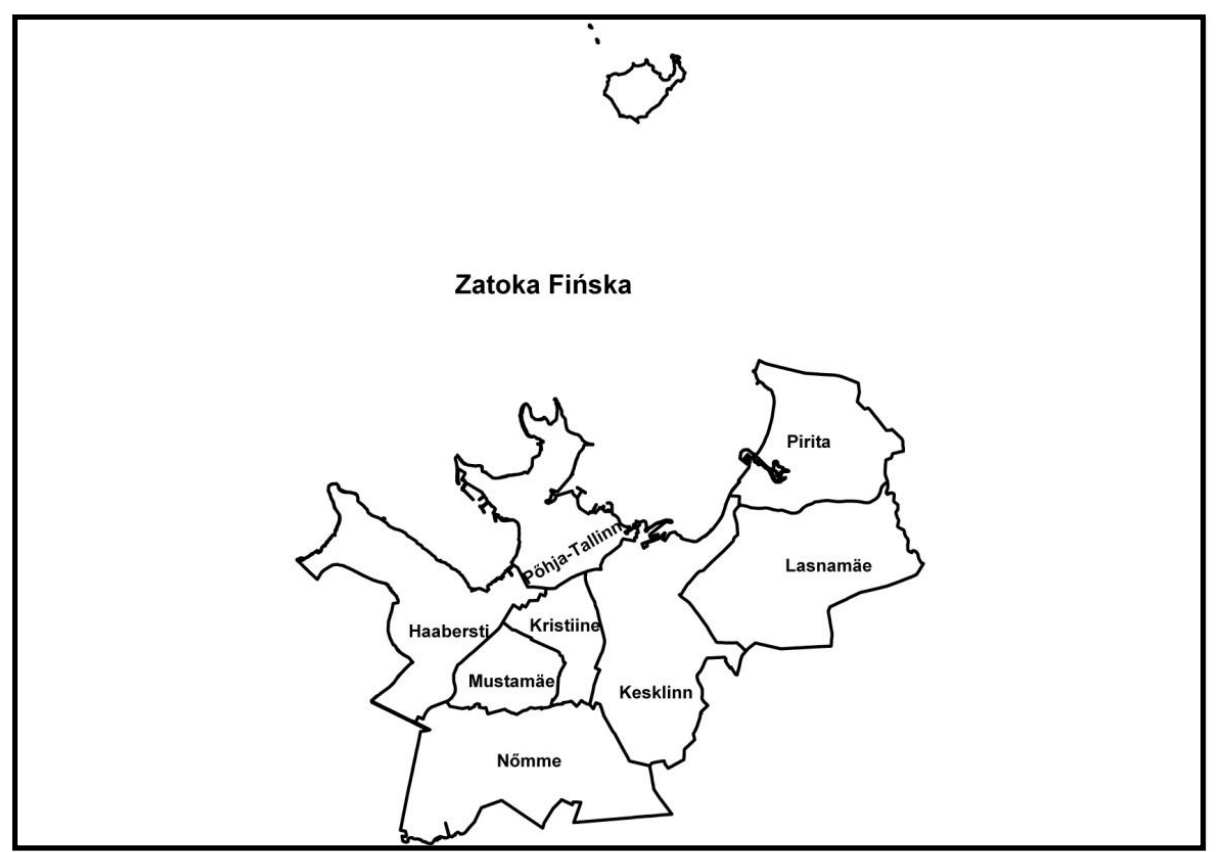

Rysunek 6: Dzielnice Tallina

Źródło: opracowanie własne

Poziom zróżnicowań społecznych, mierzony udziałem robotników i tak zwanych „białych kołnierzyków”, był wówczas niski (Raitviir 1990 - za Ruoppila i Kährik 2003). Wyższe kategorie społeczne zajmowały albo osiedla willowe o przedsocjalistycznej genezie, zlokalizowane w północno-wschodnim sektorze miasta, albo wybrane, atrakcyjne zasoby mieszkaniowe w centrum. $\mathrm{Z}$ kolei robotnicy zamieszkiwali zabudowę o niskim standardzie - drewniane domy położone na północnym półwyspie (Põhja-Tallinn), jak również budynki zlokalizowane w strefie wewnętrznej. Osiedla blokowe były w tym okresie heterogeniczne społecznie (mimo to występowały w nich czytelne podziały etniczne). Po zniesieniu kontroli meldunkowej w mieście mieszkańcy nowych osiedli (dobrym przykładem jest Lasnamäe ukończona w latach 1980.) przenieśli się tam z własnej woli (Kährik i Tammaru 2010), wszakże Tallin oferował najwyższe standardy życia w dawnym kraju rad (Bater 1989).

Zmiany zainicjowane odzyskaniem niepodległości w 1991 roku przyniosły radykalną liberalizację gospodarki i bardzo szybkie ograniczenie zakresu świad- 
czeń społecznych. Do końca lat 1990. w zasadzie przestały istnieć publiczne zasoby mieszkaniowe - udział własności prywatnej przekroczył 90\% ogółu (Ball 2006). Zmianie uległ charakter polityki mieszkaniowej, która, w odróżnieniu od krajów Europy Zachodniej (Musterd i Ostendorf 1998), według S. Ruoppili (2005) nie ma już nic wspólnego z redukcją nierówności społecznych - w myśl nowych zasad obywatel zdany jest $\mathrm{w}$ zasadzie wyłącznie na wolny rynek, a mieszkania socjalne przysługują jedynie w szczególnych przypadkach (byli więźniowie, osoby wyrzucane z mieszkań odzyskanych przez dawnych właścicieli, etc.).

Estonia stała się ikoną rozwoju gospodarczego opartego na neoliberalizmie ${ }^{8}$, czego kosztem był gwałtowny wzrost (jeden z najwyższych w regionie) nierówności społecznych mierzonych rozwarstwieniem w dochodach. W pierwszych trzech latach zmian (1991-1994), wskaźnik Giniego wzrósł z 23 do 37 - dla porównania, w tym samym okresie w Polsce ten sam indeks zwiększył swą wartość jedynie o 5 punktów (z 25 do 30) (Eurostat). Do początku XXI wieku poziom nierówności społecznych w Estonii wzrastał już nieznacznie, jednak w 2002 roku wciąż był najwyższy w regionie - nie licząc Rosji (ibid.). Co ciekawe, pomimo praktycznie całkowitej dominacji rynku w sferze mieszkalnictwa, czynsze w budynkach podlegających restytucji pozostały regulowane (Ruoppila 2005).

Wyniki badań nad zróżnicowaniem społeczno-przestrzennym Tallina w pierwszej dekadzie przemian nie wskazały istotnych zmian w rozmieszczeniu mieszkańców oraz towarzyszących im warunków zamieszkania (Ruoppila i Kährik 2003, Ruoppila 2005). Innymi słowy, pomimo radykalnego wzrostu nierówności społecznych, wzory przestrzenne w ich ogólnym zarysie nie zostały zmienione. Procesy wstępnej gentryfikacji i gwałtownej suburbanizacji (Letmaa i Tammaru 2007) utrwaliły i rozwinęly trendy zapoczątkowane w późnej fazie socjalizmu wzrostowi nadal ulegał status społeczny centrum oraz północno-wschodnich i północno-zachodnich suburbiów, zaś ogólnie niski status utrzymał północny półwysep (Ruoppila 2005). Zasadniczej zmianie społecznej i etnicznej nie podlegały także wielkie osiedla mieszkaniowe, które utrzymały ogólnie średni status (Kährik i Tammaru 2010).

W odróżnieniu od Bukaresztu i Tallina, struktura społeczno-przestrzenna Warszawy oraz trajektoria rozwoju gospodarczego i przestrzennego miasta sta-

${ }^{8}$ Znana w Estonii anegdota głosi, że pierwszy premier wybrany w wolnych wyborach Mart Laar - z wykształcenia doktor historii, przeczytał tylko jedną książkę z zakresu ekonomii i była to praca Miltona Friedmana, jednego z głównych apologetów neoliberalizmu. Mart Laar w dwa lata przeprowadził proces prywatyzacji, stał za wprowadzeniem podatku liniowego oraz reformy sektora bankowego. 
nowiły temat licznych opracowań naukowych (Smętkowski 2009, Węcławowicz 1978, 1988, 1992, 2008). Z tego powodu poniżej przedstawione zostaną jedynie najistotniejsze cechy zróżnicowań społeczno-przestrzennych największego miasta Polski. Podobnie jak w przypadku dwóch pozostałych stolic, do roku 1939 obraz podziałów społeczno-przestrzennych w Warszawie nawiązywał do modelu koncentrycznego. W ogólnym zarysie można stwierdzić, że obszarem zamieszkanym przez wyższe kategorie społeczne było śródmieście, a status społeczny mieszkańców malał wraz z odległością od centrum (Węcławowicz 1975). Obraz ten komplikowała urozmaicona struktura etniczna mieszkańców przedwojennej Warszawy, a przede wszystkim wyraźna koncentracja przestrzenna w strefie śródmiejskiej ludności żydowskiej o mieszanym statusie społecznym (Węcławowicz 1978). Jednak układ ten uległ prawie całkowitemu zatarciu w wyniku działań wojennych, gdy ponad $80 \%$ budynków uległo zniszczeniu. $Z$ dawnej tkanki miejskiej $\mathrm{w}$ relatywnie dobrym stanie pozostała jedynie prawobrzeżna część miasta (Praga).

Po 1945 roku dokonano odbudowy historycznego rdzenia, a znaczna część strefy śródmiejskiej zyskała zupełnie nowy charakter. W późnych latach 1940. i wczesnych latach 1950. nowe dzielnice mieszkaniowe wznoszono w stylu socrealistycznym (Marszałkowska Dzielnica Mieszkaniowa), a alokacja mieszkańców miała generalnie egalitarny charakter. W okresie tym, podobnie jak i w innych stolicach państw Bloku Wschodniego, powstało nowe, socjalistyczne centrum miasta - Plac Defilad wraz z Pałacem Kultury i Nauki. W latach 1960. dalsza rekonstrukcja strefy śródmiejskiej związana była z budową osiedli mieszkaniowych z prefabrykatów w miejscu wyburzonych kamienic. Analiza zróżnicowań społeczno-przestrzennych prowadzona w oparciu o wyniki spisu powszechnego z 1970 roku wskazywała na relatywnie niski poziom podziałów społecznych, zdecydowanie niższy niż przed 1939 rokiem (Węcławowicz 1978). Wyższe kategorie społeczne nadreprezentowane były w nowych osiedlach mieszkaniowych położonych w Śródmieściu oraz w przedwojennych budynkach o wysokim standardzie, które nie uległy zniszczeniu w latach 1939-1945 (Śródmieście, Żoliborz, część Mokotowa) (rys. 7). Niższe kategorie społeczne zajmowały przede wszystkim kamienice na Pradze oraz strefę peryferyjną (ibid.).

Okres socjalistyczny w zasadzie od samego początku oznaczał szybką industrializację - m.in. budowę huty oraz rozwój przemysłu maszynowego. Pamiętając o tym, że w ówczesnym systemie w zasadzie nie było miejsca dla niezależnie działających władz lokalnych, wszystkie najważniejsze funkcje gospodarki centralnie sterowanej (m.in. administracyjne czy kulturalne) zlokalizowane były $\mathrm{w}$ stolicy. Wiązało się to $\mathrm{z}$ szybkim wzrostem zatrudnienia w tych sektorach, co także wywarło silny wpływ na kształt struktury społecznej miasta. 
W tym miejscu zaznaczyć należy, że już we wczesnym okresie socjalistycznym Warszawa została objęta ścisłą kontrolą meldunkową, prowadzącą do selektywnego napływu nowych mieszkańców (Rykiel 1984).

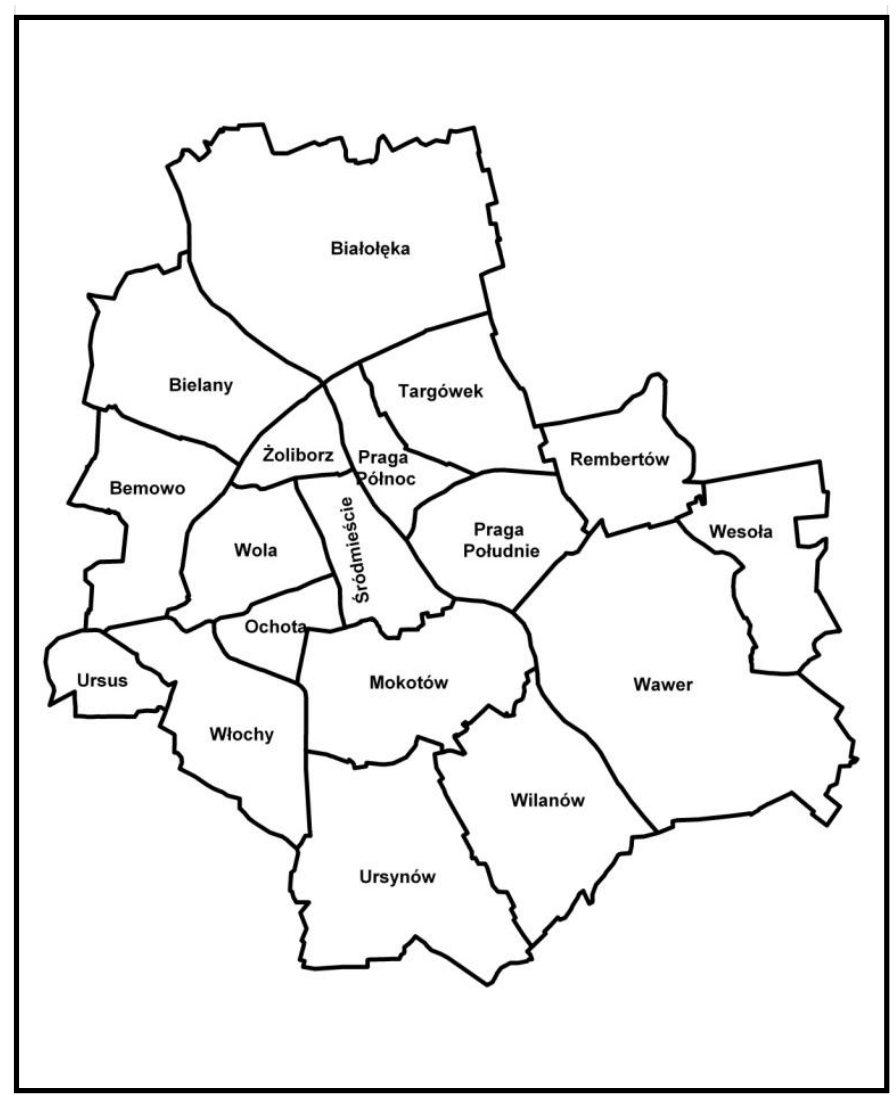

Rysunek 7: Dzielnice Warszawy

Źródło: opracowanie własne

Na dalszy rozwój zróżnicowań społeczno-przestrzennych w Warszawie największy wpływ wywarła budowa nowych dzielnic mieszkaniowych w formie sektorów przylegających do strefy śródmiejskiej oraz stopniowy zanik idei egalitaryzmu społecznego (Węcławowicz 1988). Innymi słowy, w warunkach permanentnych braków mieszkaniowych dostęp do nowych zasobów stawał się coraz 
bardziej wybiórczy, a promowane były zwłaszcza młode, lepiej wykształcone pary z dziećmi. Stąd też, począwszy od połowy lat 1970. wyższe kategorie społeczne koncentrowały się w nowej tkance mieszkaniowej (Ursynów). Z kolei kategorie niższe zajmowały przedwojenne kamienice w strefie śródmiejskiej, ale przede wszystkim peryferia (Węcławowicz 1992). Pomimo czytelnych podziałów w szerszej skali przestrzennej, miasto pozostało heterogeniczne społecznie, a obraz rozmieszczenia poszczególnych grup społecznych określić można było mianem mozaiki (ibid.). Sytuacja nie uległa większym zmianom do końca funkcjonowania systemu socjalistycznego, przy czym na dobre utrwalił się trend polegający na wzroście statusu społecznego wraz z oddalaniem się od centrum, zwłaszcza w odniesieniu do nowopowstałych osiedli blokowych (Węcławowicz 1992, Marcińczak i inni 2013a).

Okres posocjalistyczny wpłynął przede wszystkim na szybkie przemiany społeczne, przestrzenne i gospodarcze centrum miasta oraz szerzej pojętej strefy śródmiejskiej (Kowalski i Śleszyński 2006, Śleszyński 2004, Węcławowicz 1998). Wiązało się to z gwałtownym rozwojem sektora usług wyższego rzędu oraz wznoszeniem nowych budynków biurowych w ścisłym centrum Warszawy. Powrót mechanizmu renty gruntowej spowodował błyskawiczny wzrost cen nieruchomości, co z kolei miało wpływ na stopniowy odpływ z centralnych obszarów miasta wyższych kategorii społecznych (Stępniak i inni 2009) oraz kategorii najsłabszych, w tym ludności starszej (Węcławowicz 1998). Nowe projekty mieszkaniowe realizowane były zwłaszcza w strefie zewnętrznej (Stępniak 2012), a dostęp do nich uzależniony był od zasobności portfela. Obszary te stały się zatem miejscem koncentracji wyższych kategorii społecznych, w tym zwłaszcza wzrastającej rzeszy menadżerów i profesjonalistów, którzy zaczęli licznie napływać do miasta po 2002 roku (Marcińczak i inni 2012).

Pierwsza dekada po upadku systemu socjalistycznego nie przyniosła zasadniczych zmian w obrazie zróżnicowań społecznych, a jedynie utrwaliła trend cechujący późną fazę socjalistyczną (Marcińczak i inni 2013a). Innymi słowy, struktura społeczno-przestrzenna nadal pozostała mozaikowa (Smętkowski 2009), a status społeczny mieszkańców, w bardzo dużym uproszczeniu, wzrastał wraz z dystansem od centrum. Najbardziej elitarnymi osiedlami były: Natolin (położony na Ursynowie), Babice (mieszczące się na Bemowie) i Marymont oraz kompleks osiedli mieszkaniowych zlokalizowany na granicy Bielan i Żoliborza (Stępniak i inni 2009). Najniższy status społeczny cechował natomiast Bródno (osiedla $\mathrm{z}$ lat 1970. oraz zabudowa mieszana wchodząca w skład Targówka), Grochów (zlokalizowany na Pradze Południe) oraz osiedla blokowe na Służewie (część dzielnicy Mokotów (ibid.) (rys. 7). 
Z powyższego opisu ewolucji zróżnicowań społeczno-przestrzennych $\mathrm{w}$ trzech stolicach państw postsocjalistycznych wyłania się nieco odmienny obraz ogólnego rozmieszczenia poszczególnych kategorii społecznych w miastach północnej, środkowej i południowej części byłego Bloku Wschodniego. Jednak o skali, poziomie i dokładnych wzorach segregacji społecznej na początku XXI wieku decyduje nie tylko dziedzictwo fazy socjalistycznej i okresu przedsocjalistycznego, ale przede wszystkim tempo i charakter przemian demograficznych, społecznych i gospodarczych pierwszej dekady po 1990 roku. Rytm przemian w uniwersum miast postsocjalistycznych był zróżnicowany, ale stosunkowo szybko, po szoku wywołanym kryzysem ekonomicznym pierwszych lat transformacji, utrwaliły się pewne tendencje rozwojowe. Znacznie szybciej rozwijać się zaczęły przede wszystkim stolice państw Europy Środkowo-Wschodniej (Carter i Maik 1999, Węcławowicz 1998) i krajów bałtyckich (Tosics 2005). Z kolei późniejsze rozpoczęcie przemian, ale również ich bardzo żywiołowy charakter (Vöckler 2010), cechowały główne miasta Europy PołudniowoWschodniej (Bradshaw i Stenning 2004, Tsenkova 2008).

Różne oblicza przemian systemowych w pierwszej dekadzie transformacji w sposób syntetyczny ilustrują dane w tabeli 3. Biorąc pod uwagę liczbę mieszkańców, Bukareszt i Warszawa są średnio cztery razy większe od Tallina. Fakt ten jest istotny, gdyż duże miasta odznaczają się zazwyczaj wyższym poziomem segregacji niż miasta średnie czy małe (Krupka 2007). Tallin natomiast w zdecydowanie większym stopniu dominuje w strukturze osadniczej kraju.

Trzy omawiane miasta odróżnia także dynamika demograficzna po upadku poprzedniego systemu - jedynie Warszawa cechowała się nieznacznym wzrostem liczby ludności po 1991 roku. W Tallinie natomiast ubytek mieszkańców był najsilniejszy, a przyczynił się do niego szybki proces suburbanizacji (Leetmaa i inni 2009) oraz wyjazd za granicę części mniejszości rosyjskojęzycznej w początku lat 1990. Pomimo tego Tallin pozostał najbardziej zróżnicowanym etnicznie spośród analizowanych miast.

Chociaż liczba zmiennych użytych do ogólnej charakterystyki zasobów mieszkaniowych badanych ośrodków jest mocno ograniczona, $z$ dostępnych danych odczytać można zasadnicze różnice w tym zakresie pomiędzy Bukaresztem, Warszawą i Tallinem. Najlepsze warunki, biorąc pod uwagę wielkość mieszkań, panowały w stolicy Estonii. Jednak nie szło to w parze z poziomem wyposażenia $\mathrm{w}$ podstawowe instalacje techniczne i sanitarne. Pod względem dostępu do infrastruktury najlepiej prezentowały się zasoby mieszkaniowe zlokalizowane w Warszawie.

Z informacji zamieszczonych w tabeli 3 wyłania się także różne podejście do reformy struktury własnościowej zasobów mieszkaniowych. Pod tym względem 
można stwierdzić, że prywatyzacja mieszkań oraz ich restytucja na rzecz poprzednich właścicieli lub ich spadkobierców najszybciej i w sposób najbardziej intensywny przebiegała w Bukareszcie, a najwolniej w Warszawie. Innymi słowy, w stolicach Rumunii i Estonii rola komunalnych zasobów mieszkaniowych została gwałtownie ograniczona, a co za tym idzie, również i rola państwa w zakresie niwelowania za ich pomocą nierówności społecznych.

Pierwsza dekada przemian systemowych w różnym stopniu odcisnęła swoje piętno na strukturze gospodarczej trzech miast. Tempo zmian, polegających na wprowadzeniu w życie zasad wolnego rynku, a przede wszystkim na odejściu od zasady polityki pełnego zatrudnienia, dobrze oddają zmienne odnoszące się do stopy bezrobocia oraz jej wzrostu w analizowanym okresie. W Warszawie i Tallinie, stolicach państw, w których zaaplikowano szokową terapię w transformacji gospodarki socjalistycznej, poziom bezrobocia był średnio dwa razy większy niż w Bukareszcie. W stolicy Rumunii, gdzie starano się jak najdłużej utrzymać dawne osłony socjalne, poziom bezrobocia wzrósł nieznacznie. Przykład Tallina, gdzie bezrobocie wzrosło ponad dziewięciokrotnie, znakomicie ilustruje przejście od systemu sowieckiego do neoliberalnego kapitalizmu.

Analizując strukturę zatrudnienia w różnych sektorach gospodarki, trzy stolice w zasadzie są do siebie podobne. Jednak i w tym wymiarze funkcjonowania miast można wskazać pewne różnice. Otóż największe zatrudnienie w przemyśle odnotowano w Bukareszcie, gdzie industrializacja trwała do późnych lat 1980. Warszawa $\mathrm{z}$ kolei cechowała się największym udziałem zatrudnionych w sektorze związanym $\mathrm{z}$ finansami i bankowością, a więc $\mathrm{w}$ działalnościach będących ikonami neoliberalnej gospodarki. Kolejnym elementem, który wskazywał na najbardziej zaawansowaną liberalizację rynku pracy w stolicy Polski w porównaniu do dwóch pozostałych metropolii, był największy udział pracujących w niepełnym wymiarze godzin.

Biorąc pod uwagę obraz wyłaniający się $\mathrm{z}$ analizy zmiennych zamieszczonych $\mathrm{w}$ tabeli 3 i stosując gradację $\mathrm{w}$ stopniu zaawansowania i tempie transformacji społeczno-gospodarczej po 1990 roku (Hamilton i inni 2005), można zaliczyć Warszawę do miast liderów w procesie odbudowy gospodarki rynkowej i społeczeństwa demokratycznego, które coraz lepiej radzą sobie na arenie globalnej. Dobitnie świadczy o tym wzrost pozycji w rankingu miast globalnych/ światowych, najwyższy wśród analizowanych miast.

Estonia, podobnie jak i inne państwa bałtyckie, także należy do liderów transformacji, ale zmiany tam rozpoczęły się dopiero w początku lat 1990 . Chociaż tempo przemian społecznych i gospodarczych w Tallinie było bardzo gwałtowne, ze względu na niewielki rozmiar, rola tego miasta na arenie globalnej jest ograniczona. 
Tabela 3: Cechy struktury demograficznej, gospodarczej i mieszkaniowej Bukaresztu, Warszawy i Tallina na początku XXI wieku

\begin{tabular}{|l|c|c|c|}
\hline \multicolumn{1}{|c|}{ Cechy } & Bukareszt & Warszawa & Tallin \\
\hline Liczba ludności (2001) & 1936700 & 1689000 & 400000 \\
\hline Zmiana liczby ludności w latach 1991-2001 (1991=100\%) & 94 & 102 & 84 \\
\hline $\begin{array}{l}\text { Udział mieszkańców miasta w ogólnej liczbie mieszkańców } \\
\text { kraju (\%) }\end{array}$ & 9,00 & 4,00 & 30,00 \\
\hline Udział obcokrajowców w ogólnej liczbie mieszkańców (\%) & 0,60 & 7,00 & 29,00 \\
\hline Liczba mieszkań na 1000 mieszkańców & 402 & 423 & 432 \\
\hline Powierzchnia mieszkania na osobę (m²) & 17 & 22 & 22 \\
\hline $\begin{array}{l}\text { Udział mieszkań nie wyposażonych w podstawowe } \\
\text { instalacje (\%) }\end{array}$ & 9,08 & 5,00 & 18,94 \\
\hline Udział mieszkań prywatnych (\%) & 88,76 & 47,68 & 63,52 \\
\hline Stopa bezrobocia (\%) & 7,06 & 13,52 & 12,73 \\
\hline $\begin{array}{l}\text { Zmiana poziomu bezrobocia w latach 1991-2001 } \\
\text { (1991=100\%) }\end{array}$ & 114,00 & 330,00 & 950,00 \\
\hline Udział zatrudnionych w przemyśle i budownictwie (\%) & 31,36 & 23,23 & 28,66 \\
\hline Udział zatrudnionych w handlu, hotelach i restauracjach (\%) & 19,00 & 17,87 & 21,29 \\
\hline Udział zatrudnionych w finansach i biznesie (\%) & 12,59 & 22,75 & 12,21 \\
\hline $\begin{array}{l}\text { Udział zatrudnionych w administracji publicznej, opiece } \\
\text { zdrowotnej i edukacji (\%) }\end{array}$ & 27,34 & 26,77 & 24,33 \\
\hline Udział zatrudnionych w niepełnym wymiarze (\%) & 5,64 & 11,42 & 7,38 \\
\hline Pozycja w rankingu miast globalnych (2000)* & GAMMA+ & BETA+ & SUFFICIENCY \\
\hline Pozycja w rankingu miast globalnych (2004)* & ALPHA- & SUFFICIENCY \\
\hline
\end{tabular}

* ALPHA i ALPHA- - ważne ośrodki o znaczeniu międzynarodowym, łączące główne regiony gospodarcze z gospodarką światową; BETA - ośrodki o znaczeniu międzynarodowym, łączące regiony o umiarkowanym znaczeniu gospodarczym z gospodarką światową; GAMMA - ośrodki o znaczeniu międzynarodowym, łączące regiony o mniejszym znaczeniu gospodarczym z gospodarką światową; SUFFICIENCY - miasta posiadające funkcje metropolitalne rozwinięte w takim stopniu, aby nie być całkowicie zależnym od miast globalnych.

Źródło: Opracowanie własne na podstawie Urban Audit, GaWC 2000 oraz GaWC 2004 (http://www.lboro.ac.uk/gawc/world2000t.html) 
Stolica Rumunii najlepiej oddaje natomiast kontekst powolnych zmian w środowisku tak zwanej „opornej” (hesitant) transformacji (Turnock 2007), gdzie pomimo rozpoczęcia przemian już w 1989 roku, członkostwo w Unii Europejskiej przyznane zostało dopiero w 2007 roku. Pomimo tego, ze względu na wielkość i pozycję w regionie, Bukareszt jest liczącym się miastem w skali międzynarodowej. Pomimo odmiennej wielkości oraz roli w skali kontynentalnej i globalnej, ze względu na zakres pełnionych funkcji (por. Maik 2003, Parysek 2003) każdemu $\mathrm{z}$ trzech miast nadać można rangę metropolii o znaczeniu ponadnarodowym. Odwołując się do argumentów, głoszących że miasta silniej i głębiej osadzone w przestrzeni globalnych przepływów ludności i kapitału są bardziej nierówne i segregowane społecznie, można się spodziewać następujących poziomów segregacji społecznej w zbiorze trzech analizowanych miast: najwyższego w Warszawie, średniego w Bukareszcie i najniższego w Tallinie. 


\section{Rozdzial 5}

\section{Jak silnie podzielone? \\ Poziom segregacji spotecznej w Bukareszcie, Tallinie i Warszawie na początku XXI wieku}

Syntetyczne mierniki podziałów społeczno-przestrzennych, zwane najczęściej indeksami, dostarczają podstawowych i łatwych w interpretacji informacji o poziomie podziałów społecznych w przestrzeni miasta. Poniżej przedstawione zostaną interpretacje mierników opisujących stopień separacji i koncentracji, czyli dwóch głównych wymiarów zjawiska segregacji, poszczególnych grup społecznych w Bukareszcie, Warszawie i Tallinie. Opis ten uzupełniony zostanie o analizę poziomu segregacji $\mathrm{w}$ trzech podstawowych strefach/sektorach wymienionych stolic, a więc $\mathrm{w}$ strefie wewnętrznej, sektorach wielkich osiedli blokowych oraz w strefie peryferyjnej.

Przed przystąpieniem do szczegółowej charakterystyki skali segregacji społecznej w tych trzech wielkich miastach, jedna, kluczowa w przypadku studiów porównawczych nad zjawiskiem segregacji społecznej i/lub etnicznej kwestia, wymaga podkreślenia. Otóż, wartości indeksów segregacji zależą od wielkości jednostek przestrzennych, dla których agregowano dane. W tym miejscu warto zatem przypomnieć, że o ile jednostki przestrzenne wykorzystane $\mathrm{w}$ badaniach prowadzonych w Tallinie i Warszawie mają w zasadzie taką samą średnią liczbę ludności (około 500 osób aktywnych ekonomicznie), o tyle te użyte w przypadku Bukaresztu są około dziesięciokrotnie większe. Tym samym z dużą dozą prawdopodobieństwa można się spodziewać, że wyniki analiz otrzymane dla stolicy Rumunii będą zaniżone w porównaniu do rezultatów uzyskanych dla Warszawy i Tallina.

Indeks segregacji $(I S)$ oraz indeks braku podobieństwa $(I D)$ oddają poziom separacji przestrzennej poszczególnych grup społecznych. W interpretacji obu mierników zakłada się, że ich wartość wskazuje na udział procentowy członków danej grupy społecznej lub etnicznej/rasowej, który musiałby zmienić miejsce zamieszkania, aby ich rozkład w przestrzeni miasta był równomierny. Wyznaczone wartości pierwszej z miar (IS) prezentuje tabela 4. Indeks ten wskazuje na poziom separacji przestrzennej danej kategorii społecznej w stosunku do reszty ludności, a w tym przypadku konkretnie, w stosunku do pozostałych grup społeczno-zawodowych. Uzyskane wartości, nie przekraczające poziomu 0.30, oz- 
naczają niski lub średni ${ }^{9}$ poziom separacji przestrzennej w trzech omawianych miastach. Innymi słowy, wszystkie kategorie społeczne były relatywnie równomiernie rozlokowane w przestrzeni miejskiej.

Tabela 4: Indeksy segregacji dla grup społeczno-zawodowych w Bukareszcie, Warszawie i Tallinie na początku XXI wieku

\begin{tabular}{|l|c|c|c|}
\hline \multirow{2}{*}{ Grupy spoleczno-zawodowe } & \multicolumn{3}{c|}{ Indeks segregacji } \\
\cline { 2 - 4 } & Bukareszt & Warszawa & Tallin \\
\hline Parlamentarzyści, wyżsi urzędnicy i kierownicy & 0,21 & 0,17 & 0,17 \\
\hline Specjaliści & 0,24 & 0,19 & 0,15 \\
\hline Technicy & 0,09 & 0,08 & 0,08 \\
\hline Urzędnicy i średni personel biurowy & 0,08 & 0,1 & 0,08 \\
\hline Sprzedawcy i pracownicy sektora usług osobistych & 0,09 & 0,13 & 0,06 \\
\hline Robotnicy wykwalifikowani & 0,19 & 0,16 & 0,11 \\
\hline Operatorzy i monterzy maszyn & 0,18 & 0,17 & 0,13 \\
\hline Robotnicy niewykwalifikowani & 0,19 & 0,18 & 0,12 \\
\hline Bezrobotni & 0,17 & 0,1 & 0,15 \\
\hline
\end{tabular}

Źródlo: Opracowanie własne na podstawie wyników spisów powszechnych: Rumunia (2002), Polska (2002), Estonia (2000).

Jednak, pomimo ogólnie niskiego poziomu separacji, uwidaczniają się wyraźne różnice $\mathrm{w}$ równomierności rozmieszczenia analizowanych grup społecznych. W tym miejscu podkreślić należy, że otrzymane wyniki wpisują się w ogólny trend cechujący naturę podziałów społeczno-przestrzennych w wiel-

${ }^{9}$ Tutaj należy podkreślić, że poziom segregacji społecznej jest praktycznie zawsze niższy niż poziom segregacji etnicznej/rasowej, co w sposób klarowny dowiódł Sako Musterd (2005) dokonując studiów porównawczych nad miastami po obu stronach Atlantyku. Ze względu na powyższy fakt, w pracy tej przyjęto odmienne wartości progowe mierników segregacji niż te stosowane $\mathrm{w}$ pracach nad segregacją rasową (por. Massey i Denton 1993): wartości od 0 do 0.19 określono jako poziom niski, od 0.20 do 0.39 jako średni, a powyżej 40 jako wysoki. 
kim mieście, bez względu na dominujący system polityczno-gospodarczy (por. Duncan i Duncan 1955, Ladányi 1989, Morgan 1975, Musterd 2005). Profile separacji społecznej, jakie odczytać można z tabeli 4, wskazują na nieregularny kształt litery „U”. Innymi słowy wyższe kategorie społeczne są bardziej oddzielone przestrzennie od reszty społeczeństwa niż niższe grupy społeczne. Ponadto w Bukareszcie kategorie wyższe wydają się być bardziej separowane od reszty mieszkańców, niż ma to miejsce w Tallinie i Warszawie. Różnice te mogą być jednak znacznie większe, jednak nie sposób ich dociec ze względu na dostępną agregację przestrzenną danych spisowych z Rumunii.

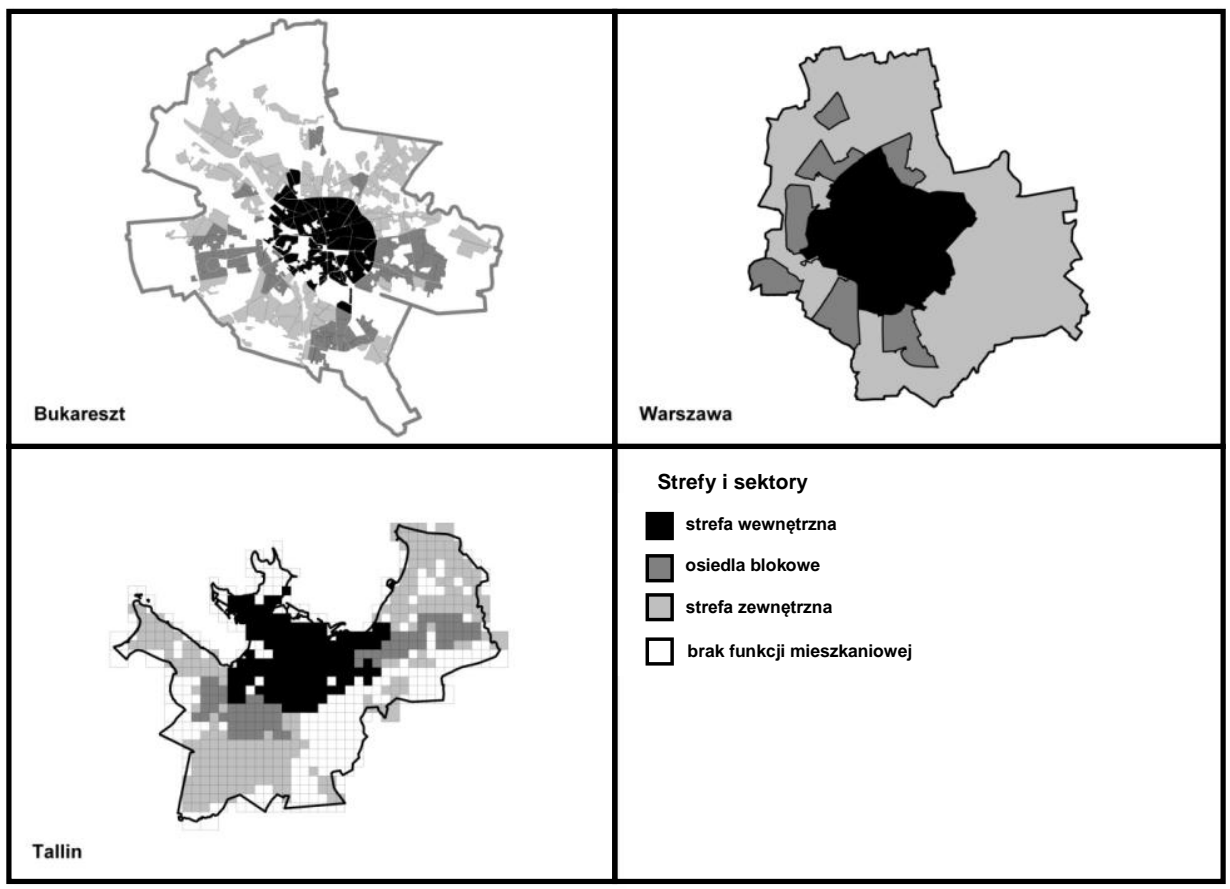

Rysunek 8: Podział Bukaresztu, Warszawy i Tallina i na główne strefy i sektory Źródlo: opracowanie własne

Więcej światła na naturę separacji społeczno-przestrzennej rzucają wyniki analizy prowadzonej w oparciu o podział trzech stolic na główne strefy/sektory (rys. 8). Zabieg ten pozwala na wskazanie, na ile poziom przestrzennych podziałów społecznych związany jest $\mathrm{z}$ charakterem głównych stref morfologicznych 
i funkcjonalnych miasta postsocjalistycznego, a zatem i z jego trajektorią rozwoju. Jeżeli obszary wielkich osiedli blokowych w zasadzie są do siebie podobne w każdym z wielkich miast byłego Bloku Wschodniego, to strefy wewnętrzna i zewnętrzna ośrodków w tej części Europy zachowały dziedzictwo fazy przedsocjalistycznej. Przyglądając się bliżej trzem badanym stolicom można powiedzieć, że najbardziej odróżnia je stopień przekształceń przestrzennych i związany z nim charakter przebudowy strefy śródmiejskiej w epoce socjalizmu - od prawie nietkniętej w Tallinie, przez poważnie zmienione centrum Bukaresztu, do w zasadzie stworzonego od nowa po 1945 roku śródmieścia Warszawy. Wartości indeksów segregacji dla poszczególnych kategorii spo-łecznych w wydzielonych strefach Bukaresztu, Tallina i Warszawy prezentuje tabela 5.

Tabela 5: Indeksy segregacji dla grup społeczno-zawodowych w głównych strefach i sektorach Bukaresztu, Warszawy i Tallina na początku XXI wieku.

\begin{tabular}{|l|c|c|c|c|c|c|c|c|c|}
\hline \multirow{2}{*}{\multicolumn{1}{|c|}{ Grupy społeczno-zawodowe }} & \multicolumn{3}{|c|}{ Bukareszt } & \multicolumn{3}{c|}{ Warszawa } & \multicolumn{4}{c|}{ Tallin } \\
\cline { 2 - 10 } & SW & BL & SZ & SW & BL & SZ & SW & BL & SZ \\
\hline $\begin{array}{l}\text { Parlamentarzyści, wyżsi urzędnicy } \\
\text { i kierownicy }\end{array}$ & 0,09 & 0,15 & 0,24 & 0,16 & 0,16 & 0,18 & 0,2 & 0,1 & 0,17 \\
\hline Specjaliści & 0,11 & 0,18 & 0,26 & 0,18 & 0,2 & 0,21 & 0,19 & 0,11 & 0,15 \\
\hline Technicy & 0,07 & 0,06 & 0,12 & 0,08 & 0,08 & 0,12 & 0,11 & 0,06 & 0,08 \\
\hline Urzędnicy i średni personel biurowy & 0,06 & 0,06 & 0,08 & 0,09 & 0,09 & 0,11 & 0,09 & 0,06 & 0,08 \\
\hline $\begin{array}{l}\text { Sprzedawcy i pracownicy sektora } \\
\text { usług osobistych }\end{array}$ & 0,07 & 0,07 & 0,09 & 0,12 & 0,14 & 0,14 & 0,07 & 0,05 & 0,06 \\
\hline Robotnicy wykwalifikowani & 0,14 & 0,14 & 0,18 & 0,14 & 0,17 & 0,19 & 0,15 & 0,07 & 0,11 \\
\hline Operatorzy i monterzy maszyn & 0,15 & 0,15 & 0,19 & 0,16 & 0,18 & 0,2 & 0,15 & 0,09 & 0,13 \\
\hline Robotnicy niewykwalifikowani & 0,16 & 0,11 & 0,21 & 0,18 & 0,18 & 0,24 & 0,14 & 0,07 & 0,12 \\
\hline Bezrobotni & 0,22 & 0,15 & 0,17 & 0,14 & 0,13 & 0,16 & 0,17 & 0,11 & 0,14 \\
\hline
\end{tabular}

$\mathrm{SW}$ - strefa wewnętrzna; BL - wielkie osiedla mieszkaniowe; SZ - strefa wewnętrzna. Źródto: Opracowanie własne na podstawie wyników spisów powszechnych: Rumunia (2002), Polska (2002), Estonia (2000). 
Już pobieżna inspekcja zawartości powyższej tabeli wskazuje na fakt, że poziom separacji społecznej nie jest taki sam w różnych strefach miasta postsocjalistycznego. Chociaż różnice w skali podziałów społeczno-przestrzennych pomiędzy wyodrębnionymi obszarami są czytelne w każdym z badanych miast, nie można niestety mówić o uniwersalnym trendzie opisującym relacje pomiędzy poziomem separacji społeczno-przestrzennej a odległością od centrum w mieście postsocjalistycznym. Chociaż przykład Warszawy skłania ku postawieniu tezy o wzroście poziomu separacji społecznej wraz z tym dystansem, a argument ten znajduje również potwierdzenie w postaci wyników dla wyższych kategorii społecznych w Bukareszcie, to jednak rezultaty z Tallina nakazują zachować pewną rezerwę. W stolicy Estonii najbardziej segregowana społecznie była strefa śródmiejska, która pomimo sowietyzacji po 1945 roku w znacznej mierze zachowała swój historyczny charakter. Ciekawym jest także fakt, że w Tallinie najniższy poziom podziałów społeczno-przestrzennych zanotowano w dzielnicach blokowych, co biorąc pod uwagę dziedzictwo socjalizmu oraz niewielką mobilność mieszkaniową w pierwszej dekadzie transformacji można thumaczyć za J. H. Baterem (1989) w taki sposób, że na wielkich osiedlach blokowych to powierzchnia mieszkania, a nie jego lokalizacja była głównym celem ówczesnej klasy średniej. Warto także wspomnieć, że tylko profil poziomu podziałów społeczno-przestrzennych $\mathrm{z}$ Tallina wpisywał się w prezentowany już w pracy modelowy obraz zmienności przestrzennej tego zjawiska.

W Warszawie, ale także w Bukareszcie, najbardziej heterogeniczne społecznie są strefy śródmiejskie. Jednak stolice Polski i Rumunii znacznie bardziej niż Tallin zbliżone były do ideału ,prawdziwego" miasta socjalistycznego, bowiem znaczna część tkanki miejskiej, nawet w obszarach centralnych, powstała po wprowadzeniu socjalizmu (por. French i Hamilton 1979). Oznaczało to, oprócz przebudowy mającej na celu podkreślenie ideologii, zakrojony na szeroką skalę rozwój osiedli blokowych w dawnym centrum, w zasadzie od początku trwania systemu (Smith 1996). Rezultaty wyników badań z Warszawy, a przede wszystkim stwierdzony wyższy poziom separacji społecznej na osiedlach blokowych niż w śródmieściu, pomimo upływu prawie dwóch dekad potwierdza przekonanie G. Węcławowicza (1988) o upadku egalitaryzmu w polityce mieszkaniowej późnego socjalizmu w Polsce. Obszary, które zakwalifikowano do kategorii „osiedla blokowe" w Warszawie, zabudowane były głównie obiektami powstającymi od lat 1970. (Stępniak 2012)

Jak zasygnalizowano to już w niniejszej pracy, strefa śródmiejska Bukaresztu poddana została radykalnej przebudowie w latach 1980. Pamiętając o tym, że wprowadzenie nowych wielokondygnacyjnych bloków, przeznaczonych dla socjalistycznej elity, ograniczało się do stworzenia 'fasad' wzdłuż nowych alei 
i bulwarów, niski poziom podziałów społeczno-przestrzennych można do pewnego stopnia tłumaczyć charakterem dostępnych materiałów źródłowych. Otóż jednostki podziału przestrzennego Bukaresztu, dla których udało się pozyskać dane ilościowe, były ze względu na swą wielkość bardziej zróżnicowane morfologicznie i społecznie niż w przypadku dwóch pozostałych stolic. Ograniczenie nowej tkanki mieszkaniowej do relatywnie wąskiego pasa wzdłuż głównych śródmiejskich arterii, przy pozostawieniu dużego udziału zabudowy o relatywnie niskim statusie społecznym, skutkować musiało wzrostem różnorodności społecznej w skali przestrzennej wykorzystanych w badaniach jednostek.

We wszystkich miastach, a w Warszawie i Bukareszcie w największym zakresie, najsilniej podzielone społecznie były strefy zewnętrzne. Na tych obszarach, ze względu na odziedziczony po epoce socjalizmu relatywnie niski poziom statusu społecznego (z wyjątkiem wysp osiedli willowych z epoki przedsocjalistycznej, które przeważnie zachowały wysoki status), doszło do dramatycznej transformacji struktur społeczno-przestrzennych. Relatywnie luźno zagospodarowane tereny mieszkaniowe o generalnie niskim standardzie, nierzadko o charakterze wiejskim, bardzo szybko po upadku poprzedniego systemu dopełnione zostały kompleksami mieszkaniowymi wznoszonymi przez deweloperów. Nowe budownictwo mieszkaniowe doprowadziło do powstania enklaw nowej klasy średniej i wyższej w budynkach, często strzeżonych (Gądecki 2009), które zlokalizowano na łatwo dostępnych i atrakcyjnych terenach w strefie zewnętrznej (Marcińczak 2012). Niższe kategorie społeczne pozostały w dawnej tkance mieszkaniowej (Marcińczak i inni 2013a, b).

Wgląd w związek pomiędzy dystansem społecznym i dystansem przestrzennym zapewniają wartości indeksu braku podobieństwa (ID) (Duncan i Duncan 1955). Z uwagi na fakt, że rezultaty $I D$ powiązane są z wartościami indeksu segregacji $(I S)$ - niższe wartości $I S$ oznaczają także niższe wartości $I D$ - ich przegląd ograniczony zostanie do opisu poziomu podziałów pomiędzy poszczególnymi kategoriami społeczno-zawodowymi w skali przestrzennej całego miasta (tab. 6-8).

Analiza rezultatów obliczeń poziomu separacji społeczno-przestrzennej pomiędzy wszystkimi parami kategorii społeczno-zawodowych w trzech stolicach wskazuje na dwie wyraźne prawidłowości. Jako pierwszą z nich można wskazać wyraźną gradację ośrodków w skali podziałów społeczno-przestrzennych, przy czym najbardziej podzielonym miastem jest Bukareszt, a najmniej Tallin. Poziom podziałów społeczno-przestrzennych pomiędzy skrajnymi kategoriami społeczno-zawodowymi w Bukareszcie i Warszawie określić można mianem średniego, natomiast w Tallinie $\mathrm{z}$ reguły skala podziałów pozostaje niska. 


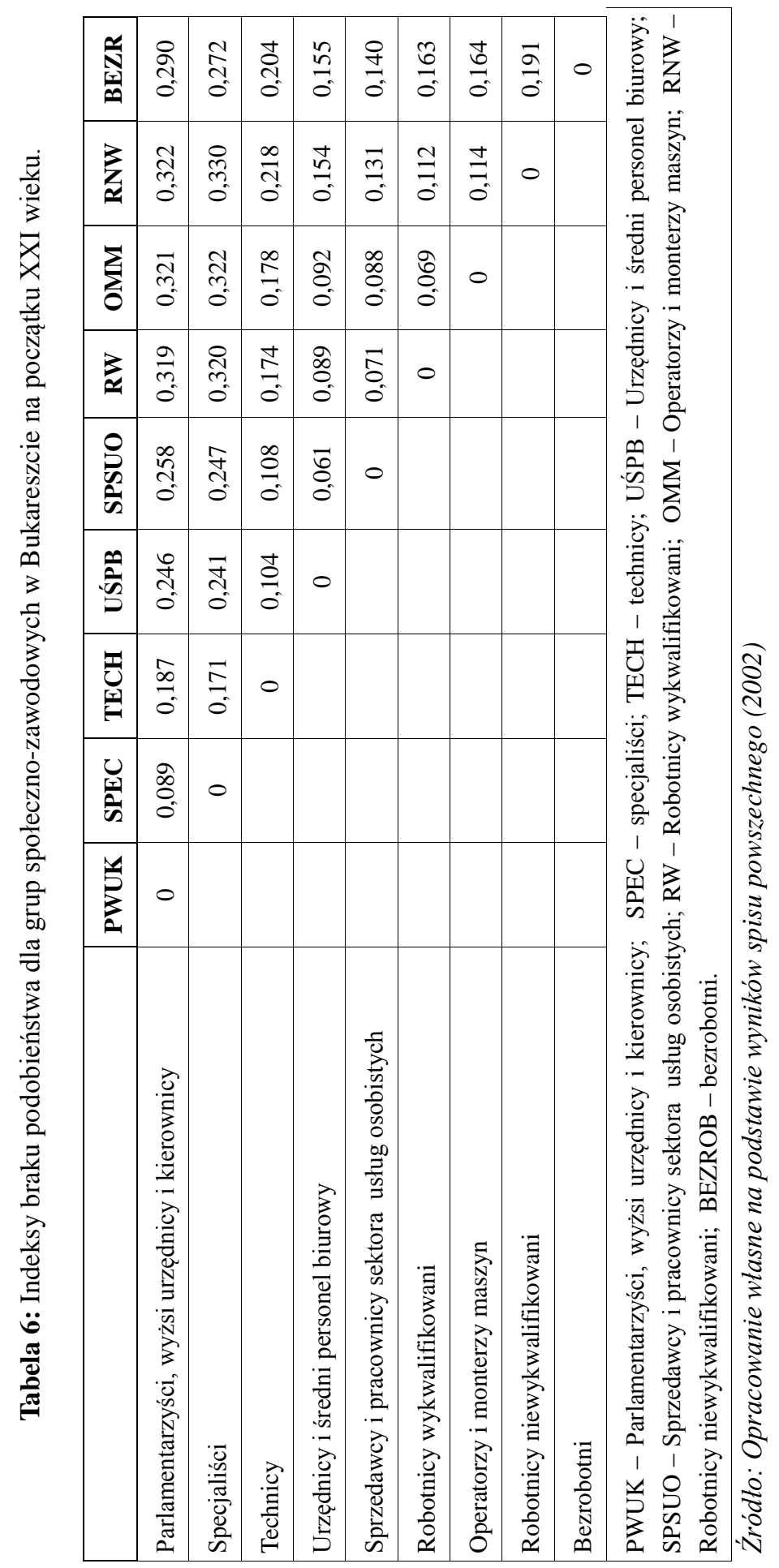




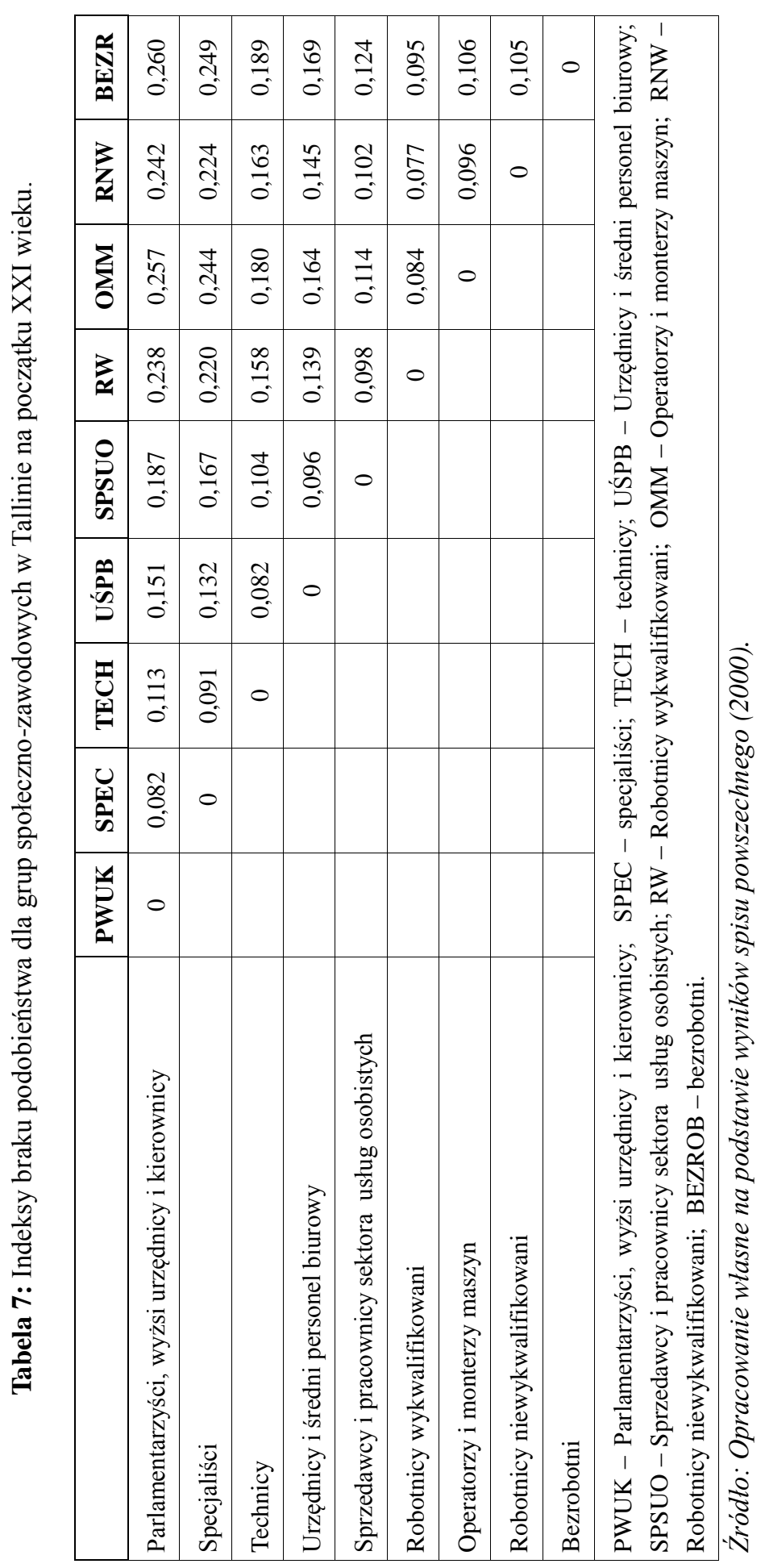




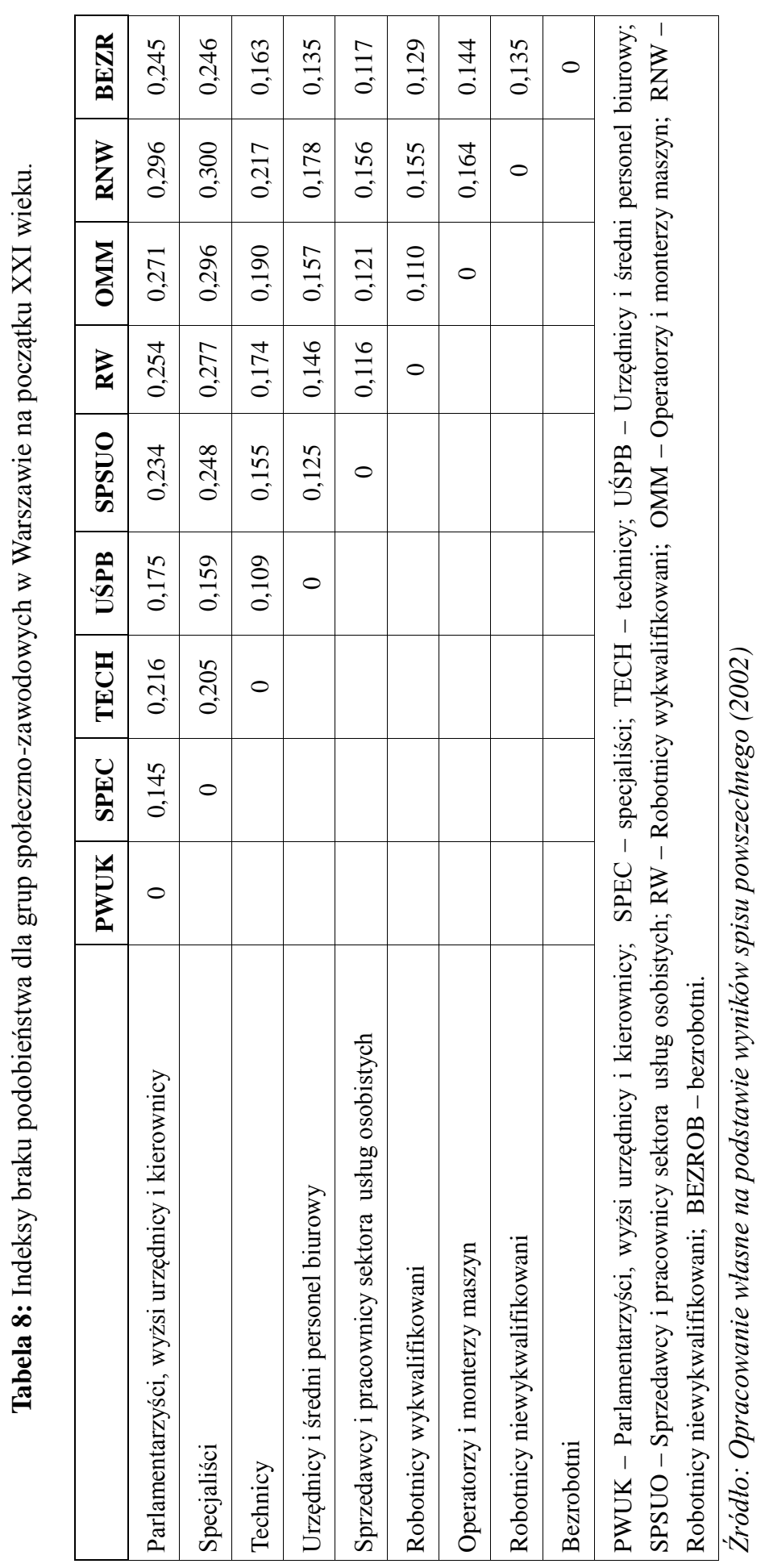


Drugi z trendów wydaje się być bardziej interesujący, zwłaszcza z perspektywy osadzenia wyników badań pochodzących z miasta postsocjalistycznego w kontekście zależności znanych z miast kapitalistycznych (Duncan i Duncan 1955, Morgan 1975). Otóż główna linia podziałów społeczno-przestrzennych w Bukareszcie, Warszawie i Tallinie, podobnie jak i w typowym mieście kapitalistycznym (Scott 1988), oddziela najwyższe kategorie społeczne (kadrę zarządzającą oraz profesjonalistów) od mieszkańców zatrudnionych na stanowiskach robotniczych. Średnie kategorie społeczne są w zasadzie najbardziej równomiernie rozmieszczone w przestrzeni, jednak częściej zamieszkują w sąsiedztwie ludności robotniczej niż wyższych kategorii społecznych (tab. 6-8). Innymi słowy w mieście postsocjalistycznym, bez względu na poziom separacji społecznoprzestrzennej, dystans społeczny rośnie wraz z dystansem przestrzennym.

Porównując poziom segregacji społecznej $\mathrm{w}$ trzech omawianych miastach z wynikami badań pochodzącymi z miast Ameryki Północnej oraz Europy Zachodniej (Musterd 2005) można stwierdzić, że rezultaty zanotowane w Tallinie lokowały to miasto blisko skali podziałów znanych $\mathrm{z}$ miast skandynawskich. Z kolei wyniki pochodzące z Bukaresztu, ale też i Warszawy, stawiają je w okolicach Europejskiej średniej, w pobliżu miast włoskich (ibid.). Tym samym poziom podziałów społecznych w ośrodkach miejskich $\mathrm{z}$ różnych regionów byłego Bloku Wschodniego był znacznie niższy niż w znanych z wysokich nierówności społecznych miastach Stanów Zjednoczonych, gdzie wypracowane zostały terminy polaryzacja i dualizacja społeczna (społeczno-przestrzenna).

Indeks izolacji (II) stanowi syntetyczną miarę drugiego z głównych wymiarów zjawiska segregacji społeczno-przestrzennej, którym jest koncentracja. Ze względu na relatywny charakter rezultatów dostarczanych przez II, zależą one od liczebności i udziału danej grupy społecznej lub etnicznej w ogóle populacji. Większe grupy społeczne, z uwagi na znaczny udział w ogóle ludności, zawsze dostarczą większe wartości II niż grupy mniej liczebne i o mniejszym udziale (Sin 2003). Stąd też w tabeli 9, oprócz oceny absolutnego poziomu izolacji, jakiej dostarczają rezultaty II, podane zostaną także wyniki modyfikowanego indeksu izolacji (MII), który zapewnia informację o relatywnym poziomie izolacji, niezależnym od wielkości badanej kategorii społecznej. Innymi słowy miernik ten pozwala uchwycić, na ile izolacja przestrzenna zależy od innych czynników (wybór jednostkowy, polityka mieszkaniowa, etc.) niż tylko liczebność grupy społecznej. Oba indeksy przyjmują wartości od 0 do 100 i interpretowane są jako prawdopodobieństwo zamieszkiwania w tym samym sąsiedztwie przez członków tej samej grupy społecznej. 


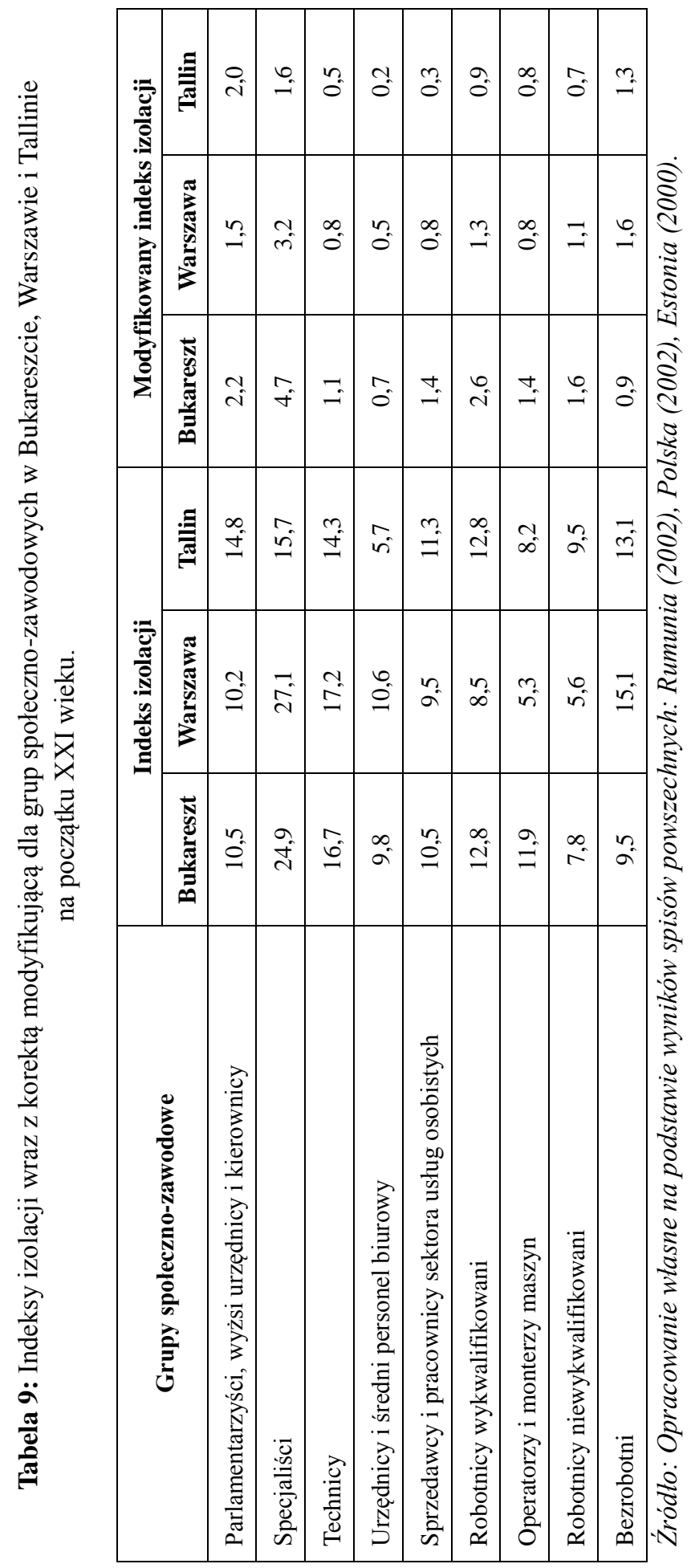


Indeks izolacji oraz jego modyfikowana wersja w dużej mierze powielają prawidłowości wskazane za pomocą analizy poziomu separacji. Otóż najbardziej segregowaną spośród trzech stolic, biorąc pod uwagę poziom izolacji (koncentracji), jest Bukareszt, a najsłabiej Tallin. Poziom izolacji mieszkaniowej dla wszystkich kategorii społeczno-zawodowych z wyjątkiem „specjalistów” określić należy jako niski. We wszystkich wielkich miastach znacznie silniej izolowane przestrzennie były wyższe kategorie społeczne. Dotyczyło to absolutnego i relatywnego poziomu izolacji. Odnosząc się do prezentowanych powyżej rezultatów analizy separacji społeczno-przestrzennej, można powiedzieć, że w mieście postsocjalistycznym profil skali podziałów społecznych, przypomninający nieregularną literę „U”, odnosi się także do drugiego z podstawowych wymiarów segregacji, czyli poziomu koncentracji przestrzennej poszczególnych grup społecznych.

Analizę poziomu koncentracji grup społecznych w trzech głównych obszarach (strefach) miasta postsocjalistycznego ograniczono do zastosowania indeksu izolacji w wersji niemodyfikowanej. Decyzja ta podyktowana została kolejnymi etapami badań nad koncentracją, które rozwijają miary absolutnego poziomu izolacji. Wartości indeksów dla kategorii społecznych w poszczególnych strefach Bukaresztu, Warszawy i Tallina prezentuje tabela 10. W odróżnieniu od trendów ujawnionych przez miary separacji, wartości indeksów izolacji przestrzennej poszczególnych grup społecznych nie wskazują tak spójnych wzorów. Innymi słowy, o ile poziom separacji społeczno-przestrzennej rósł wraz z dystansem od centrum w Bukareszcie i Warszawie, o tyle wzory koncentracji nie wpisywały się w ten schemat.

Pomimo braku wyraźnych trendów w rozkładzie poziomu koncentracji w badanych stolicach, z tabeli 11 odczytać można pewne regularności dotyczące wybranych kategorii społeczno-zawodowych. Bez względu na poziom separacji społeczno-przestrzennej w każdej ze stolic strefa wewnętrzna stanowiła obszar, w którym najsilniej skoncentrowane (izolowane) były wyższe grupy społeczne. Inną cechą szczególną zmienności poziomu izolacji lepiej sytuowanych grup społecznych w trzech głównych strefach wszystkich stolic, był jego spadek na terenie jednostek zaliczonych do „osiedli blokowych”, po którym następował wzrost koncentracji w strefie zewnętrznej.

Odmienne prawidłowości cechowały rozkład stopnia izolacji przestrzennej niższych kategorii społecznych. Mianowicie ludność zatrudniona na stanowiskach robotniczych jest najsilniej skoncentrowana w strefie zewnętrznej. 


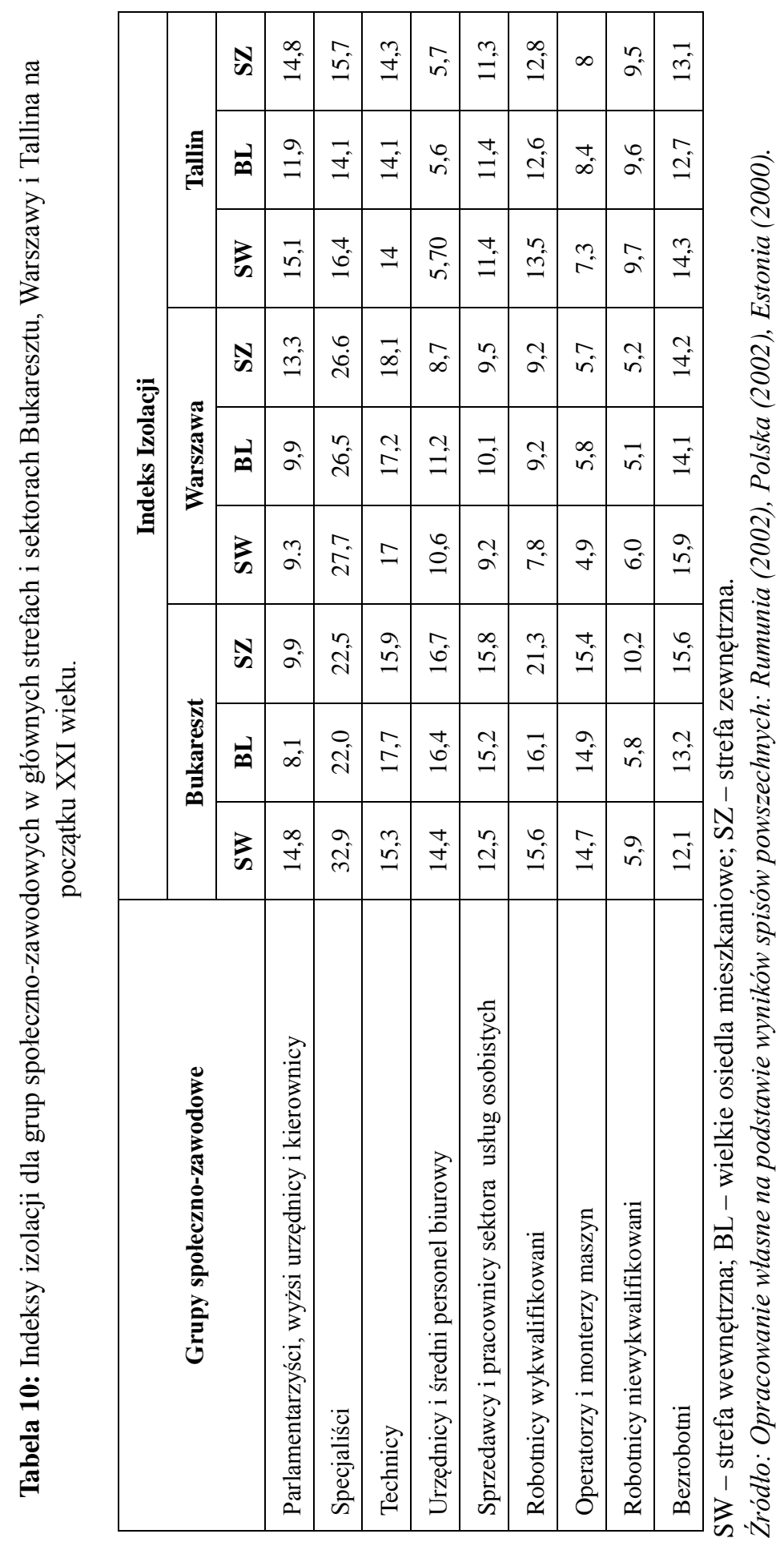


Trend ten jest najbardziej wyraźny w Bukareszcie, o czym decydować może specyfika miasta Europy Południowo-Wschodniej, gdzie strefa peryferyjna w okresie socjalistycznym skupiała najniższe kategorie społeczne, w często nielegalnym budownictwie substandardowym, a brak uregulowanego statusu prawnego tkanki mieszkaniowej nie pozwolił na swobodny obrót nieruchomościami w pierwszej dekadzie transformacji. Wzrost izolacji przestrzennej niższych kategorii społecznych wraz z odległością od centrum jest znacznie mniej czytelny w Warszawie. W Tallinie natomiast ludność robotnicza najmocniej izolowana jest w strefie wewnętrznej. Pamiętając o tym, że śródmieście stolicy Estonii odznaczało się także najwyższym poziomem izolacji kategorii wyższych, zakładać można istnienie wyraźnej fragmentacji społeczno-przestrzennej tego obszaru.

Tabela 11: Udział trzech kategorii społecznych w ogóle ludności aktywnej ekonomicznie w głównych strefach i sektorach Bukaresztu, Warszawy i Tallina na początku XXI wieku.

\begin{tabular}{|l|c|c|c|c|c|c|c|c|c|}
\hline \multirow{2}{*}{$\begin{array}{c}\text { Kategorie } \\
\text { społeczne }\end{array}$} & \multicolumn{6}{|c|}{ Udział w ogóle ludność aktywnej ekonomicznie } \\
\cline { 2 - 11 } & \multicolumn{4}{|c|}{ Bukareszt } & \multicolumn{3}{c|}{ Warszawa } & \multicolumn{4}{c|}{ Tallin } \\
\cline { 2 - 11 } & SW & BL & SZ & SW & BL & SZ & SW & BL & SZ \\
\hline Wyższa & 44,70 & 26,31 & 23,73 & 32,93 & 31,51 & 34,26 & 26,89 & 24,51 & 35,98 \\
\hline Średnia & 30,23 & 37,07 & 34,43 & 35,06 & 36,66 & 32,72 & 29,84 & 30,59 & 30,17 \\
\hline Niższa & 24,86 & 35,45 & 41,54 & 30,45 & 29,97 & 28,85 & 40,01 & 41,69 & 30,65 \\
\hline
\end{tabular}

$\mathrm{SW}$ - strefa wewnętrzna; BL - wielkie osiedla mieszkaniowe; SZ - strefa zewnętrzna. Źódto: Opracowanie własne na podstawie wyników spisów powszechnych: Rumunia (2002), Polska (2002), Estonia (2000).

Rozwinięcie klasycznego indeksu izolacji stanowią profile koncentracji, które są łatwą w interpretacji metodą graficzną, zapewniającą dokładniejszy wgląd we wzory koncentracji mieszkaniowej poszczególnych kategorii społecznych. Ze względu na zwiększenie czytelności profili koncentracji oryginalne pozycje społeczno-zawodowe zagregowano do trzech zasadniczych kategorii, które dobrze oddają ogólne linie podziałów społecznych po upadku socjalizmu, a zwłaszcza podział na „zwycięzców” i „przegranych” w toku transformacji ustrojowej (por. Węcławowicz 2004). Na zasadność zaproponowanej klasyfikacji grup społeczno-zawodowych wskazują też prezentowane w tej pracy wyniki analizy poziomu separacji społecznej. Wyższa kategoria społeczna obejmuje zatem par- 
lamentarzystów, kierowników, wyższych urzędników oraz profesjonalistów. W skład średniej kategorii społecznej wchodzą technicy, urzędnicy, średni personel oraz pracownicy sektora usług osobistych i sprzedawcy. Do kategorii niższej zaliczeni zostali robotnicy wykwalifikowani i niewykwalifikowani, ale też operatorzy i monterzy maszyn oraz bezrobotni. Wzory koncentracji przestrzennej trzech ogólnych kategorii społecznych w głównych strefach miasta postsocjalistycznego w Bukareszcie, Warszawie i Tallinie przedstawia rysunek 9.

Ogólne różnice w statusie społecznym, pomocne w interpretacji profili koncentracji, prezentuje rozkład udziału poszczególnych kategorii społecznych w trzech zasadniczych strefach/sektorach miasta postsocjalistycznego. Analiza zawartości tabeli 11 potwierdza różnice zasygnalizowane przez wyniki indeksu izolacji, jednak, jak już zostało to zasygnalizowane poprzez prezentację wartości indeksów, wzory koncentracji mieszkaniowej poszczególnych grup społecznych w trzech stolicach wymykają się prostym uogólnieniom. Innymi słowy nie ma jednego trendu, który opisywałby zmienność wzorów koncentracji społecznej w wielkim mieście postsocjalistycznym. Jednak profile koncentracji sporządzone dla każdej z trzech głównych stref/sektorów miasta postsocjalistycznego ujawniają intrygujące różnice pomiędzy miastami Północy, Centrum i Południa byłego Bloku Wschodniego (rys. 9). Wyższe kategorie społeczne są najsilniej skoncentrowane przestrzennie w śródmieściu Bukaresztu, a najmniej w strefie wewnętrznej Tallina. Innymi słowy, w strefie śródmiejskiej Bukaresztu ponad połowa wszystkich mieszkańców należących do wyższej kategorii społecznej mieszkała w jednostkach przestrzennych, gdzie kategoria ta stanowiła ponad połowę ogółu mieszkańców. Dla porównania w strefie wewnętrznej Warszawy, w sąsiedztwach tego typu mieszkało $10 \%$ wszystkich członków wyższej kategorii społecznej, a w Tallinie udział ten wynosił tylko 2\%. Wyniki jednoznacznie wskazują, że skala śródmiejskiej koncentracji mieszkaniowej wyższych kategorii społecznych w spektrum byłych miast socjalistycznych maleje zatem na linii południe-północ. Różnice te mogą wynikać nie tylko ze wzorów odziedziczonych z epoki przedsocjalistycznej i socjalistycznej, ale także z odmienności instytucjonalnych oraz tempa przemian stref centralnych po 1990 roku.

O ile wzory koncentracji przestrzennej średnich kategorii społecznych w strefach śródmiejskich trzech stolic nie wskazują na większe pomiędzy nimi różnice, obraz jaki wyłania się dla niższych kategorii prezentuje całkiem odmienną zależność. Otóż niższe kategorie społeczne najsilniej skoncentrowane były w śródmieściu Tallina. W stolicy Estonii 20\% wszystkich mieszkańców zaliczanych do niższych grup społecznych mieszkało w jednostkach zdominowanych przez własną kategorię (rys. 9), z kolei w strefie śródmiejskiej Warszawy wartość ta wynosiła $6 \%$. 

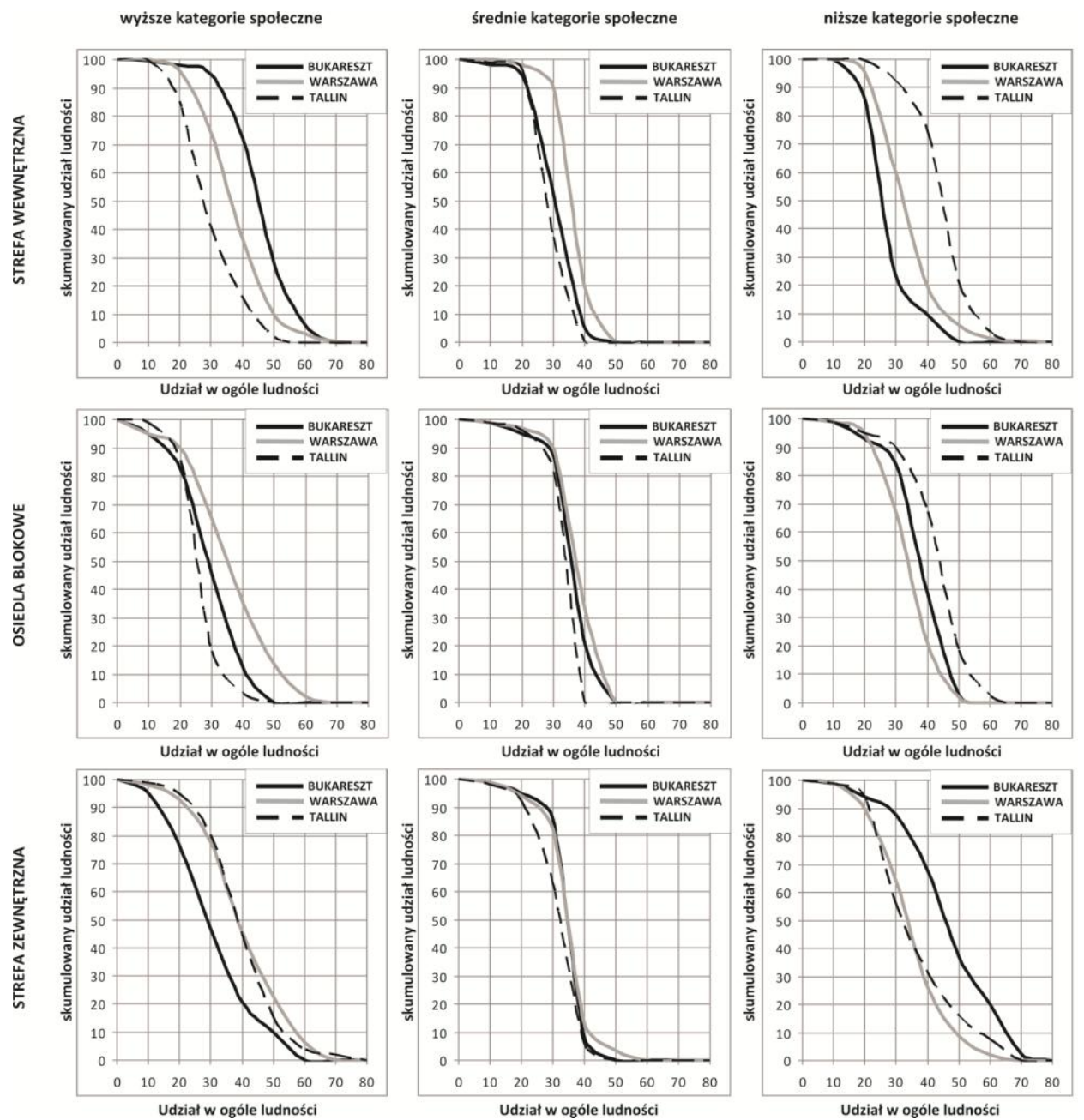

Rysunek 9: Profile koncentracji dla trzech kategorii społecznych w głównych strefach i sektorach Bukaresztu, Warszawy i Tallina na początku XXI wieku.

Źródło: Opracowanie własne na podstawie wyników spisów powszechnych: Rumunia (2002), Polska (2002), Estonia (2000)

W Bukareszcie nie stwierdzono występowania tego typu enklaw mieszkaniowych. Stąd też, biorąc pod uwagę różnice pomiędzy poszczególnymi re- 
gionami dawnej „Europy Wschodniej” można przyjąć, że poziom koncentracji przestrzennej niższych kategorii społecznych w strefie wewnętrznej miasta postsocjalistycznego maleje z północy na południe.

Różnice w przebiegu krzywych koncentracji dla obszarów zaliczonych do „osiedli blokowych” nie pokrywają się z tymi, które zaobserwowano dla stref wewnętrznych. W sektorach i wyspach gęstej zabudowy wielorodzinnej z okresu socjalistycznego najwyższy poziom koncentracji wyższych kategorii społecznych zanotowano w przypadku Warszawy. Tylko w tym mieście istniały osiedla, w których kategorie te dominowały w ogóle aktywnych zawodowo mieszkańców. W celu wytłumaczenia zaobserwowanych wzorów raz jeszcze odwołać się można do dziedzictwa polityki mieszkaniowej okresu socjalizmu, a zwłaszcza jej wzrastającej elitaryzacji (Węcławowicz 1988). W Warszawie (Ciechocińska 1987), ale też w Bukareszcie (Chelcea 2012), przed 1989 rokiem sprawnie działały spółdzielnie mieszkaniowe promujące ówczesną „klasę średnią”, oferując w zamian „kontrolowane” prawo własności prywatnej. W byłym Związku Radzieckim spółdzielcze zasoby mieszkaniowe miały bardziej ograniczone znaczenie i cechowały się większym rozproszeniem przestrzennym, a znacznie większą rolę miały budynki i osiedla wznoszone przez zakłady przemysłowe (Bater 1989, French 1996). Ponadto patrząc na poziomy koncentracji wyższych i średnich kategorii społecznych w socjalistycznych osiedlach mieszkaniowych w Warszawie i w Bukareszcie trudno zgodzić się z twierdzeniem głoszonym przez I. Szelenyi (1996), o przeobrażeniu tych obszarów w „slumsy” XXI wieku. Jednak zaznaczyć także należy, że w Tallinie, pomimo heterogenicznego społecznie składu mieszkańców osiedli mieszkaniowych, poziom koncentracji niższych kategorii społecznych dorównywał wartości zanotowanej w przypadku strefy śródmiejskiej.

Różnice we wzorach koncentracji przestrzennej grup społecznych w strefie zewnętrznej wpisują się w schemat oczekiwany dzięki dokonanemu przeglądowi literatury. Przede wszystkim najniższy poziom koncentracji wyższych kategorii społecznych i najwyższy poziom koncentracji kategorii niższych na peryferiach Bukaresztu potwierdza argumenty o generalnie niskim statusie strefy zewnętrznej wielkich miast Europy Południowo-Wschodniej (Marcińczak i inni 2013b). W Warszawie i Tallinie na obszarach tych najsilniej skoncentrowani byli mieszkańcy zaliczani do górnych grup hierarchii społecznej (rys. 9). Decydować o tym mógł szybki rozwój procesu suburbanizacji, który w początkowym okresie objął obszary peryferyjne $w$ granicach administracyjnych miast (Węcławowicz 2008, Leetmaa i inni 2009, Marcińczak 2012).

Na zakończenie rozważań nad poziomem i „globalnymi” wzorami segregacji społecznej w mieście postsocjalistycznym warto podkreślić jeszcze jeden wnio- 
sek na temat natury badanego zjawiska w tej części Europy. Konfrontując ze sobą wyniki analizy poziomu separacji społecznej oraz rezultaty badań nad skalą koncentracji przestrzennej stwierdzić można istnienie dosyć zaskakującej zależności, która cechowała Warszawę i Tallin. Jednakże przy uwzględnieniu dosyć ogólnego podziału miasta postsocjalistycznego na trzy główne strefy/sektory, zmienność poziomu separacji nie zawsze idzie w parze ze zmiennością koncentracji. Dobrze ilustruje to przykład Bukaresztu, gdzie pomimo ogólnie rosnącego poziomu separacji społecznej wraz z odległością od centrum, poziom koncentracji przestrzennej wyższych grup społecznych maleje. 


\title{
Rozdzial 6
}

\author{
„Ztote Wybrzeże” $i$,slums” \\ Lokalne wzory segregacji spotecznej w Bukareszcie, Tallinie i Warszawie \\ po socjalizmie
}

Tytuł tego rozdziału wprost nawiązuje do pracy jednego z klasyków szkoły chicagowskiej, a mianowicie H. W. Zorbauga (1929/1976), który jako pierwszy zwrócił uwagę na mozaikę sąsiadujących ze sobą w przestrzeni wielkiego miasta światów, często o diametralnie różnym statusie społecznym (nawet $\mathrm{w}$ ramach geometrycznego uporządkowania struktury społeczno-przestrzennej w postaci koncentrycznych stref). W Chicago lat 1920. bogata dzielnica położona nad jeziorem Michigan otoczona była slumsem, a wyraźną jej granicę stanowiły pojedyncze ulice. Terminu „mozaika” użyto także do opisu struktury społecznoprzestrzennej miasta socjalistycznego (Węcławowicz 1988). Biorąc zatem pod uwagę wyraźny wzrost nierówności społecznych po 1990 roku w byłych krajach socjalistycznych, przy niskim poziomie segregacji społecznej spodziewać się można relatywnego wymieszania przestrzennego poszczególnych kategorii społecznych albo też wzrostu dystansu społecznego, przy zachowaniu lub kurczeniu się dystansu przestrzennego - jest to paradoks segregacji posocjalistycznej. Paradoks ten sygnalizować może także fragmentację społeczną w mikroskali przestrzennej jednostek statystycznych. „Złote wybrzeża” i „slumsy” w mieście postsocjalistycznym dzielić mogą zatem nie poszczególne ulice, ale granice działek miejskich lub ściany mieszkań.

Odpowiedzi na pytanie, na ile mozaikowa struktura zróżnicowań społecznoprzestrzennych charakterystyczna dla miasta socjalistycznego jest czytelna po upadku systemu w największych metropoliach głównych regionów postsocjalistycznej Europy, dostarczą zaprezentowane poniżej wyniki analizy lokalnych wzorów koncentracji przestrzennej. Wzory te badane są w oparciu o podział ludności aktywnej ekonomicznie na trzy podstawowe grupy, podobnie jak miało to miejsce w przypadku profili koncentracji, a więc kategorie: wyższą, średnią oraz niższą. W celu wyznaczenia obszarów koncentracji poszczególnych kategorii społecznych skorzystano z prezentowanego w sekcji metodycznej opracowania wskaźnika lokalizacji $(L Q)$. W analizach przyjęto, że wartość tego wskaźnika powyżej dwóch odchyleń standardowych wskazuje na koncentrację, a wartości większe niż trzy odchylenia standardowe oznaczają silną koncentrację (por. Marcińczak 2012). 
Lokalne wzory koncentracji przestrzennej wyższych kategorii społecznych w trzech postsocjalistycznych metropoliach wymykają się łatwym uogólnieniom, które sugerują czytelne uporządkowanie w postaci geometrycznych stref i sektorów. Pomimo tego, że można wyróżnić ich elementy w obrazie rozmieszczenia wyższych warstw społecznych, to jednak pod tym względem przeważają w przestrzeni Bukaresztu, Warszawy i Tallina pojedyncze, zlokalizowane wyspowo jednostki statystyczne (zwłaszcza te $\mathrm{z}$ silną koncentracją badanej grupy) (rys. 10). Co istotniejsze, lokalne wzory koncentracji tej kategorii społecznej $\mathrm{w}$ trzech miastach są w zasadzie od siebie odmienne - nie ma jednego, generalizującego trendu przestrzennego. Nawet pomimo braku wyraźnych zbieżności we wzorach przestrzennych pomiędzy miastami, szczegółowa analiza każdej ze stolic ujawnia zaskakujące podobieństwa pomiędzy Bukaresztem, Warszawą i Tallinem, które z kolei wskazywać mogą na pewną „uniwersalność” zjawiska segregacji w spektrum byłych miast postsocjalistycznych - zarówno tych z południa, centrum, jak i północy dawnej „Europy Wschodniej”. Ta „uniwersalność", jak będzie to przedstawione poniżej, odnosi się także do lokalnych wzorów koncentracji pozostałych kategorii społecznych.

W Bukareszcie rozmieszczenie przestrzenne wyższej kategorii społecznej wydaje się najbardziej nawiązywać do geometrycznych układów znanych z modeli „klasycznych”, zwłaszcza koncentrycznego i sektorowego (rys. 10). Świadczy o tym wyraźne skupienie w strefie śródmiejskiej (a dokładniej w jej części północnej) jednostek przestrzennych, które charakteryzują się silną koncentracją wyższych grup społecznych. Są to obszary o dobrych i bardzo dobrych warunkach mieszkaniowych, w których zlokalizowane są wysokiej klasy kamienice oraz wieżowce wzniesione dla nomenklatury w latach 1980. Z tego „rdzenia” promieniście rozchodzą się sektory o wysokim statusie społecznym. Zabudowę tych terenów stanowią z jednej strony wille z okresu przedsocjalistycznego (sektor północny obejmujący osiedla Floreasca oraz Primaveri), z drugiej strony zaś osiedla mieszkaniowe z lat 1970. i 1980 (sektory wschodni i zachodni). Tam jednak poziom koncentracji wyższych kategorii społecznych był słabszy. Strefa zewnętrzna, oprócz osiedli willowych zlokalizowanych w jej części północnej, pozbawiona była jednostek statystycznych, gdzie istotnie reprezentowane byłyby kategorie $\mathrm{z}$ wierzchołka piramidy społecznej.

Obraz lokalnych wzorów koncentracji wyższej kategorii społecznej w Tallinie ilustruje rozmieszczenie znacznie różniące się od wykrytego w Bukareszcie (rys. 10). Z wyjątkiem historycznego rdzenia, gdzie wyraźnie skoncentrowana była ludność o wysokim statusie społeczno-materialnym, w strefie wewnętrznej Tallina tylko nieliczne jednostki przestrzenne cechowały się wyższym statusem społecznym. Sąsiedztwa tego typu nie były też często reprezentowane w sek- 
torach osiedli blokowych. Wyższe grupy społeczne zajmowały zwłaszcza strefę zewnętrzną, tworząc mozaikę społeczno-przestrzenną, dającą się wpisać w trzy ogólne sektory: północno-wschodni i północno-zachodni oraz południowy (rys. 10). Geneza wysokiego statusu społecznego tych obszarów sięga okresu przedsocjalistycznego, gdy na dawnych peryferiach wznoszono wille - znakomitym przykładem jest dawne miasto-ogród, dzisiejsza południowa dzielnica Tallina Nõmme. Wyższe grupy społeczne wznosiły tam domy jednorodzinne także w okresie socjalistycznym, a proces ten nabrał tempa po 1990 roku (Leetmaa i Tammaru 2009).

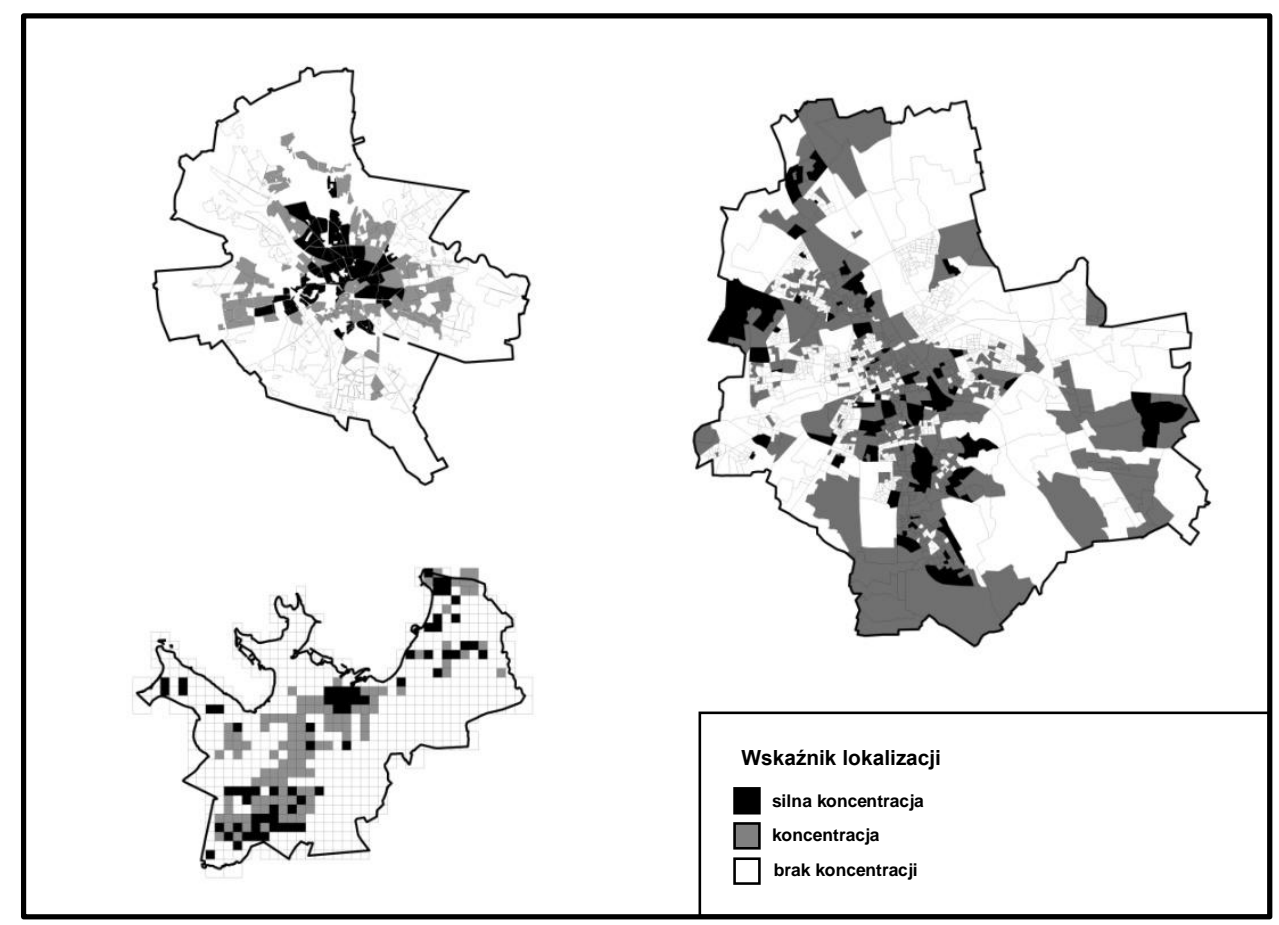

Rysunek 10: Koncentracja przestrzenna wyższych kategorii społecznych w Bukareszcie, Warszawie i Tallinie na początku XXI wieku.

Źródto: Opracowanie własne na podstawie wyników spisów powszechnych: Rumunia (2002), Polska (2002), Estonia (2000) 
Wzory, w jakie układają się lokalne obszary koncentracji wyższych kategorii społecznych w Warszawie, usytuować można pomiędzy tymi znanymi z Bukaresztu a tymi $\mathrm{z}$ Tallina. $\mathrm{Z}$ jednej strony ludność o wyższym statusie była skoncentrowana, bądź silnie skoncentrowana w strefie śródmiejskiej Warszawy zarówno w ścisłym centrum miasta (dzielnica Śródmieście), ale też na dużych obszarach Mokotowa, Żoliborza i Ochoty. Z drugiej strony zaś, w odróżnieniu od Tallina a podobnie do Bukaresztu, analizowana kategoria mieszkańców zajmowała także jednostki przestrzenne na obszarach wielkich osiedli mieszkaniowych, głównie z lat 1970. i 1980. (na Ursynowie, Bemowie i Bielanach). Jednak w odróżnieniu od stolicy Rumunii, w największej polskiej metropolii grupy o wyższym statusie społecznym skoncentrowane były też w wybranych jednostkach strefy zewnętrznej, na Ursynowie, Białołęce i w Wesołej. W zagospodarowaniu tych terenów dominuje zabudowa willowa $\mathrm{z}$ różnych okresów, ale też budynki wielorodzinne z końca lat 1980. oraz pierwszej dekady okresu postsocjalistycznego. Pomimo identyfikacji kilku wyraźnych skupień przestrzennych jednostek o wysokim statusie społecznym, przestrzeń Warszawy cechowała struktura mozaikowa.

Analiza poziomu separacji wskazała, że średnie kategorie społeczne są bardziej segregowane od kategorii wyższych niż od kategorii niższych. Wzory koncentracji przestrzennej ludności o średnim statusie społeczno-materialnym prezentuje rysunek 11. Także w tym przypadku zmienności przestrzennej analizowanej grupy społecznej nie da się opisać generalnym modelem. Jednakże w każdej z postsocjalistycznych stolic jedna cecha lokalnych wzorów koncentracji przestrzennej średnich kategorii wydaje się mieć charakter uogólniającego trendu - w odróżnieniu od wyższych kategorii społecznych, lokalny poziom koncentracji był w ich przypadku znacznie słabszy. Poza nielicznymi wyjątkami, mieszkańcy o średnim statusie społecznym nie zamieszkiwali w jednostkach, w których udział tej grupy wskazywałby na silną koncentrację. Rezultat ten potwierdza zatem wyniki analizy separacji, które wskazały, że grupy społeczno-zawodowe należące do kategorii średniej cechowały najniższe poziomy segregacji w każdym z miast. Innymi słowy, to właśnie ta grupa ludności miasta postsocjalistycznego mieszka w jednostkach najbardziej heterogenicznych społecznie.

W stolicy Rumunii ludność o średnim statusie społecznym koncentrowała się w jednostkach, które układały się w prawie regularną strefę otaczającą śródmieście. $\mathrm{Z}$ jednej strony były to tereny zabudowy jedno- $\mathrm{i}$ wielorodzinnej $\mathrm{z}$ okresu przedsocjalistycznego i socjalistycznego, której standard zdecydowanie odbiegał od tego w osiedlach willowych, ale nadał był dobry. $Z$ drugiej strony zaś obszarami, na których skoncentrowane były średnie grupy społeczne, były również osiedla, głównie te z lat 1960. i początku lat 1970. - Obor, Militari czy Rahova 
(rys. 11). Miały one zazwyczaj niższy standard od osiedli, w których silnie skoncentrowana była kategoria wyższa.

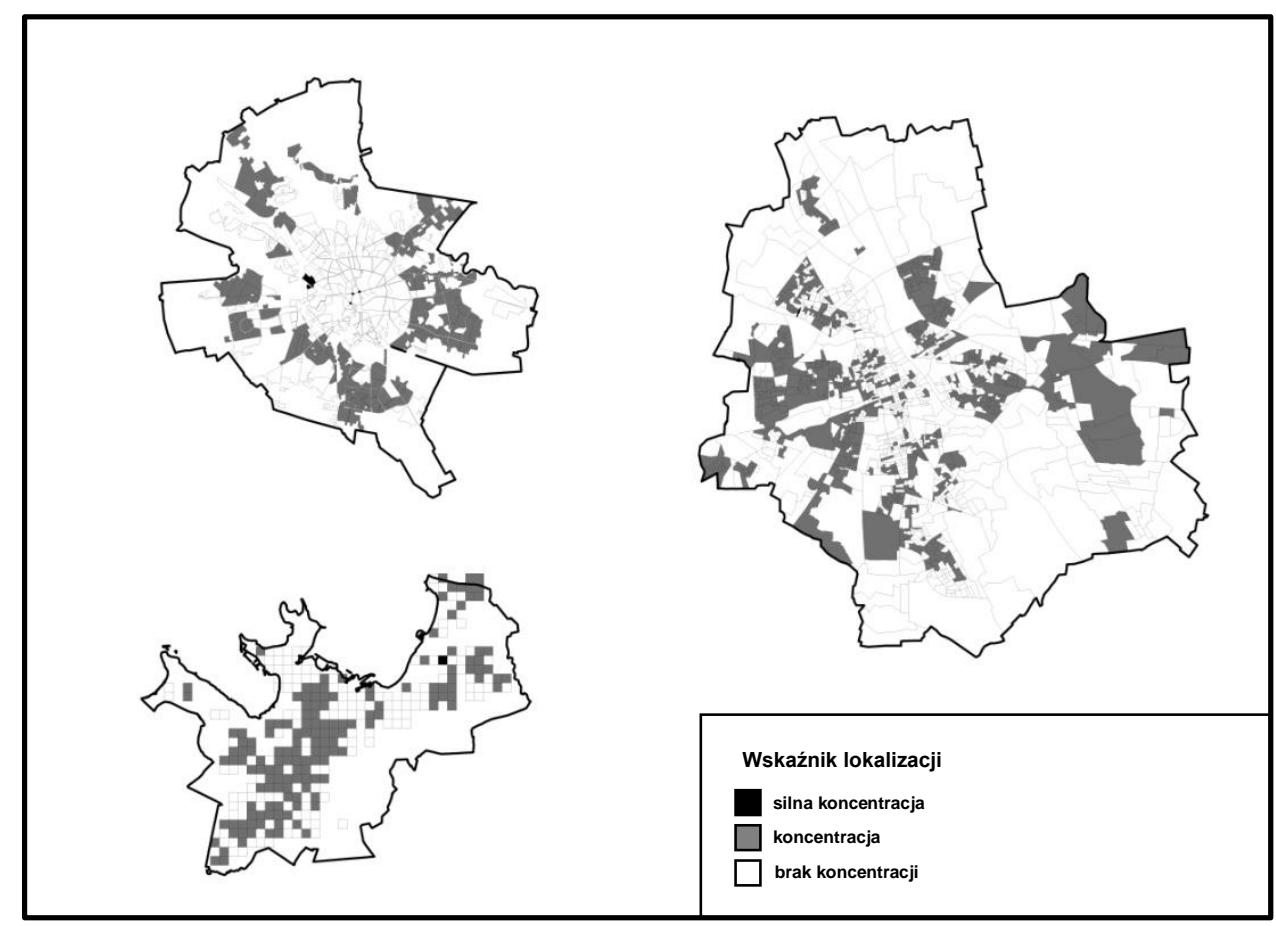

Rysunek 11: Koncentracja przestrzenna średniej kategorii społecznej w Bukareszcie, Warszawie i Tallinie na początku XXI wieku.

Źródto: Opracowanie własne na podstawie wyników spisów powszechnych: Rumunia (2002), Polska (2002), Estonia (2000)

Podobnie do układu przestrzennego koncentracji średniej kategorii społecznej w Bukareszcie wyglądało rozmieszczenie tej grupy mieszkańców w Warszawie. W stolicy Polski średnia kategoria społeczna skoncentrowana była w zabudowie jednorodzinnej $\mathrm{w}$ strefie zewnętrznej oraz $\mathrm{w}$ wielorodzinnym, osiedlowym budownictwie blokowym, wzniesionym z zastosowaniem prefabrykatów. Jednak, w odróżnieniu od stolicy Rumunii, w Warszawie lokalne wzory koncentracji ludności o średnim statusie społecznym silnie nawiązywały do rozmieszczenia kategorii wyższej. Zbieżność ta dotyczy zwłaszcza osiedli blokowych. 
W Tallinie, podobnie jak w Warszawie, rozmieszczenie średniej kategorii społecznej nawiązuje do struktury mozaikowej (rys. 11). Ponadto, w porównaniu do Warszawy i Bukaresztu, w Tallinie ta grupa społeczna wydaje się być najbardziej równomiernie rozmieszczona i reprezentowana w każdej z głównych stref miasta. Mimo tego można wyznaczyć obszary skupiające jednostki przestrzenne o istotnej jej koncentracji. Są to strefa wewnętrzna (oprócz ścisłego centrum) oraz osiedla blokowe, zwłaszcza te z lat 1960. (np. Mustamäe). W strefie zewnętrznej wzory koncentracji kategorii średnich w zasadzie powielają te, które cechowały ludność o wyższym statusie.

Niższe kategorie społeczne, grupy społeczno-zawodowe często zaliczane do „przegranych” w wyniku transformacji ustrojowej (Domański 2004, Węcławowicz 2004), najsilniej separowane przestrzennie były od „wygranych”, a więc kategorii wyższych. Stąd też wzory przestrzenne koncentracji mieszkaniowej ludności o niskim statusie społecznym w zasadzie nie pokrywają się z obszarami, gdzie silnie reprezentowana jest kategoria wyższa (rys. 12). Jednak w każdej z metropolii (głównie w strefie zewnętrznej, ale także w wewnętrznej) wskazać można jednostkę (jednostki), które stanowiły miejsce (silnej) koncentracji kategorii wyższych i niskich, a więc przeciwległych krańców hierarchii społecznej. Taka zbieżność wskazywać może na rozwój zjawiska fragmentacji społecznoprzestrzennej.

W Bukareszcie, w zasadzie z pojedynczymi wyjątkami, niższe grupy społeczne skoncentrowane były w strefie zewnętrznej (rys. 12). Już przed wprowadzeniem socjalizmu, ale także w czasie trwania tego systemu, peryferia stolicy $\mathrm{Ru}$ munii stanowiły przyczółek najniższych kategorii społecznych, których jedyną szansą na zamieszkanie w mieście było wzniesienie nielegalnego domu, zazwyczaj o substandardowych warunkach. W pierwszej dekadzie po upadku systemu powolna transformacja oraz brak rozwiązań instytucjonalnych dotyczących prawa własności doprowadziły do petryfikacji odziedziczonej struktury społecznej (zwłaszcza na peryferiach). Podobną genezę, czyli dziedzictwo socjalizmu połączone z inercją pierwszych lat transformacji, ma także enklawa niskich kategorii społecznych w strefie wewnętrznej, w ścisłym „nowym” centrum miasta. Zabudowę tego obszaru stanowią kamienice, przeznaczone do rozbiórki już w okresie wielkiej socjalistycznej przebudowy centrum, które ze względu na brak funduszy ominął los sąsiednich budynków. W pierwszych latach przemian systemowych teren ten został nielegalnie zajęty przez ludność romską oraz bezdomnych (Marcińczak i inni 2013b). Jeszcze innym ciekawym przykładem silnej koncentracji mieszkańców należących do niskich grup społecznych jest dzielnica Ferentari, gdzie bloki z lat 1960. są wymieszane z nielegalną substandardową zabudową, wciśniętą pomiędzy tereny przemysłowo-składowe. 
Jako prawdziwe „getto” wykluczonych społecznie można określić małą grupę byłych hoteli robotniczych i bloków o bardzo niskim standardzie, także zlokalizowanych w dzielnicy Ferentari (ibid.), zajętych nielegalnie we wczesnych latach 1990. przez ludność wykluczoną społecznie.

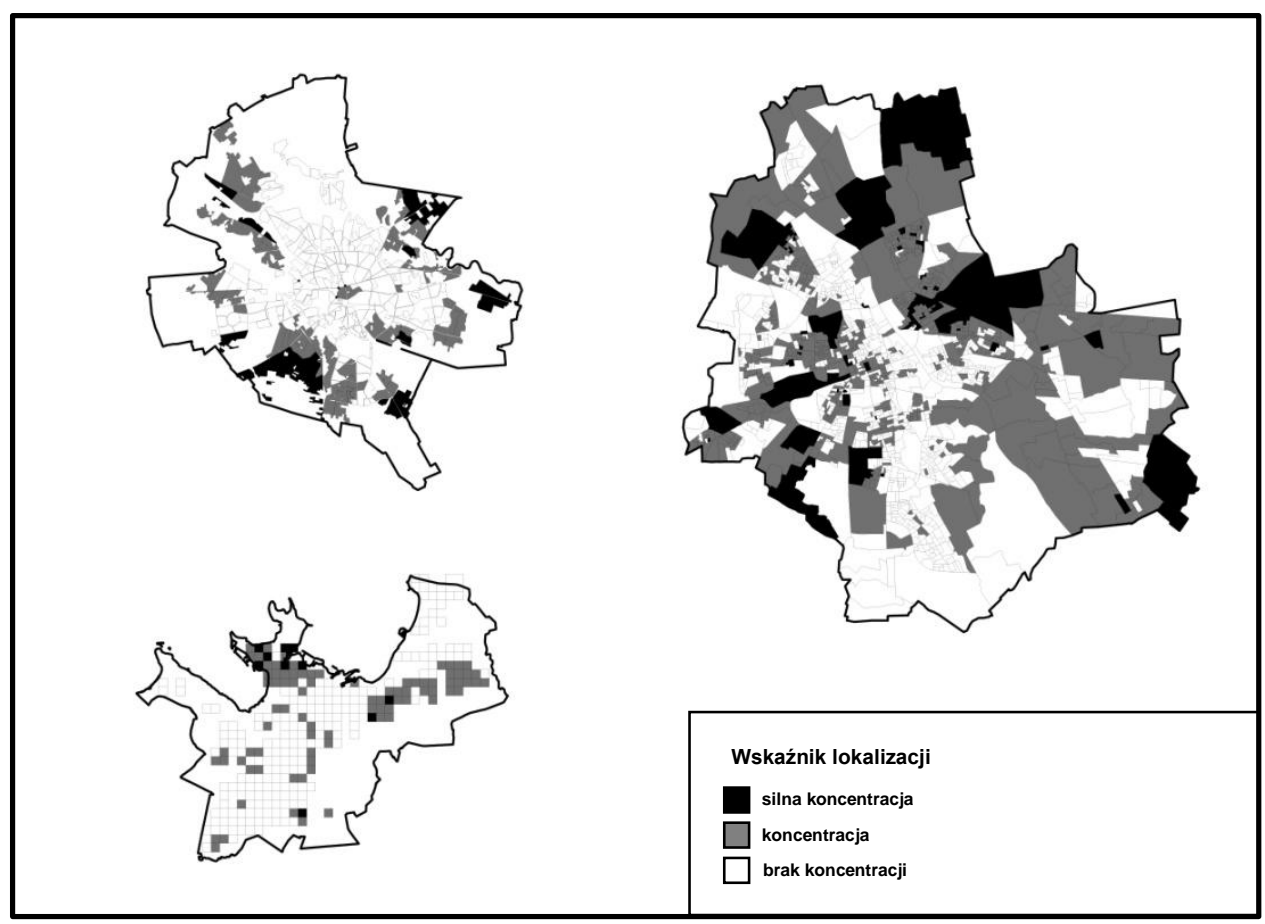

Rysunek 12: Koncentracja przestrzenna niskiej kategorii społecznej w Bukareszcie, Warszawie i Tallinie początku XXI wieku.

Źródto: Opracowanie własne na podstawie wyników spisów powszechnych: Rumunia (2002), Polska (2002), Estonia (2000)

Również w Tallinie miejsca koncentracji i silnej koncentracji tłumaczyć można dziedzictwem socjalizmu. W odróżnieniu od Bukaresztu, w estońskiej metropolii niskie kategorie społeczne znacznie silniej reprezentowane są w strefie wewnętrznej, a co bardziej zaskakujące, na największym w mieście osiedlu blokowym z lat 1970. i 1980. - Lasnamäe (rys. 12). Dla porównania, w Warszawie 
oraz Bukareszcie bloki z tego okresu skupiały wyższe i średnie kategorie społeczne. W dzielnicy Lasnamäe, $\mathrm{z}$ uwagi na silny napływ Rosjan w późnym okresie socjalistycznym, koncentracja niskich kategorii społecznych w wybranych jednostkach może mieć także wymiar etniczny. W przypadku strefy wewnętrznej miejscem silnej koncentracji omawianej grupy ludności był północny półwysep. Już w okresie przed drugą wojną światową, w drewnianych domach wielorodzinnych zamieszkiwała tam ludność robotnicza. Wzór ten nie uległ zmianom przez półwiecze epoki socjalistycznej, ale też pierwszą dekadę po upadku systemu. Z kolei starsze osiedla blokowe oraz strefa zewnętrzna tylko sporadycznie były miejscami koncentracji niskich grup społecznych.

Obraz, jaki ujawniła analiza lokalnych wzorów koncentracji ludności o niskim statusie społeczno-materialnym w Warszawie, wskazuje na nieco odmienny schemat przestrzenny. Podobnie jak i w dwóch pozostałych metropoliach, miejsca koncentracji „przegranych” w procesie transformacji układają się we wzór zbliżony do mozaiki i są obecne w każdej z trzech głównych stref/sektorów (rys. 12). W strefie wewnętrznej były to obszary zabudowane kamienicami na Pradze Północ i Południe, które ocalały ze zniszczeń wojennych, ale też niektóre osiedla blokowe Woli oraz rezydualna stara zabudowa o niskim standardzie. Na obszarze osiedli mieszkaniowych, które wznoszono na wolnych terenach w strefie zewnętrznej miasta począwszy od późnych lat 1960., niskie kategorie społeczne skoncentrowane były w pobliżu huty na Bielanach, ale też w blokach niektórych osiedli na Targówku. W strefie zewnętrznej natomiast, mieszkańcy z dołu hierarchii społecznej zamieszkiwali przeważnie w budynkach o charakterze wiejskim na peryferyjnych obszarach dzielnic Białołęka, Wawer i Włochy (por. Węcławowicz 2001). Podsumowując rezultaty analizy lokalnych wzorów koncentracji niższych kategorii społecznych w Warszawie stwierdzić można, że podobnie jak i w pozostałych miastach, stoi za nimi dziedzictwo socjalizmu, a zwłaszcza polityki związanej z rozwojem przestrzennym i polityką mieszkaniową.

Jak zostało to zasygnalizowane na wstępie tego rozdziału, analiza lokalnych wzorów koncentracji za pomocą wskaźnika lokalizacji $(L Q)$ stanowi rozszerzenie badań nad globalnymi wzorami segregacji (separacji i koncentracji) społeczno-przestrzennej. Studia nad wzorami rozmieszczenia poszczególnych grup społecznych dodają zatem istotną porcję informacji, której nie dostarczają, z reguły „nieczułe" przestrzennie, tradycyjne indeksy segregacji oraz profile koncentracji. Ujawniając „geografię” podziałów społecznych, analiza wzorów lokalnych stanowi istotny element i narzędzie badawcze, bez którego obraz poziomu, skali i wzorów segregacji społecznej w mieście nie byłby pełny. Ilustracja wzorów koncentracji głównych kategorii społecznych w trzech postsocjalistycznych metropoliach pozwoliła wskazać podobieństwa i różnice w strukturze podziałów 
społeczno-przestrzennych w miastach reprezentujących różne odcienie socjalizmu, jak również transformacji systemowej, a tym samym dokładniej poznać poziom, skalę i geografię segregacji społecznej w mieście postsocjalistycznym.

Rezultaty z Bukaresztu, Warszawy i Tallina wskazują na brak możliwości sformułowania (konstrukcji) modelu, który opisałby w sposób syntetyczny strukturę społeczno-przestrzenną miasta postsocjalistycznego. Chociaż w każdej z metropolii łatwo dało się wyróżnić trzy główne, odmienne morfologicznie i funkcjonalnie strefy/sektory, to jednak nie można jednoznacznie stwierdzić uniwersalnego gradientu statusu społecznego mieszkańców w mieście „Europy Wschodniej” na początku XXI wieku. W każdej ze stolic obszary o wyraźnym wysokim, średnim lub niskim statusie społecznym mieszkańców skoncentrowane były w nieco inny sposób. Największe różnice w wewnątrzmiejskiej geografii podziałów społecznych cechują Bukareszt i Tallin, a więc metropolie północy i południa „Europy Wschodniej”. $Z$ dużym uproszczeniem można powiedzieć, że obraz lokalnych wzorów koncentracji społecznej z Tallina stanowi „negatyw” obrazu z Bukaresztu. Z kolei Warszawę, jedno z największych miast Europy Środkowej, cechuje rozmieszczenie kategorii społecznych stanowiące „hybrydę" wzorów znanych ze stolic Rumunii i Estonii.

Oprócz zasadniczych różnic $\mathrm{w}$ poziomie, skali i wzorach lokalnych segregacji społecznej $\mathrm{w}$ miastach $\mathrm{z}$ północy, centrum i południa „Europy Wschodniej”, istnieje jedno kluczowe podobieństwo cechujące geografię tego zjawiska w mieście postsocjalistycznym. Jest nim mozaikowa struktura społecznoprzestrzenna metropolii położonych na wschód od byłej ,żelaznej kurtyny”. Ponadto, w każdym z miast rozmieszczenie różnych kategorii społecznych w ramach mozaiki zróżnicowanych warunków mieszkaniowych silnie nawiązywało do lokalnego kontekstu, wytworzonego przed nastaniem socjalizmu oraz w trakcie jego trwania. Epoka postsocjalistyczna, z racji kryzysu ekonomicznego z początku lat 1990. oraz jej krótkiego jak dotąd trwania, wywołała mniej znaczące zmiany w przestrzeni omawianych miast.

Konfrontacja wzorów koncentracji trzech głównych kategorii społecznych z ogólnym opisem ewolucji struktur społeczno-przestrzennych Bukaresztu, Tallina i Warszawy, ujawnia intrygujące fakty dotyczące geografii podziałów społecznych w mieście postsocjalistycznym, bez względu na jego położenie w ramach „Europy Wschodniej”. Zarówno miejsca koncentracji kategorii wyższych, jak i te, w których silnie reprezentowane były kategorie niższe, w znacznej mierze reprodukowały odziedziczony status społeczny. Przedwojenne osiedla willowe oraz luksusowe kamienice w strefie wewnętrznej i zewnętrznej zachowały swój wysoki status społeczny pomimo dwukrotnej, radykalnej zmiany systemu politycznego, gospodarczego i społecznego. Podobny los cechował kamienice 
i domy o niskim standardzie, które, o ile nie zostały wyburzone w celu stworzenia miejsca dla nowych osiedli blokowych, zachowały niski status społeczny.

Z wyjątkiem Tallina, gdzie zróżnicowania społeczno-materialne mogą mieć podłoże etniczne, skład społeczny wielkich kompleksów mieszkaniowych nadal odzwierciedlał upadek idei egalitaryzmu społecznego w dostępie do zasobów mieszkaniowych w późniejszym okresie socjalistycznym (por. Węcławowicz 1988) - na początku XXI wieku „nowsze” osiedla mieszkaniowe (z lat 1970. i 1980.) zamieszkane były zazwyczaj przez ludność o wyższym statusie społecznym niż mieszkańcy osiedli z końca lat 1950 i 1960.

Okres postsocjalistyczny najsilniejszy wpływ w każdym z miast wywarł na wzory koncentracji wyższych kategorii społecznych w strefie zewnętrznej dobrze ilustrują to przykłady Tallina i Warszawy, gdzie łatwo dostępne tereny mieszkaniowe $\mathrm{w}$ granicach administracyjnych miast $\mathrm{w}$ pierwszej kolejności skupiły uwagę deweloperów i inwestorów indywidualnych. 


\section{Rozdzial 7}

\section{„Paradoks” segregacji spotecznej po socjalizmie Podsumowanie i wnioski}

W kontekście braku studiów porównawczych nad zjawiskiem podziałów społeczno-przestrzennych $\mathrm{w}$ zbiorze byłych europejskich krajów socjalistycznych, głównym celem niniejszego opracowania było dokładne ustalenie poziomu, skali i wzorów przestrzennych segregacji społecznej w trzech postsocjalistycznych metropoliach, które reprezentują odmienne ścieżki rozwoju zarówno przed, w trakcie, jak i po zakończeniu socjalizmu. Na podstawie przeglądu koncepcji teoretycznych wyjaśniających rozwój i poziom zjawiska segregacji społecznej w wielkim mieście założono, że metropolie postsocjalistyczne, które cechuje wyższy poziom globalizacji i liberalizacji gospodarki po 1990 roku (tertiaryzacja, przede wszystkim rozwój sektora usług finansowych oraz deindustrializacja), jak również związany z nimi wyższy poziom nierówności społecznych, powinny być także bardziej segregowane społeczno-przestrzennie niż miasta, w których przemiany systemowe i towarzyszące im zmiany społeczne przebiegały wolniej. W konsekwencji dokonano dokładnej analizy poziomu, skali i geografii zjawiska segregacji w Bukareszcie, Warszawie i Tallinie na początku XXI wieku. W celu operacjonalizacji badań zjawisko segregacji społecznej zdefiniowano jako globalne i lokalne wzory separacji i koncentracji poszczególnych grup społeczno-zawodowych i kategorii społecznych. Dobór trzech stolic miał za zadanie ilustrację natury podziałów społeczno-przestrzennych w trzech głównych regionach byłej „Europy Wschodniej”, które różni nie tylko nieco odmienne dziedzictwo socjalizmu, ale też tempo i charakter przemian po upadku systemu (kraje bałtyckie, Europa Środkowo-Wschodnia oraz Europa PołudniowoWschodnia).

Biorąc pod uwagę dominujący w literaturze przedmiotu argument o polaryzacji społecznej i wzroście podziałów społecznych i przestrzennych w mieście „Europy Wschodniej” po 1990 roku, najistotniejszym rezultatem tej pracy jest szczegółowe ustalenie rozmiaru segregacji społeczno-przestrzennej, który określić należy jako niski lub średni. Tym samym, nawet $\boldsymbol{w}$ skali relatywnie malych oraz homogenicznych funkcjonalnie i morfologicznie jednostek przestrzennych, dla których zagregowano dane ludnościowe, nie znaleziono dowodów na poparcie argumentów o polaryzacji spoleczno-przestrzennej $w$ mieście postsocjalistycznym. Miasto postsocjalistyczne jest nadal obszarem heterogenicznym społecznie. Dla przypomnienia, dalszych argumentów na poparcie tezy o wy- 
mieszaniu społeczno-przestrzennym w mieście „Europy Wschodniej” dostarcza porównanie $\mathrm{z}$ innymi wielkimi miastami kapitalistycznymi. $\mathrm{Z}$ uwagi na dostępne w literaturze materiały porównawcze (Musterd 2005), osadzenie wyników $\mathrm{z}$ trzech badanych metropolii $\mathrm{w}$ szerszej perspektywie segregacji społecznej po obu stronach Atlantyku możliwe jest jedynie dla niższych kategorii społecznych (rys. 13). To proste ćwiczenie w sposób czytelny wskazuje, że nawet w skrajnym przypadku (Bukareszt) poziom segregacji w mieście postsocjalistycznym mieścił się w ramach europejskiej średniej i był tym samym znacznie niższy niż w miastach Stanów Zjednoczonych, znanych z wysokiego poziomu nierówności, a nawet polaryzacji społecznej (społeczno-przestrzennej).

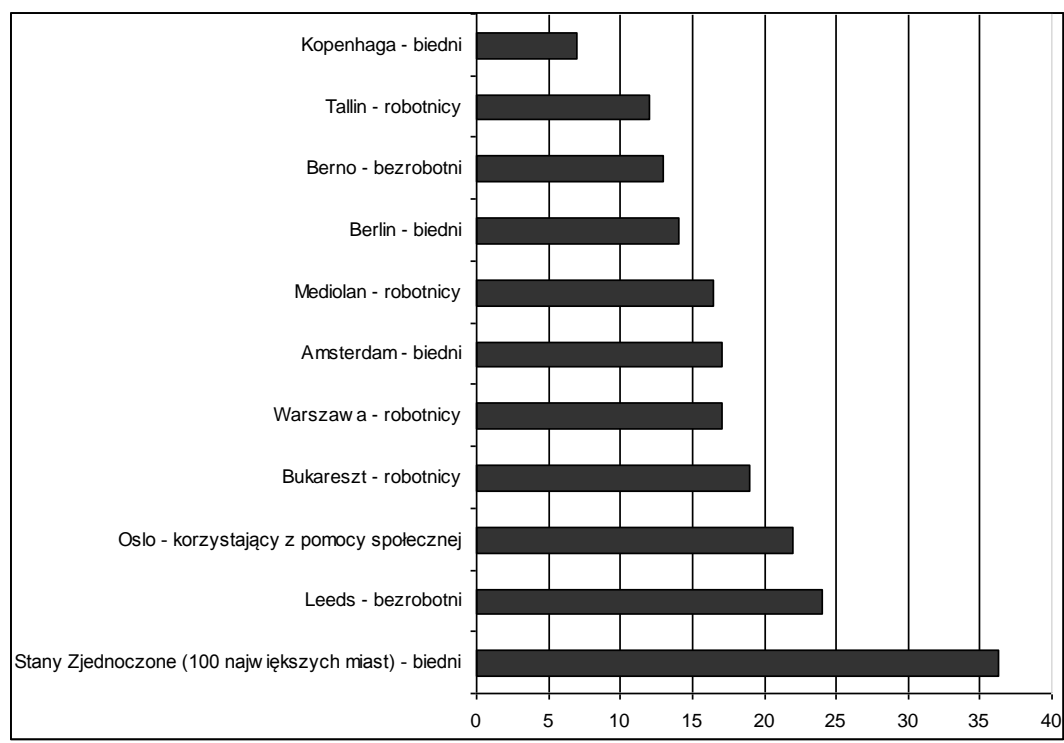

Rysunek 13: Indeksy segregacji dla niższych kategorii społecznych w wielkich miastach Europy i Stanów Zjednoczonych na przełomie XX i XXI wieku Źródło: Opracowanie własne na podstawie: Musterd (2005), spisy powszechne z Rumunii (2002), Polski (2002), Estonii (2000)

Wyniki pracy rzucają także nowe światło na zróżnicowania w poziomie i geografii segregacji społecznej w spektrum miast postsocjalistycznych. Najbardziej zaskakująca, w świetle proponowanych koncepcji teoretycznych i przyjętej na ich podstawie hipotezy, jest kolejność trzech postsocjalistycznych metropolii, biorąc pod uwagę ich poziom segregacji - związek pomiędzy skalą nie- 
równości społecznych a poziomem segregacji społeczno-przestrzennej jest odwrotny od założonego. Dla przypomnienia, na początku XXI wieku Estonia cechowała się najwyższym poziomem nierówności społecznych (wskaźnik Ginniego wynosił 37), na drugim miejscu była Polska (35), a na ostatnim Rumunia (32). Poziom segregacji był natomiast najwyższy w Bukareszcie, a najniższy w Tallinie - zatem nie nawiązywał on do tempa procesu transformacji (w Estonii zmiany następowały decydowanie najszybciej i sięgały najgłębiej, z kolei najwolniej i z największymi oporami transformacja przebiegała w Rumunii).

Opisane powyżej rezultaty pozwalają na dalszą rafinację koncepcji ,paradoksu" segregacji postsocjalistycznej (Sykora 2009, Marcińczak 2012, Marcińczak i inni 2013a, 2013b). Można stwierdzić, że w pierwszej dekadzie przemian systemowych nie tylko brak wyraźnych różnic w poziomie segregacji pomiędzy ośrodkami o zasadniczo odmiennych profilach historyczno-funkcjonalnych przeczy zależnościom głoszonym w literaturze - szybciej rozwijające się miasta postsocjalistyczne nie cechują się znacznie wyższym poziomem segregacji niż te, które doświadczyły załamania gospodarczego po 1990 roku (Marcińczak i inni 2012). Sprzeczność ta cechuje także często braną za pewnik (por. van Kempen 2007) relację pomiędzy poziomem nierówności i skalą segregacji społecznej (rys. 14). Innymi słowy, przykład byłych miast socjalistycznych wskazuje, że szybki wzrost i wysoki poziom nierówności społecznych nie zawsze muszą iść w parze z wyższym poziomem segregacji społecznej.

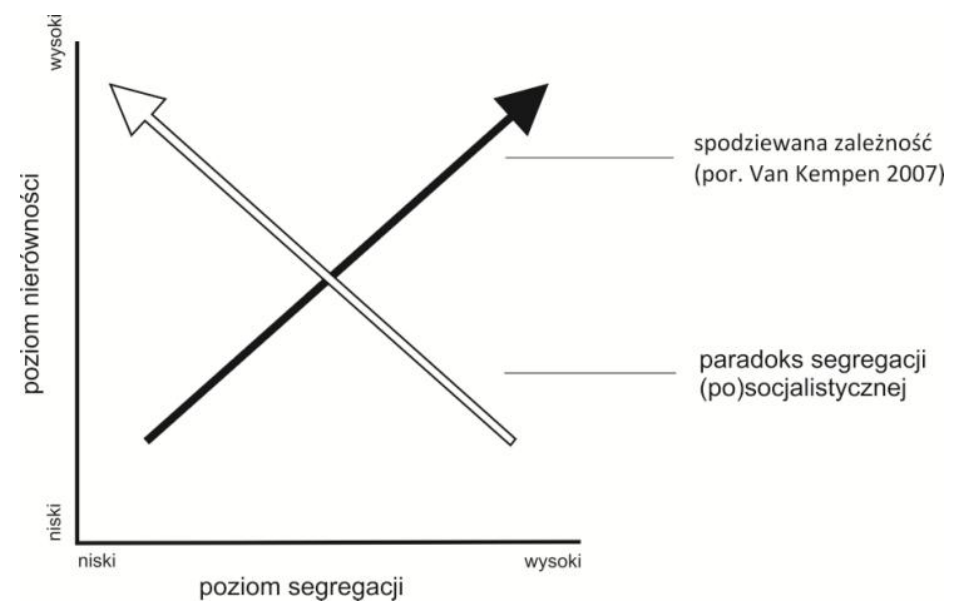

Rysunek 14: Paradoks segregacji (po)socjalistycznej

Źródto: Opracowanie wtasne 
Uwzględnienie w badaniach nad segregacją społeczną podziału miasta postsocjalistycznego na trzy podstawowe strefy/sektory (por. Marcińczak 2009) pozwoliło na dokładniejszy wgląd w naturę zróżnicowań społeczno-przestrzennych. Różnice pomiędzy metropoliami z odmiennych regionów „Europy Wschodniej” dotyczą także różnych trendów w wewnątrzmiejskiej zmienności poziomu segregacji. Zarówno gradient statusu społecznego, jak i zmienność poziomu podziałów spoteczno-przestrzennych, nie pozwalaja na konstrukcje „uniwersalnego" modelu miasta postsocjalistycznego. Schematyczny zapis zmienności statusu społecznego w badanych metropoliach prezentuje rysunek 15 . Już jego pobieżna analiza ujawnia, że sugerowane w literaturze modele zróżnicowań społecznych w mieście postsocjalistycznym (m.in. Kovacs i Herfert 2012) najlepiej opsiują jedynie wielkie miasta Europy Środkowej. Co ciekawe, treść rysunku potwierdza także sugerowaną w literaturze (por. Marcińczak i inni 2013b) zasadniczą różnicę w rozwoju struktur społeczno-przestrzennych miast północy, centrum i południa byłego Bloku Wschodniego.

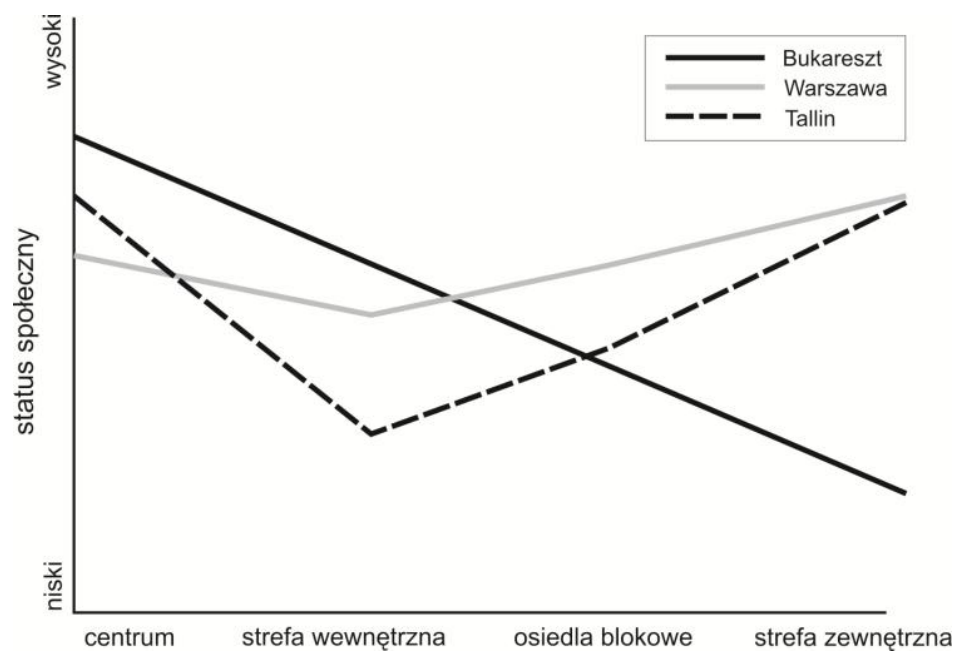

Rysunek 15: Zmiany statusu społecznego z odległością od centrum Bukaresztu, Tallina i Warszawy Źródto: Opracowanie własne

Ostatnim etapem zaproponowanego postępowania badawczego nad wzorami segregacji społeczno-przestrzennej były studia nad geografią tego zjawiska. Ten 
etap analizy segregacji społecznej dostarczył cennych informacji, „ukrytych” $\mathrm{w}$ sumarycznych $\mathrm{z}$ natury indeksach segregacji. Pomimo czytelnych różnic w poziomie tego zjawiska oraz zmienności przestrzennej statusu społecznego mieszkańców, cechą wspólną miast postsocjalistycznych jest mozaikowa struktura podziałów społeczno-przestrzennych. W każdej z badanych metropolii za mozaiką zróżnicowań społeczno-przestrzennych stoi kontekst lokalny, reprezentowany przez dziedzictwo poprzednich faz rozwojowych. W tym miejscu raz jeszcze podkreślić należy stwierdzoną w trzech stolicach swoistą „petryfikację" podziałów społecznych - w okresie socjalistycznym do starych „utrwalonych" wzorów dodawano nowe elementy, a okres posocjalistyczny trwał relatywnie krótko, więc nie wpłynął na zasadnicze ich zmiany.

Dziedzictwo fazy socjalistycznej jest zatem nadal widoczne w nierównomiernym rozmieszczeniu poszczególnych kategorii społecznych w zabudowie o różnym wieku i strukturze własności (Marcińczak i inni 2012). Po upadku systemu wyższe kategorie społeczne wyraźnie podążały za nowymi inwestycjami mieszkaniowymi. Jednak utrzymanie mozaikowości struktury oznacza, że postsocjalistyczne „złote wybrzeża” i „slumsy” są ze sobą wymieszane w przestrzeni każdej z głównych stref i sektorów. Opracowania kartograficzne sporządzone dla głównych kategorii społecznych obrazują, że w każdym z miast występowały jednostki przestrzenne, w których silnie skoncentrowane były grupy społeczne z dwóch krańców hierarchii. W kontekście wzrostu nierówności społecznych, ale też wciąż niezbyt istotnego poziomu segregacji, wydaje się, że odziedziczona po socjalizmie mozaika uległa miejscami wyraźnej fragmentacji. To doprowadzić z kolei mogło do polaryzacji społeczno-przestrzennej w skali bloku urbanistycznego lub budynku.

Jak zatem można wytłumaczyć zarejestrowany poziom i wzory segregacji społecznej w mieście postsocjalistycznym? W świetle współczesnego pojmowania rozwoju regionów miejskich, których los zależy od wyniku interakcji sił globalnych i lokalnego kontekstu (genius loci danego miasta/regionu), obraz podziałów społeczno-przestrzennych po pierwszej dekadzie transformacji zależał od tempa i skali przemian wywołanych zmianą systemu oraz od zastanej struktury społecznej, gospodarczej i przestrzennej. Pamiętać także należy, że pierwsza dekada zmian systemowych kontynuowała trend we wzorach segregacji zapoczątkowany w ostatniej dekadzie socjalizmu (Marcińczak i inni 2013a). Odwołując się do koncepcji „ewolucyjnej” można przyjąć, że stopniowy rozwój procesów gentryfikacji i suburbanizacji doprowadził do „czasowego” wymieszania społeczno-przestrzennego. Początkowa gentryfikacja, ograniczona do jednego lub kilku budynków, prowadzi do „chwilowego” wzrostu heterogeniczności społecznej jednostki przestrzennej, będącej uprzednio miejscem koncen- 
tracji kategorii niższych. Podobny charakter ma rozwój nowych osiedli mieszkaniowych oraz indywidualnej zabudowy jednorodzinnej w strefie zewnętrznej, która w okresie socjalizmu miała niski status społeczny, a gdzie istniały znaczne rezerwy ziemi pod budownictwo.

Pamiętając także o generalnie niskiej mobilności mieszkaniowej społeczeństw miast postsocjalistycznych (Mandić 2001, Marcińczak i Sagan 2011), jak również o upadku budownictwa mieszkaniowego w pierwszej połowie lat 1990. (Ball 2006) oraz powolnym rozwoju rynku kredytów mieszkaniowych (Roy 2006), wzory przestrzenne segregacji społecznej należy w znacznej mierze odczytywać jako obraz inercji struktur społeczno-przestrzennych odziedziczonych po socjalizmie. Zależność ta dotyczy wszystkich grup społecznych, chociaż występują tu pewne różnice pomiędzy kategoriami. Zmiany w krajobrazie społecznym wywołane pierwszą dekadą transformacji wynikają przede wszystkim z mobilności kategorii wyższych. Grupy te znacznie skorzystały na prywatyzacji zasobów mieszkaniowych. Ponadto, po zniesieniu kontroli meldunkowej, stolice zaczęły ściągać migrantów z całego kraju. Potwierdzają to wyniki z największych miast Polski, gdzie udział migrantów w miejscach koncentracji kategorii wyższych często przekraczał 10\% (Marcińczak i inni 2012). Niższe, ale też średnie kategorie społeczne zazwyczaj pozostały lub utknęły w zajmowanych zasobach. Przyczynił się do tego nie tylko stan utrzymania zasobów komunalnych, ale także szybka prywatyzacja mieszkań po bardzo niskich kosztach lub nieodpłatnie. W jej wyniku biedni najemcy stali się biednymi właścicielami mieszkań o niskim standardzie.

Raz jeszcze odwołując się do szybkiego wzrostu nierówności społecznych po 1990 roku, zachodzącego w warunkach małej mobilności mieszkaniowej i powolnego rozwoju budownictwa $\mathrm{w}$ pierwszych latach transformacji, można stwierdzić, że wyniki badań z początku XXI wieku pokazują także zahibernowany potencjał wzrostu poziomu segregacji społecznej w następnych dekadach przemian. Wskazują na to $\mathrm{z}$ jednej strony odziedziczone po socjalizmie braki mieszkaniowe w największych miastach postsocjalistycznych, a z drugiej strony wzrost udziału wyższych i średnich kategorii społecznych wśród ludności aktywnej ekonomicznie, które nie są w stanie spełnić swoich aspiracji mieszkaniowych. Jednak zmiany nabrały większego tempa w drugiej dekadzie transformacji. Szybki rozwój rynku kredytów hipotecznych w pierwszych latach XXI wieku obniżył ich koszt, a gwałtowny rozwój budownictwa w miastach był odpowiedzią ze strony podażowej. Wyjaśnianie statusu prawnego wielu, zwłaszcza śródmiejskich działek także powoli dobiega końca, co wpłynąć może na przyspieszenie przemian $\mathrm{w}$ centralnych obszarach miast - pojawienie się nowej lub zrewitalizowanej tkanki mieszkaniowej na tych terenach stanowi realną alter- 
natywę dla mieszkańców o wyższym statusie społecznym, którzy wciąż mieszkają w blokach.

$\mathrm{Na}$ ile powyższe czynniki wpłynęły i wpłyną na zmiany we wzorach i poziomie segregacji w miastach postsocjalistycznych? Wszystko wskazuje na to, że obraz podzialów spoleczno-przestrzennych zarejestrowany na początku XXI wieku odzwierciedla etap przejściowy, w którym zmiany przestrzenne nie nadążają za zmianami społecznymi. Łatwiej i szybciej przekształceniom podlega struktura społeczna niż struktura przestrzenna miasta. Z czasem przestrzeń jednak ulegnie i nowa forma społeczno-gospodarcza na dobre odciśnie swoje piętno na tkance miasta, a poziom segregacji społecznej z czasem wzrośnie. Tym samym wyniki niniejszego opracowania odczytywać można jako podsumowanie pierwszej dekady najbardziej gwałtownych zmian ustrojowych.

Praca ta, w opinii autora, stanowić może punkt odniesienia dla przyszłych badań nad wzorami segregacji społecznej w miastach byłego bloku wschodniego. Intrygujące byłyby zwłaszcza dalsze studia nad rozwojem i charakterem związków pomiędzy zmianami w poziomie nierówności społecznych i towarzyszącymi im modyfikacjami we wzorach segregacji - innymi słowy odpowiedź na pytania: czy druga dekada po upadku socjalizmu oznacza koniec „paradoksu” segregacji społecznej w „Europie Wschodniej” i czy moment odwrócenia obecnego trendu będzie zależny od położenia miasta w hierarchii osadniczej kraju i regionu byłego Bloku Wschodniego? Interesującymi pozostają także kwestie dotyczące aspektu przestrzennego zachodzących przemian - w jakim kierunku podąży geografia podziałów społecznych w mieście postsocjalistycznym, czy będą to wyraźne i silne podziały w formie stref, znane $\mathrm{z}$ miast amerykańskich, czy utrzymany zostanie bardziej heterogeniczny i mozaikowy model przypisany miastom Europy Zachodniej? I wreszcie, czy zmiany społeczno-przestrzenne w mieście postsocjalistycznym doprowadzą do powstania jednego ogólnego modelu, czy utrzymana zostanie zasygnalizowana w tej pracy specyfika regionalna? Odpowiedzi na te pytania udzielą wyniki kolejnych spisów powszechnych z państw postsocjalistycznych.

Najbardziej oczywista wydaje się kontynuacja badań nad ewolucją poziomu i wzorów podziałów społeczno-przestrzennych. Powinny być one prowadzone przy użyciu globalnych i lokalnych mierników zjawiska, gdyż tylko takie podejście zapewnia pełny obraz wzorów segregacji. Badania $\mathrm{z}$ wykorzystaniem tradycyjnych metod pozwolą zatem monitorować rozwój segregacji, a tym samym mogą pomóc $\mathrm{w}$ formułowaniu polityki społecznej na szczeblu miasta lub regionu miejskiego. Jednak poznanie procesów przyczyniających się do powstawania i ewolucji tych wzorów wymaga zastosowania odmiennych metod. W tym celu należy odwołać się także do zupełnie innego zestawu danych. 
Lepsze poznanie zachowań pojedynczych mieszkańców i gospodarstw domowych, ich decyzji i cech społeczno-demograficznych wpływających na zmianę miejsca zamieszkania, wymaga użycia mikro-danych statystycznych - wyników ankiet lub odpersonalizowanych formularzy spisowych. Pamiętając o relatywnie niskim poziomie segregacji, zastosowanie tego typu danych pomocne będzie także w dokładnym poznaniu segmentacji mieszkaniowej, a więc w udzieleniu odpowiedzi m.in. na pytanie: kto zajmował mieszkania o różnym standardzie, lokalizacji i prawie własności? Jak już wcześniej wspominano, jak do tej pory tematy segmentacji i mobilności mieszkaniowej po socjalizmie należą do niezbyt często podejmowanych w literaturze przedmiotu. Analiza szczegółowych informacji o ludności nie będzie możliwa bez pomocy ze strony zaawansowanych modeli statystycznych. Oferuje ona źródło bezcennych informacji o produkcji i reprodukcji wzorów segregacji, które tracone są w trakcie agregacji danych, nawet dla małych obszarów.

Tematem wartym podjęcia analiz wydaje się być także wpływ działań władz lokalnych w produkcji i reprodukcji enklaw wykluczonych społecznie w zasobach komunalnych. $Z$ drugiej strony należy się także bliżej przyjrzeć stronie podaży, a więc działalności deweloperów, którzy decydują o podjęciu inwestycji w danej lokalizacji, co przekłada się na zmianę społeczno-przestrzenną. Informacje tego rodzaju wydają się być nieodzowne do pełnego zrozumienia złożonego zjawiska, jakim jest segregacja społeczno-mieszkaniowa.

Ostatnią kwestią, która powinna być poważnie rozważona w przyszłych badaniach nad segregacją, jest wielowymiarowość tego zjawiska, a dokładniej fakt, że podziały społeczne manifestowane są także w innych domenach życia niż tylko miejsce zamieszkania. Studiów nad zróżnicowaniem społeczno-przestrzennym wymagają zatem także miejsca pracy, rekreacji, itp. Podsumowując, niniejsza praca stanowi pierwszy krok w poznaniu jakże interesującego zjawiska, jakim jest manifestacja przestrzenna podziałów społecznych, która odbywa się na naszych oczach i z naszym udziałem od ponad dwóch dekad. 


\section{Piśmiennictwo}

Aidukaite J., 2009, Old Welfare state theories and new welfare regimes in Eastern Europe: Challenges and Implications, Communist and Post-communist Studies, 42(1), 23-39

Aidukaite J., 2011, Welfare reforms and socio-economic trends in the 10 new EU member states of Central and Eastern Europe, Communist and Post-communist Studies, 44(2), 211-219

Allen J., Barlow J., Leal J., Maloutas T., Padovani L. (red) (2008) Housing and Welfare in Southern Europe, Blackwell Publishing Ltd, Oxford, UK. doi: 10.1002/9780470757536.fmatter

Altrock U., Gunter S., Huning S., Peters D. (red.), 2007, Spatial Planning and Urban Development in The New EU Member States: From Adjustment to Reinvention, Ashgate, Chippenham

Amin A., Graham S., 1997, The ordinary city, Transitions, Institute of British Geographers, 22, 411-429

Andersson R., 2006 'Breaking segregation' - Rhetorical construct or effective policy? The case of the metropolitan development initiative in Sweden, Urban Studies, 43, 787-799

Andrusz G., 1984, Housing and Urban Development in the USSR, SUNY Press, Albany

Arapoglou V.P., Sayas J., 2009, New facets of urban segregation in southern Europe: Gender, migration and social class change in Athens, European Urban and Regional Studies, 16, 345-362

Arbaci S., 2007, Ethnic Segregation, Housing Systems and Welfare Regimes in Europe, International Journal of Housing Policy, 7(14), 401-433

Åslund A., 2002, Building Capitalism, Cambridge University Press, Cambridge

Badyina A., Golubchikov O., 2005, Gentrification in Central Moscow a market process or a deliberate policy? Money, power and people in housing regeneration in Ostozhenka, Geografiska Annaler, 87B, 113-129

Ball M., 2006, Markets and Institutions in Real Estate and Construction, Blackwell, Oxford

Bandelj N., Mahutga M.C., 2010, How socio-economic change shapes income inequality in post-socialist Europe, Social Forces, 88, 2133-2162 
Basista A., 2001, Betonowe dziedzictwo. Architektura w Polsce w czasach komunizmu, PWN, Warszawa-Kraków

Bater J., 1989, The Soviet scene: a geographical perspective, Edward Arnold, Londyn

Bater, J., 1980, The Soviet City, Edward Arnold, Londyn

Behr E., 1991, Kiss the hand you cannot bite: the rise and fall of Ceausescu, Villard Books, Nowy York

Bell W., 1954, A probability model for the measuring of ecological segregation, Social Forces, 32(4), 357-364

Berend I.T., 2007, Social shock in transforming Central and Eastern Europe, Communist and Postcommunist Studies, 40(3), 269-280

Bernt M., 2009, Partnerships for Demolition: The Governance of Urban Renewal in East. Germany's Shrinking Cities, International Journal of Urban and Regional Research, 33(3), 754-769

Bhalla A. S., Lapeyre F., 2004, Poverty and Exclusion in a Global Word, Macmillan, Gordonsville

Blacksell M., Born K.M., 2002, Private property restitution: the geographical consequence of official government policies in Central and Eastern Europe, The Geographical Journal, 168(2), 178-190

Blinnikov M., Shanin A., Sobolev N., Volkova L., 2006, Gated communities of the Moscow green belt: newly segregated landscapes and the suburban Russian environment, Geojournal, 66, 65-81

Boal F. W., 1999, From undivided cities to undivided cities: assimilation to ethnic cleansing, Housing Studies, 14(5), 585-600

Bodnár J., 1996, 'He That Hath to Him Shall be Given': Housing Privatization in Budapest after State Socialism, International Journal of Urban and Regional Research, 20(4), 616-636

Bodnár J., Böröcz J., 1998, Housing advantages for the better connected? Institutional segmentation, settlement type and social network effects in Hungary's late state socialist housing inequalities, Social Forces, 76 (4), 1275-1304

Booth C., 1887, The Inhabitants of Tower Hamlets (School Bard Division), their conditions and occupations, Journal of the Royal Statistical Society, 50(2), 326-391 
Booth C., 1888, Conditions and Occupations of the People in East London and Hackney, Journal of the Royal Statistical Society, 51(2), 276-331

Borén T., Gentile M., 2007, Metropolitan Processes in Post-Communist States: An Introduction, Geografiska Annaler, 89B, 95-110

Bouzarovski S., Salukvadze J., Gentile M., 2011, A Socially Resilient Urban Transition? The Contested Landscapes of Apartment Building Extensions in Two Post-communist Cities, Urban Studies, 48, 2689-2714

Brade I., Herfert G., Wiest K., 2009, Recent trends and future prospects of socio-spatial differentiation in urban regions of central and eastern Europe: a lull before the storm?, Cities, 26 (5), 233-244

Bradshaw M., Stenning A., (red.), 2004, East Central Europe and the Former Soviet Union: The Post Socialist States, Pearson/Prentice Hall, Harlow

Bråmå Å., 2008, Dynamics of ethnic residential segregation in Göteborg, Sweden, 1995-2000, Population, Space and Place, 14, 101-117

Brown L.A., Chung S.Y., 2006, Spatial segregation, segregation indices and the geographical perspective, Population Space and Place, 12, 125-143

Brown L.A., Moore E.G., 1970, The Intra-urban Migration Process: A Perspective, Geografiska Annaler, 52B, 1-15

Brzeziński M., Kostro K, 2010, Income and consumption inequality in Poland, 1998-2008, Bank i kredyt, 41(4), 45-72

Buckley C., 1995, The myth of managed migration: Migration control and market in the Soviet period, Slavic Review, 54 (4), 896-916

Burgers J., Musterd S., 2002, Understanding urban inequality: a model based on existing theories and an empirical illustration, International Journal of Urban and Regional Research, 26 (2), 403-413

Butler T., Hamnett C., Ramsed M., 2008, Inward and Upward: Marking Out Social Class Change in London, 1981-2001, Urban Studies, 45(1), 67-88

Carter F.W., 1979, Prague and Sofia: An Analysis of Their Changing Internal City Structure [w:] French R.A., Hamilton F. E. I. (red.), The Socialist City: Spatial Structure and Urban Policy, John Wiley \& Sons, Chichester, 425-460

Carter F.W., Maik W. (red.), 1999, Shock-Shift in an enlarged Europe: the geography of socio-economic change in East-Central Europe after 1989, Ashgate, Aldershot-Brookfield-Singapore-Sydney. 
Castells M., 1989, The Informational City, Blackwell, Oxford

Cavalcanti M., 1997, Urban reconstruction and autocratic regimes: Ceausescu's Bucharest in its historic context, Planning Perspectives, 12, 71-109

Cerami A., 2006, Social Policy in Central and Eastern Europe. The emergency of a new European Welfare State, LIT Verlag, Berlin

Cerami A., 2010, The Politics of Social Security Reforms in the Czech Republic, Hungary, Poland and Slovakia [w:] Palier B. (red.), Long Goodbye to Bismarck? The Politics of Welfare Reform in Continental Europe, Amsterdam University Press, Amsterdam

Chelcea L., 2006, Marginal groups in Central Places: Gentrification, Property Rights and Post-Socialist Primitive Accumulation (Bucharest, Romania) [w:] Enyédi G., Kovács Z. (red.), Social Changes and Social Sustainability in Historical Urban Centres: The Case of Central Europe, Hungarian Academy of Science, Pécs

Chelcea L., 2012, The 'Housing Question' and the State Socialist Answer: City, Class and State Remaking in the 1950s Bucharest, International Journal of Urban and Regional Research, 36 (2), 281-296

Chung S.Y., Brown L.A., 2007, Racial/Ethnic Residential Sorting in Spatial Context: Testing the Explanatory Frameworks, Urban Geography, 28(4), 312-339

Church G., 1979, Bucharest: Revolution in the Townscape Art [w:] French R. A., Hamilton F. E. I. (red.), The Socialist City: Spatial Structure and Urban Policy, John Wiley \& Sons, Chichester, 493-506

Ciechocińska M., 1987, Government interventions to balance housing supply and population growth: The case of Warsaw, International Journal of Urban and Regional Research, 11, 9-26

Clark W. A. V., Dieleman F. M., 1996, Households and Housing: Choice and Outcomes in the Housing Market, Center for Urban Policy Research, New Brunswick

Cook A., 2010, The expatriate real estate complex: Creative destruction and the production of luxury in post-socialist Prague, International Journal of Urban and Regional Research, 34, 611-628

Dangschat J., 1987a, Residential Segregation in Warsaw in 1970 and 1978 [w:] Ciechocinska M., Strubelt W., (red.), Determinants of Urban Deve- 
lopment. Urban Research in Poland and West Germany, BfLR Symposien, Heft 26, Bonn, 259-275

Dangschat J., 1987b, Sociospatial disparities in a 'socialist' city: the case of Warsaw at the end of the 1970s. International Journal of Urban and Regional Studies, 11(1), 37-60

Danta D., 1993, Ceausescu’s Bucharest, Geographical Review, 83(2), 170-182

Dawidson K., 2004, Redistributing Nationalized Housing: Impacts on Property Patterns in Timişoara, Romania, Eurasian Geography and Economics, 45(2), 134-156

Deacon B., 2000, Social Policy in Eastern Europe: The Impact of Political Globalisation, Journal of European Social Policy, 10(2), 146-161

Deda L., Tsenkova S., 2006, Poverty and Inequality in Greater Tirana: The Reality of Peri-urban Areas [w:] Tsenkova S., Nedović-Budić Z. (red.), The Urban Mosaic of Post-socialist Europe, Physica verlag., Heidelberg, 151-172

Demko G. J, Regulska J., 1987, Socialism and its impact on urban processes and the city, Urban Geography, 8, 289-292

Domański B., 1997, Industrial Control over the Socialist Town-Benevolence or Exploitation? Westport, CT, Praeger

Domański H., 2004, Struktura spoteczna, Wyd. Naukowe Scholar, Warszawa

Duncan O. T., Duncan B., 1955, A methodological analysis of segregation indexes, American Sociological Review, 20(2), 210-217

Dunford M., Smith A., 2000, Catching up or falling behind? Economic perfomance and regional trajectories in the 'new' Europe, Economic Geography, 76, 169-195

Ellis M., Wright R., Parks V., 2004, Work together, live apart? Geographies of racial and ethnic segregation at home and at work, Annals of the Association of American Geographers, 94, 620-637

Enyédi G., 1994, The transition of post-socialist cities, European Review, 3(2), 171-182

Esping-Andersen G., 1990, The Three Worlds of Welfare Capitalism, Polity Press, Cambridge

Eurostat, http://epp.eurostat.ec.europa.eu/portal/page/portal/statistics/themes 
Feldman M., 2000, Waterfront Revitalization and Local Governance in Tallinn, Estonia, Europe-Asia Studies, 52(5), 829-850

Fitzpatrick S., 2012, Życie codzienne pod rzadami Stalina, Wydawnictwo Uniwersytetu Jagiellońskiego, Kraków

Florida R., 2002, The rise of the Creative Class, Basic Books, Nowy York

Freeman L., 2009, Neighborhood diversity, metropolitan segregation and gentrification: What are the links in the US?, Urban Studies, 26(10), 2079-2101

French R. A., 1995, Plans, Pragmatism and People, UCL Press, Londyn

French R. A., Hamilton, F. E. I. (red.), 1979, The socialist city, Spatial structure and urban policy, John Wiley \& Sons, Chichester

Fuchs R. J., Demko G. J., 1979, Geographic inequality under socialism, Annals of the Association of American Geographers, 69, 304-318

Gabányi A., 2004, The new business elite: from Nomenklatura to Oligarchy [w:] Carem H. (red.), Romania since 1989: Politics, Economics and Society, Lexington Books, Oxford, 353-372

Gaddy C., 1996, The Price of the Past - Russia's Struggle with the Legacy of a Militarized Economy, Brookings Institution Press, Washington DC

Gądecki J., 2009, Za murami. Osiedla grodzone w Polsce - analiza dyskursu, Monografie FNP, Warszawa

Gentile M., Sjöberg Ö., 2010a, Spaces of Priority: The Geography of Soviet Housing Construction in Daugavpils, Latvia, Annals of the Association of American Geographers, 100(1), 1-25

Gentile M., Sjöberg Ö., 2010b, Soviet Housing: Who Built What and When? The Case of Daugavpils, Latvia, Journal of Historical Geography, 36(4), 453-465

Gentile M., Tammaru T., 2006, Housing and Ethnicity in the Post-Soviet City: Ust'-Kamenogorsk, Kazakhstan, Urban Studies, 43(10), 1757-1778

Gentile M., Tammaru T., van Kempen R., 2012, Heteropolitanization: social and spatial change in Central and Eastern Europe, Cities, 29(5), 291-299

Glaeser E., 2011, Triumph of the City, Penguin, New York

Glass R., 1964, London: Aspects of Change, Centre for Urban Studies, MacKibbon and Kee, Londyn 
Grabkowska M., 2011, Inner-city Transformations After Socialism. Findings from Interviews with Residents of Pre-war Tenement Houses in Gdańsk, Bulletin of Geography, Socio-economic Series, 15, 117-129

Grabkowska M., 2012, Regeneration of the Post-Socialist Inner-City: Social Change and Bottom-up Transformation in Gdańsk, Pracownia, Gdańsk

Granis R., 2002, Discussion: Segregation indices and their functional inputs, Sociological Methodology, 32, 69-84

Grime K., 1999, The role of privatisation in post socialist urban transition: Budapest, Kraków, Prague and Warsaw, GeoJournal, 39, 35-42

Grotowska-Leder J., 2000, Współczesna rzeczywistość, współczesna bieda (wybrane teoretyczne i empiryczne podstawy analizy biedy), Przegląd Socjologiczny, 69(1), 31-58

Grzeszczak J., 2010, Gentryfikacja osadnictwa: charakterystyka, rozwój koncepcji badawczych i przegląd wyjaśnień, Monografie IGiPZ PAN, 11

Halleux J.M., Marcinczak S., van der Krabben E., 2012, The adaptive efficiency of land use planning measured by the control of urban sprawl. The cases of the Netherlands, Belgium and Poland, Land Use Policy, 29(4), 887-898

Halloway S. R., Wright R., Ellis M., 2012, The Racially Fragmented City? Neighborhood Racial Segregation and Diversity Jointly Considered, The Professional Geographer, 64(1), 63-82

Hamilton F. E. I., Andrews K., Pichler-Milanović N. (red.), 2005, Transformation of Cities in Central and Eastern Europe: Towards Globalization, United Nations University Press, Tokyo

Hamilton F. E. I., Burnett A. D., 1979, Social Processes and Residential Structure [w:] French R. A., Hamilton F. E. I. (red.), The Socialist City: Spatial Structure and Urban Policy, John Wiley \& Sons, Chichester, 263-304

Hamnett C., 1994, Social Polarization in Global Cities: Theory and Evidence, Urban Studies, 31(3), 401-424

Hamnett C., 1998, Social Polarisation, Economic Restructuring and Welfare State Regimes [w:] Musterd S., Ostendorf W., Urban Segregation and the Welfare State, Routledge, Nowy York-Londyn, 15-27

Hamnett C., 2001, Social segregation and social polarization [w:] Paddison R. (red.), Handbook of Urban Studies, Sage, Londyn 
Harloe M., 1996, Cities in transition [w:] Andrusz G., Harloe M., Szelényi I., (red.) Cities after Socialism. Urban and Regional Change and Conflict in Post-Socialist Societies, Blackwell, Oxford, 1-29

Harvey D., 1973 (2009), Social Justice and the City, The University of Georgia Press, Athens

Hegedüs J., Tosics I., 1996, Disintegration of East-European Housing Model [w:] Clapham D., Hegedüs J., Kintrea K., Tosics I. (red.), Housing Privatization in Eastern Europe, Greenwood Press, Londyn

Heyns B., 2005, Emerging inequalities in Central and Eastern Europe, Annual Review of Sociology, 31, 163-197

Hirt S., 2007, Suburbanizing Sofia: Characteristics of post-socialist peri-urban change, Urban Geography, 28(8), 755-780

Hirt S., 2012, Iron Curtains: Gates, Suburbs and privatization of Space in the Post-socialist city, John Wiley \& Sons, Londyn

Hörschelmann K., 2004, The social consequences of transformation [w:] Bradshaw M., Stenning A. (red.), East Central Europe and the Former Soviet Union: The Post Socialist States, Pearson/Prentice Hall, Harlow, 219-246

Index Mundi 2013 - międzynarodowe dane statystyczne o społeczeństwie i gospodarce dostępne online na: http://www.indexmundi.com/

ISCO - międzynarodowa klasyfikacja zawodów, dostępna online na: http://epp.eurostat.ec.europa.eu/portal/page/portal/income_social_inclusion_ living_conditions/documents/tab/Tab/ISCO\%202011.pdf

Jadach-Sepioło A., 2007, Gentryfikacja Miast, Problemy Rozwoju Miast, 3.

Jahn J. A., Schmid C. F., Schrag I. C., 1948, The measurement of ecological segregation, American Sociological Review, 27(3), 293-303

Jakóbczyk-Gryszkiewcz J., Marcińczak S., Siejkowska A., 2010, Dynamika i skutki procesów urbanizacji w regionach miejskich po 1990 roku na przykładzie regionu miejskiego Lodzi, Wydawnictwo Uniwersytetu Łódzkiego, Łódź

Jałowiecki B., 2000, Społeczna przestrzeń metropolii, Scholar, Warszawa

Johnston R. J., Jones K., 2010, Commentary, Environment and Planning A, 42, 1264-1270 
Johnston R. J., Poulsen M., Forrest J., 2002, Rethinking the analysis of ethnic residential patterns: Segregation, isolation or concentration thresholds in Auckland, New Zealand, Geographical Analysis, 34, 245-261

Johnston R. J., Poulsen M., Forrest J., 2005, On the measurement and meaning of residential segregation: A reply to Simpson, Urban Studies, 42, 1221-1227

Johnston R. J., Poulsen M., Forrest J., 2007, Ethnic and residential segregation in U.S. metropolitan areas, 1980-2000: the dimensions of segregation revisited, Urban Affairs Review, 42(4), 479-504

Johnston R. J., Poulsen M., Forrest J., 2007, The geography of ethnic residential segregation: A comparative study of five countries, Annals of the Association of American Geographers, 97(4), 713-738

Johnston R. J., Poulsen M., Forrest J., 2010, Moving On from Indices, Refocusing on Mix: On Measuring and Understanding Ethnic Patterns of Residential Segregation, Journal of Ethnic and Migration Studies, 36(4), 697-706

Johnston R. J., Poulsen M., Forrest J., 2011, Evaluating Changing Residential Segregation in Auckland, New Zealand, Using Spatial Statistics, Tijdschrift voor Economische en Sociale Geografie, 102(1), 1-23

Johnston, R. J., Poulsen M., Forrest J., 2009, Research Note - Measuring Ethnic Residential Segregation: Putting some more geography in, Urban Geography, 30(1), 91-109

Kabisch S., Sagan I., The Inner City In Focus [w:] Haase A., Steinführer A., Kabisch S., Grossmann K., Hall R. (red.), Residential Change and Demographic Challenge. The Inner City of East Central Europe in the $21^{\text {st }}$ Century, Ashgate, Londyn, 85-99

Kaczmarek S., Marcińczak S., 2013, The Blessing in Disguise: Urban Re-generation in Poland in a Neo-liberal Milieu [w:] Leary M. E., McCarthy J. (red.), The Routledge Companion to Urban Regeneration, Routledge, Londyn

Kaczmarek S., 2004, Sprawiedliwość społeczna w przestrzeni a warunki życia w mieście [w:] Jażdżewska I. (red.), Zróżnicowanie warunków życia ludności w mieście, XVII Konwersatorium Wiedzy o Mieście, Wydawnictwo Uniwersytetu Łódzkiego, Łódź, 31-39

Kährik A., Tammaru T., 2010, Soviet prefabricated panel housing estates: Areas of continued social mix or decline? The case of Tallinn, Housing Studies, 25, 201-219 
Kiss E., 2002, Restructuring in the industrial areas of Budapest in the period of transition, Urban Studies, 39(1), 69-84

Kok H., Kovács Z., 1999, The process of suburbanization in the agglomeration of Budapest, Netherlands Journal of Housing and the Built Environment, 14(2), 119-141

Kornai J., 1992, The Socialist System: The political economy of socialism, Princeton University Press, Princeton

Kostreš M., Reba D., 2010, Housing for the new socio-economic elite: the case of Novi Sad, Architecture and Civil Engineering, 8(3), 329-343

Kovács Z., Wiessner R., Zischner R., 2012, Urban Renewal in the Inner City of Budapest: Gentrification from a Post-socialist Perspective, Urban Studies, dostęp online: doi:10.1177/0042098012453856

Kovács Z., 1998, Ghettoisation or Gentrification? Post-socialist Scenarios for Budapest, Netherlands Journal of Housing and the Built Environment, 13(1), 63-81

Kovács Z., 2009, Social and economic transformation of historical neighborhoods in Budapest, Tijdschrift voor Economische en Sociale Geografie, 100, 399-416

Kovács Z., Herfert, G., 2012, Development Pathways of Large Housing Estates in Post-socialist Cities: An International Comparison, Housing Studies, 27(3), s. 324-342

Kowalski M., Śleszyński P., 2006, Problems of socio-spatial development in central districts of Warsaw [w:] Enyédi G., Kovács Z. (red.), Social Changes and Social Sustainability in Historical Urban Centers: The Case of Central Europe, Hungarian Academy of Sciences, Pécs, 107-126

Krupka D., 2007, Are Big Cities More Segregated? Neighborhood Scale and the Measurement of Segregation, Urban Studies, 44(1), 187-197

Kulu, H., 2003, Housing differentiation in the late Soviet city: the case of Tartu, Estonia, International Journal of Urban and Regional Research, 27(4), 897-911

Ladányi J., 1989, Changing patterns of residential segregation in Budapest, International Journal of Urban and Regional Research, 13(4), 555-571

Leetmaa K., Tammaru T., 2007, Suburbanisation in Countries in Transition: Destinations of Suburbanizers in the Tallinn Metropolitan Area, Geografiska Annaler, 89B(2), 127-146 
Leetmaa K., Tammaru T., Anniste K., 2009, From priority-led to market-led suburbanisation in a post-communist metropolis, Tijdschrift voor economische en sociale geografie, 100(4), 436-453

Liberson S., 1981, An asymmetrical approach to segregation [w:] Peach C., Robinson V., Smith S., Croom Helm, Londyn

Lis P., 2012, Wahania cykliczne rynków mieszkaniowych. Aspekty teoretyczne i praktyczne, Wydawnictwo Adam Marszałek, Toruń

Lisowski A., 2000, Dualne miasto - metafora a rzeczywistość, Przegląd Geograficzny, 72(3), 231-247

Liszewski S., Marcińczak S., 2012, Geografia gentryfikacji Łodzi: studium dużego miasta przemysłowego w okresie posocjalistycznym [w:] JakóbczykGryszkiewicz J. (red.), Procesy gentryfikacji w mieście, Wydawnictwo UŁ, Łódź, 71-88

Liszewski S., 2004, Przemiany struktury przestrzennej aglomeracji przemysłowej $w$ okresie transformacji ustrojowej (przykład łódzkiej aglomeracji miejskiej) [w:] Słodczyk J. (red.), Przemiany struktury przestrzennej miast w sferze funkcjonalnej i społecznej, Uniwersytet Opolski, Opole, 9-25

Liszewski S. (red.), 2012, Geografia urbanistyczna, Wyd. II, PWN, Warszawa

Lux M., Sunega P., 2010, The future of housing systems after the transitionThe case of the Czech Republic, Communist and Post-Communist Studies, $43,221-231$

Maik W., 1998, Metodologia polskiej geografii osadnictwa [w:] Kaczmarek J. (red.), X Konwersatorium wiedzy o mieście, ŁTN, Łódź, s.7-14

Maik W., 2003, Pojęcie metropolii a problem badania funkcji metropolitalnych [w:] Jażdżewska I., (red.) Funkcje metropolitalne $i$ ich rola $w$ organizacji przestrzeni, XVI Konwersatorium Wiedzy o Mieście, Wydawnictwo ŁTN, Łódź

Maik W., 2007, Pluralizm problemowy, metodologiczny $i$ teoretyczny jako perspektywa geografii miast XXI wieku [w:] Jażdżewska I. (red.), Polska geografia osadnictwa. Dotychczasowy dorobek. Program badań, XX Konwersatorium Wiedzy o Mieście, Wydawnictwo Uniwersytetu Łódzkiego, Łódź, 291-302

Maik W., 2012, Podstawy teoretyczno-metodologiczne studiów geograficznomiejskich. Studium z metodologii miast, Wydawnictwo WSG, Bydgoszcz 
Malheiros J., 2002, Ethni-cities: Residential patterns in the northern European and Mediterranean metropolises - Implications for policy design, International Journal of Population Geography, 8, 107-134

Mandič, S., 2001, Residential mobility versus 'in-place' adjustments in Slovenia: viewpoint from a society 'in transition', Housing Studies, 16(1), 53-73

Marcińczak S., 2009, Przemiany struktury społeczno-przestrzennej Łodzi w latach 1988-2005, Wydawnictwo UŁ, Łódź

Marcińczak S., 2011, From totalitarian land-regulation to domination of property rights: the evolution of strategic spatial planning in Poland after socialism [w:] Tira M., van der Krabben E., Zanon B. (red.), Land Managment for Urban Dynamics. Innovative methods and practices in a changing Europe, Maggioli, Mediolan, 179-192

Marcińczak S., 2012, The evolution of spatial patterns of residential segregation in Central European Cities: The Lódź Functional Urban Region from mature socialism to mature post-socialism, Cities, 29(5), 300-309

Marcińczak S., Gentile M., Stępniak M., 2013a, Paradoxes of (post)socialist segregation: metropolitan sociospatial divisions under socialism and after in Poland, Urban Geography, w druku

Marcińczak S., Gentile M., Rufat S., Chelcea L., 2013b, Urban geographies of hesitant transition: tracing socio-economic segregation in post-Ceauşescu Bucharest, International Journal of Urban and Regional Research, w druku

Marcińczak S., Musterd S., Stępniak M., 2012, Where the grass is greener: social segregation in three major Polish cities at the beginning of the $21^{\text {st }}$ century, European Urban and Regional Studies, 19(4), 383-403

Marcińczak S., Sagan I., 2011, The socio-spatial restructuring of Łódź, Poland, Urban Studies, 48(9), 1789-1809

Marcuse P., 1989, 'Dual city': a muddy metaphor for a quartered city, International Journal of Urban and Regional Research, 13(4), 697-708

Marcuse P., van Kempen R. (red.), 2009, Globalizing Cities, a new spatial order?, Blackwell Publisher

Marek L., 2011, Gini index in the Czech Republic in 1995-2010, Statistika, $48(2), 42-48$ 
Marin V., 2005, Inhabiting the Outskirts of Bucharest "Old" Socialist Housing Estates versus "New" Capitalist Suburbia Developments [w:] Eckardt F. (red.), Paths of Urban Transformation, Peter Lang verlag, Frankfurt, 121-142

Marszał T., 1999, Zróżnicowanie i kierunki rozwoju budownictwa mieszkaniowego w Polsce [w:] Marszał T. (red.), Budownictwo mieszkaniowe $w$ latach 90. - zróżnicowanie przestrzenne i kierunki rozwoju, Biuletyn KPZK PAN, 190, Warszawa, 7-27

Massey D. S., Denton N. A., 1988, The Dimensions of Residential Segregation, Social Forces, 67(2), 281-315

Massey D. S., Denton N. A., 1993, American Apartheid: Segregation and the Making of the Underclass, Harvard University Press, Cambridge

Matejů P., Večerník J., 1981, Social Structure, Spatial Structure and Problems of Ecological Analysis: The Example of Prague [w:] Harloe M., Lebas E. (red.), City, Class and Capital - New Developments in the Political Economy of Cities and Regions, Edward Arnold, Londyn

Miliutin N. A., 1974, Sotsgorod. The Problem of Building Socialist Cities, The MIT Press, Londyn

Mionel V., Neguţ S., 2011, The social dimension of the Bucharest ghettos. Transylvanian Review of Administrative Sciences, 33, 197-217

Mollenkopf J. H., Castells M. (red.), 1991, Dual city. Restructuring New York, SAGE, Nowy York

Morgan B. S., 1975, The Segregation of Socio- economic Groups in Urban. Areas: a Comparative. Analysis, Urban Studies 12(1), 47-60

Morton R. W., 1984, The Contemporary Soviet City [w:] Morton H. W., Stuart R. C. (red.), The Contemporary Soviet City, M.E. Sharpe, Nowy York, 3-24

Murdie R., Borgegård L. E., 1998, Immigration, spatial segregation and housing segregation of immigrants in metropolitan Stockholm 1960-95, Urban Studies, 35, 1869-1888

Murie A., 1997, The Social Rented Sector. Housing and the Welfare State in the UK, Housing Studies, 12(3), 437-461

Murie A., 2009, The Modernisation of Housing in England. Tijdschrift voor Economische en Sociale Geografie, 100(4), 535-548 
Murray P., Szelényi I., 1984, The city in the transition to socialism, International Journal of Urban and Regional Research, 8(1), 90-107

Murzyn M., 2006, "Winners" and "losers" in the game: the social dimension of urban regeneration in the Kazimierz quarter in Krakow [w:] Enyédi G., Kovács Z. (red.), Social changes and social sustainability in historical urban centres. The case of Central Europe, Hungarian Academy of Sciences and Centre for Regional Studies, 81-106

Musterd S., Deurloo R., 1997, Ethnic segregation and the role of public housing in Amsterdam, Tijdschrift voor Economische en Sociale Geografie, $88,158-168$

Musterd S., 2005, Social and Ethnic Segregation in Europe: Levels, Causes, and Effects, Journal of Urban Affairs, 27(3), 27-36

Musterd S., Murie A., 2010, Synthesis: Re-making the competitive city, [w:] Musterd S., Murie A. (red.), Making Competitive Cities, Wiley Blackwell, Oxford, 327-350

Musterd S., Ostendorf W., 1998, Urban Segregation and the Welfare State, Routledge, Nowy York-Londyn

Musterd S., Ostendorf W., 2012, Social Mix in Western Countries [w:] Smith S. J., Elsinga M., O’Mahony L. F., Eng O. S., Wachter S., Hamnett C., (red.), International Encyclopedia of Housing and Home, 6, Elsevier, Oxford, 469-472

Musterd S., Ostendorf W., 2012b, Inequalities in European Cities [w:] Smith S. J., Elsinga M., O’Mahony L. F., Eng O. S., Wachter S., Clapham D. (red.), International Encyclopedia of Housing and Home, 4, Elsevier, Oxford, 49-55

Musterd S., van Kempen R., 2009, Segregation and Housing of Minority Ethnic Groups in Western European Cities, Tijdschrift voor Economische en Sociale Geografie, 100(4), 559-566

Nae M., Turnock D., 2011, The New Bucharest. Two Decades of Restructuring, Cities, 28, 206-219

Nightingale C. H., 2012, Segregation: a global history of divided city, University of Chicago Press, Chicago

North D. C., 1990, Institutions, Institutional Change and the Economic Performance, Cambridge University Press, Cambridge 
Novák J., Sýkora L., 2007, A City in Motion: Time-space Activity and Mobility Patterns of Suburban Inhabitants and Structuration of Spatial Organization of the Prague Metropolitan Area, Geografiska Annaler, B89(2), 147-167

O’Neill B., 2009, The political agency of cityscapes, Journal of Social Archeology, 9(1), 92-109

Ouředniček M., 2007, Differential Suburban Development in the Prague Urban Region, Geografiska Annaler, 89B, 111-126

Pahl R., 1975, Whose City?, Penguin, Harmondsworth

Palier B., (red.), 2010, Long Goodbye to Bismarck? The Politics of Welfare Reform in Continental Europe, Amsterdam University Press, Amsterdam

Park R. E., Burgess E. W., McKenzie R. D. (red.), 1925, The city, Chicago University Press, Chicago

Parysek J. J., 2003, Metropolie: metropolitalne funkcje i struktury przestrzenne [w:] Jażdżewska I. (red.), Funkcje Metropolitalne $i$ ich rola $w$ organizacji przestrzeni, XVI Konwersatorium Wiedzy o Mieście, Wydawnictwo ŁTN, Łódź, 19-40

Pásztor G., Péter L., 2009, Urban housing problem in Romania: The legacy of communist blocks of flats, Studia universitatis Babes-Bolyai, Sociologia, 79-100

Peach C., 2009, Slippery Segregation: Discovering or Manufacturing Ghettos?, Journal of Ethnic and Migration Studies, 35(9), 1381-1395

Petrovici N., 2012, Workers and the City: Rethinking the Geographies of Power in Post-socialist Urbanisation, Urban Studies, 49(11), 2377-2397

Philpott T. L., 1978, The Slum and the Ghetto: Neighborhood Deterioration and Middle-Class Reform, Chicago 1880-1930, Oxford University Press, Nowy York

Pichler-Milanovich N., 1994, The role of housing policy in transformation process in Central-East European cities, Urban Studies, 31, 1097-1115

Pickles J., Smith A., 1998, Theorizing Transition: The Political and Economy of Post-communist Transformations, Routledge, Londyn

Pióro Z., 1962, Ekologia społeczna w urbanistyce (na przykładzie badań lubelskich i toruńskich), Arkady, Warszawa 
Piotrowski W., 1966, Społeczno-przestrzenna struktura m. Łodzi. Studium ekologiczne, Ossolineum, Wrocław

Polanska D., 2011, The emergence of enclaves of wealth and poverty - a sociological study of residential differentiation in post-communist Poland, Stockholm Studies in Sociology, 50, Stockholm University, Stockholm

Poulsen M .F., Johnston R., Forrest J., 2002, Plural Cities and Ethnic Enclave: Introducing a measurement procedure for comparative study, International Journal of Urban and Regional Research, 26(2), 229-243.

Prelogović V., 2009, Primjena faktorske analize u istraživanju socio-prostorne strukture grada: primjer Zagreba, Hrvatski Geografski Glasnik, 71(1), 67-85

Rashid M., Rutkowski J., Fretwell D., 2005, Labor Markets [w:] Barr N. (red.), Labor Markets and Social Policy in Central and Eastern Europe: The Accession and Beyond, World Bank Publications, Hemdon, 59-85

Reardon S. F., 2006, A Conceptual Framework for measuring segregation and its association with population outcomes [w:] Oakes J. M., Kaufman J. S. (red.), Methods in Social Epidemiology, Jossey-Bass, San Francisco, 169-192

Ronnås P., 1984, Urbanization in Romania, The Economics Research Institute at the Stockholm School of Economics, Stockholm

Rosati D. K., 2009, Europejski Model Społeczny. Doświadczenia i Przyszłość, PWE, Warszawa

Rossi P. H., 1955, Why Families Move: A Study in the Social Psychology of Urban Residential Mobility, Free Press, Glencoe

Roy F., 2008, Mortgage markets in central and eastern Europe - A review of past experiences and future perspectives, European Journal of Housing Policy, 8, 133-160

Ruble B., 1989, Ethnicity and Soviet cities, Soviet Studies, 41(3), 401-414

Rufat S., 2013, Spectroscopy of Urban Vulnerability. Annals of the Association of American Geographers, dostęp online:DOI:10.1080/00045608.2012. 702485

Rukavishnikov V. O., 1980, Naselenie goroda (sotsial'nyi sostav, rasselenie, otsenka gorodskoy sredy), Statistika, Moskwa

Ruoppila S., 2004, Processes of Residential Differentiation in Socialist Cities: Literature Review on the Cases of Budapest, Prague, Tallinn and Warsaw, 
European Journal of Spatial Development, 9, dostęp online: http://www. nordregio.se/EJSD/

Ruoppila S., Kährik A., 2003, Socio-economic residential differentiation in post-socialist Tallinn, Journal of Housing and the Built Environment, 18(1), 49-73

Rykiel Z., 1984, Intra-metropolitan migration in the Warsaw agglomeration, Economic Geography, 60, 55-70

Sachs S., 2012, The price of civilization. Reawakening virtue and Prosperity after the economic fall, Vintage, Londyn

Sagan I., 2000, Miasto scena konfliktów i współpracy, Wydawnictwo Uniwersytetu Gdańskiego, Gdańsk

Sailer-Fliege U., 1999, Characteristics of post-socialist urban transformation in East Central Europe, GeoJournal, 49(1), 7-16

Sassen S., 1991, The global city: New York, London, Tokyo, Princeton University Press, Princeton

Schelling T.C., 2006, Micromotives and macrobehavior, WWHorton\&Company, Londyn

Schnell I., Yoav B., 2001, The Sociospatial Isolation of Agents in Everyday Life Spaces as an Aspect of Segregation, The Annals of the American Association of Geographers, 91(4), 622-636

Scott A.J., Storper M., 1986, Production, Work, Territory. The geographical anatomy of industrial capitalism

Scott, A. J., 1988, Metropolis: From the Division of Labour to Urban Form, University of California Press, Los Angeles, Allen\&Unwin, Boston

Sennett R., 2010, Kultura nowego kapitalizmu, Warszawskie Wydawnictwo Literackie MUZA, Warszawa

Shevky E., Bell W., 1955, Social Area Analysis, Stanford University Press, Stanford

Simpson L., 2004, Statistics of racial segregation: Measures, evidence and policy, Urban Studies, 41, 661-681

Simpson L., 2007, Ghettos in the mind: the empirical behavior of indices of segregation and diversity, Journal of the Royal Statistical Society A, $170(2), 405-424$ 
Sin C. H., 2003, The interpretation of segregation indices in context: The case of $P^{*}$ in Singapore, The Professional Geographer, 54, 422-437

Sjöberg Ö., 1991, Urbanisation under central planning: the case of Albania, Acta Universitatis Upsaliensis, Comprehensive Summaries of Uppsala Dissertations from the Faculty of Social Sciences, 23, Uppsala University, Uppsala

Sjöberg Ö., 1994, Rural retention in Albania: administrative restrictions on urban-bound migration, East European Quarterly, 28(2), 205-233

Stownik wspótczesnego języka polskiego, B. Dunaj (red.), 1996, Wydawnictwo Wilga, Warszawa 1996

Śleszyński P., 2004, Ksztaltowanie się zachodniej części centrum Warszawy, Prace Geograficzne, 196, Instytut Geografii i Przestrzennego Zagospodarowania PAN, Warszawa

Smętkowski M., 2009, Zróżnicowania społeczno-przestrzenne Warszawy inercja czy metamorfoza struktury miasta?, Przegląd Geograficzny, 81(4), 461-482.

Smith A., Stenning A., Rochovska A., Świątek D., 2008, The emergence of a working poor: Labor markets, neoliberalisation and diverse economies in post-socialist cities, Antipode, 40, 283-311

Smith D.M., 1989, Urban Inequality under Socialism - case studies from Eastern Europe and the Soviet Union, Cambridge University Press, Cambridge

Smith D. M., 1996, The socialist city [w:] Andrusz G., Harloe M., Szelényi I. (red.), Cities after Socialism. Urban and Regional Change and Conflict in Post-Socialist Societies, Blackwell, Oxford, 70-99

Smith J., Timar J., 2010, Uneven transformations: Space, economy and society 20 years after the collapse of state socialism, European Urban and Regional Studies, 17, 115-125

Soaita A. M., 2012, Strategies for In Situ Home Improvement in Romanian Large Housing Estates, Housing Studies, 12(7), 180-194

Speveć D., Klempić-Bogadi S., 2009, Croatian Cities under Transformation: New Tendencies in Housing and Segregation, Tijdschrift voor Economische en Sociale Geografie, 100(4), 454-468

Stanilov K. (red.), 2007, The Post-Socialist City: Urban Form and Space Transformations in Central and Eastern Europe after Socialism, Springer, Dordrecht 
Steinführer A., Haase A., 2007, Demographic Change as a Future Challenge for Cities in East Central Europe, Geografiska Annaler, Series B, Human Geography, 89(2), 183-195

Stenning A., 2004, Urban change and the localities [w:] Bradshaw M., Stenning A. (red.), East Central Europe and the Former Soviet Union. The post socialist states, Pearson/Prentice Hall, Harlow, 87-108

Stenning A., Smith A., Rochovska A., Świątek D., 2010, Domesticating NeoLiberalism: Spaces of Economic Practice and Social Reproduction in PostSocialist Cities, Wiley-Blackwell, Oxford

Stępniak M., 2012, The Spatial deconcentration of housing resources in Warsaw in the years 1945-2008, Geographia Polonica, 85(1), 67-80

Stępniak M., Węcławowicz G., Górczyńska M., Bierzyński A., 2009, Warszawa w świetle Narodowego Spisu Powszechnego 2002, Atlas Warszawy, 11, IGiPZ PAN, Warszawa

Stoyanov P., Frants K., 2006, Gated communities in Bulgaria: interpreting a new trend in post-communist urban development, Geojournal, 66, 57-63

Suchecki B., Olejnik A., 2010, Miary $i$ testy statystyczne $w$ eksploracyjnej analizie danych przestrzennych [w:] Suchecki B. (red.), Ekonometria Przestrzenna. Metody i modele analizy danych przestrzennych, Wydawnictwo $\mathrm{CH}$ Beck, Warszawa, 100-125

Sýkora L., 1994, Local urban restructuring as a mirror of globalization processes: Prague in the 1990s, Urban Studies, 31(7), 1149-1166

Sýkora L., 1999, Changes in the internal structure of post-communist Prague, Geojournal, 49, 79-89

Sýkora L., 2005, Gentrification in post-communist cities [w:] R. Atkinson R., Bridge G. (red.), Gentrification in Global Context: The New Urban Colonialism, Routledge, Londyn, 90-105

Sýkora L., 2007, The Czech Case Study - Social Inequalities in Urban Areas and Their Relationship with Competitiveness in the Czech Republic [w:] Szirmai V. (red.), Social Inequalities in Urban Areas and Globalisation: The Case of Central Europe

Sýkora L., 2009, New Socio-Spatial Formations: Places of Residential Segregation and Separation in Czechia, Tijdschrift voor Economische en Sociale Geografie, 100, 417-435 
Sýkora L., Bouzarovski S., 2012, Multiple transformations: conceptualising the post-communist urban transition, Urban Studies, 49(1), 43-60

Szelényi I., 1978, Social inequalities in state socialist redistributive economies, International Journal of Comparative Sociology, 63-87

Szelényi I., 1983, Urban Inequalities under State Socialism, Oxford University Press, Nowy York

Szelényi I., 1987, Housing inequalities and occupational segregation in state socialist cities. Commentary to the special issue of IJURR on east European cities, International Journal of Urban and Regional Research, 11, 1-8

Szelényi I., 1996, Cities under socialism and after [w:] Andrusz G., Harloe M., Szelényi I., (red.) Cities after Socialism: Urban and Regional Change and Conflict in Post-Socialist Societies, Blackwell, Oxford, 286-317

Tammaru T., 2001, The Soviet Union as a deviant case? Underurbanization in soviet Estonia, Urban Geography, 22(6), 584-603

Tasan-Kok T., 2007, Istambul, Budapeszt and Warsaw: Institutional and Spatial Change, Eburon, Londyn

Tátrai P., 2011, Ethnic residential segregation in three cities in northwest Romania, Hungarian Geographical Bulletin, 60(2), 189-216

Temelová J., 2007, Flagship developments and the physical upgrading of the post-socialist inner city: The Golden Angel project in Prague, Geografiska Annaler, 89B(2), 169-181

Temelová J., Novák J., Ouředníček M., Puldová P., 2011, Housing estates in the Czech Republic: various trajectories and inner differentiation, Urban Studies, 48(9), 1811-1834

Tosics I., 2005, City development in Central and Eastern Europe since 1990: The impacts of internal forces [w:] Hamilton F. E. I., Andrews K., PichlerMilanović N. (red.), Transformation of Cities in Central and Eastern Europe, United Nations University Press, Tokyo, 44-78

Tsenkova S., 2006, Beyond transitions: Understanding urban change in postsocialist cities [w:] Tsenkova S., Budic-Nedovic Z., (red.) The urban mosaic of post-socialist Europe, Springer, Heidelberg

Tsenkova S., 2008, Managing change: the comeback of post-socialist cities, Urban Research and Practice, 1(3), 291-310 
Turnock D., 1990, Bucharest City Profile, Cities, 7(2), 107-118

Turnock D., 2007, Aspects of Independent Romania's Economic History with Particular Reference to Transition for EU Accession, Ashgate, Aldershot

Van de Kaa D. J., 1987, Europe's Second Demographic Transition, Population Bulletin, 42(1), The Population Reference Bureau, Washington

van Kempen R., 2007, Divided cities in the $21^{\text {st }}$ century: Challenging the importance of globalization, Journal of Housing and Built Environment, 22(1), 13-31

van Kempen R., Murie A., 2009, The New Divided City: Changing Patterns in European Cities, Tijdschrift voor Economische en Sociale Geografie, 100(4), 377-398

Van Kempen R., Özüekren A. S., 1998, Ethnic segregation in cities: new forms and explanations in a dynamic world, Urban Studies, 35(10), 1631-1653

Vendina O., 1997, Transformation processes in Moscow and in intra-urban stratification of population, GeoJournal, 42(4), 349-363

Vöckler K., 2010, Turbo Urbanism in Prishtina [w:] Kliems A., Dmitrieva M. (red.), The Post-Socialist City - Continuity and Change in Urban Imagery, Jovis verlag, Berlin, 210-229

Walmsley D. J., Lewis G. J., 1997, Geografia człowieka. Podejście behawioralne, PWN, Warszawa

Warzywoda-Kruszyńska W., Grotowska-Leder J., 1996, Wielkomiejska bieda w okresie transformacji, Omega-Praksis, Łódź

Węcławowicz G., 1975, Struktura przestrzeni społeczno-gospodarczej Warszawy $w$ latach 1931 i 1970 w świetle analizy czynnikowej, Prace Geograficzne IGiPZ PAN, 116, Wrocław-Warszawa-Kraków-Gdańsk

Węcławowicz G., 1988, Struktury społeczno-przestrzenne w miastach Polski, Wrocław-Warszawa-Kraków-Gdańsk

Węcławowicz G., 1992, Segregacja ludności wedtug poziomu wyksztatcenia w największych miastach Polski [w:] Wódz K., Czekaj K. (red.), Szkoła chicagowska w socjologii, Uniwersytet Śląski, PTS Sekcja Socjologii Miasta, Katowice-Warszawa, 185-222

Węcławowicz G., 2001, Przestrzeń ubóstwa - nowy czy stary wymiar zróżnicowania społeczno-przestrzennego w miastach Polski, Przegląd Geograficzny, 73(4), 315-334 
Węcławowicz G., 2002, From egalitarian cities in theory to non-egalitarian cities in practice: The changing social and spatial patterns in Polish cities [w:] Marcuse P., Van Kempen R. (red.), Of States and Cities: The Partitioning of Urban Space, Oxford University Press, Oxford, 183-199

Węcławowicz G., 2003, Społeczna geografia miasta, PWN, Warszawa

Węcławowicz G., 2008, Ludność z wyksztatceniem wyższym w strukturze spoteczno-przestrzennej Warszawy [w:] Warszawa Akademicka. Seminarium, Instytut Problemów Współczesnej Cywilizacji, Warszawa, 21-29

Węcławowicz, G., 1979, The Structure of Socio-economic Space in Warsaw in 1931 and 1970: A Study in Factorial Ecology [w:] French R. A., Hamilton F. E. I. (red.), The Socialist City: Spatial Structure and Urban Policy, John Willey \& Sons, Chichester, 387-424

Węcławowicz, G., 1998, Social Polarisation in Postsocialist Cities: Budapest, Prague and Warsaw [w:] Enyédi G. (red.), Social Change and Urban Restructuring in Central Europe, Akadémiai Kiadó, Budapest 55-66

Węclawowicz, G., 2004, Where the grass is greener in Poland: Regional and Intra-urban Inequalities [w:] Lee R., Smith D. M. (red.), Geographies and Moralities. International Perspectives on Development, Justice and Place, Blackwell, Londyn, 62-77

Wessel T., 2000, Social Polarization and Socio-economic Segregation in a Welfare State: The case of Oslo, Urban Studies, 37(10), 1947-1967

Wilson J. W., 1987, The Truly Disadvantaged: The Inner City, the Underclass, and Public Policy, University of Chicago Press, Chicago

Wong D., 2009., The modifiable areal unit problem (MAUP) [w:] Fortheringham A.S., Rogerson P. A. (red.), The SAGE Handbook of Spatial Analysis, SAGE, Londyn, 105-124

Zanon B., Marcińczak S., 2011, Land regimes, planning systems and urban dynamics in the European countries [w:] Tira M., van der Krabben E., Zanon B. (red.), Land Management for Urban Dynamics. Innovative methods and practices in a changing Europe, Maggioli, Mediolan, 27-46

Zborowski A., (red.), 2009, Społeczno-demograficzne uwarunkowania rewitalizacji miast w Polsce, Instytut Rozwoju Miast, Kraków

Zborowski A., 2005, Przemiany struktury spoteczno-przestrzennej regionu miejskiego $w$ okresie realnego socjalizmu $i$ transformacji ustrojowej (na 
przykładzie Krakowa), Instytut Geografii i Gospodarki Przestrzennej Uniwersytetu Jagiellońskiego, Kraków

Zorbaugh H.W., 1929/1976, The Gold Coast and the Slum. A sociological study of Chicago's near north side, University of Chicago Press, Chicago 
Spis treści

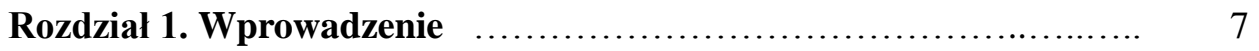

Rozdział 2. Segregacja społeczna jako przedmiot badań $\quad$ …............ 15

Podstawy teoretyczne ............................................. 15

Znaczenie i pomiar .............................................. 25

Rozdział 3. Segregacja społeczna w miastach epoki socjalizmu i po jej zakończeniu

Nierówności społeczne i segregacja przestrzenna w mieście socjalis-

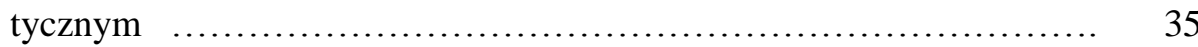

Podziały społeczne i przestrzenne w miastach postsocjalistycznych $\ldots \quad 44$

Rozdzial 4. Trzy stolice, trzy oblicza.

Ewolucja zróżnicowań społeczno-przestrzennych w Bukareszcie, Tallinie i Warszawie

Rozdział 5. Jak silnie podzielone?

Poziom segregacji spolecznej w Bukareszcie, Tallinie i Warszawie na początku XXI wieku

Rozdzial 6. „Zlote Wybrzeże” i „slums”.

Lokalne wzory segregacji społecznej w Bukareszcie, Tallinie i Warszawie po socjalizmie

Rozdział 7. „Paradoks” segregacji społecznej po socjalizmie. Podsumowanie i wnioski 